*als View/Frint Document Cover Sheet thes

This document was retrieved from the Boeing ISEARCH System.

Accession \#: D196054912

Document \#: SD-WM-TI-711

Title/Desc:

REMEDIATION \& CLEANOUT LEVELS FOR HANFORD SITE SST 


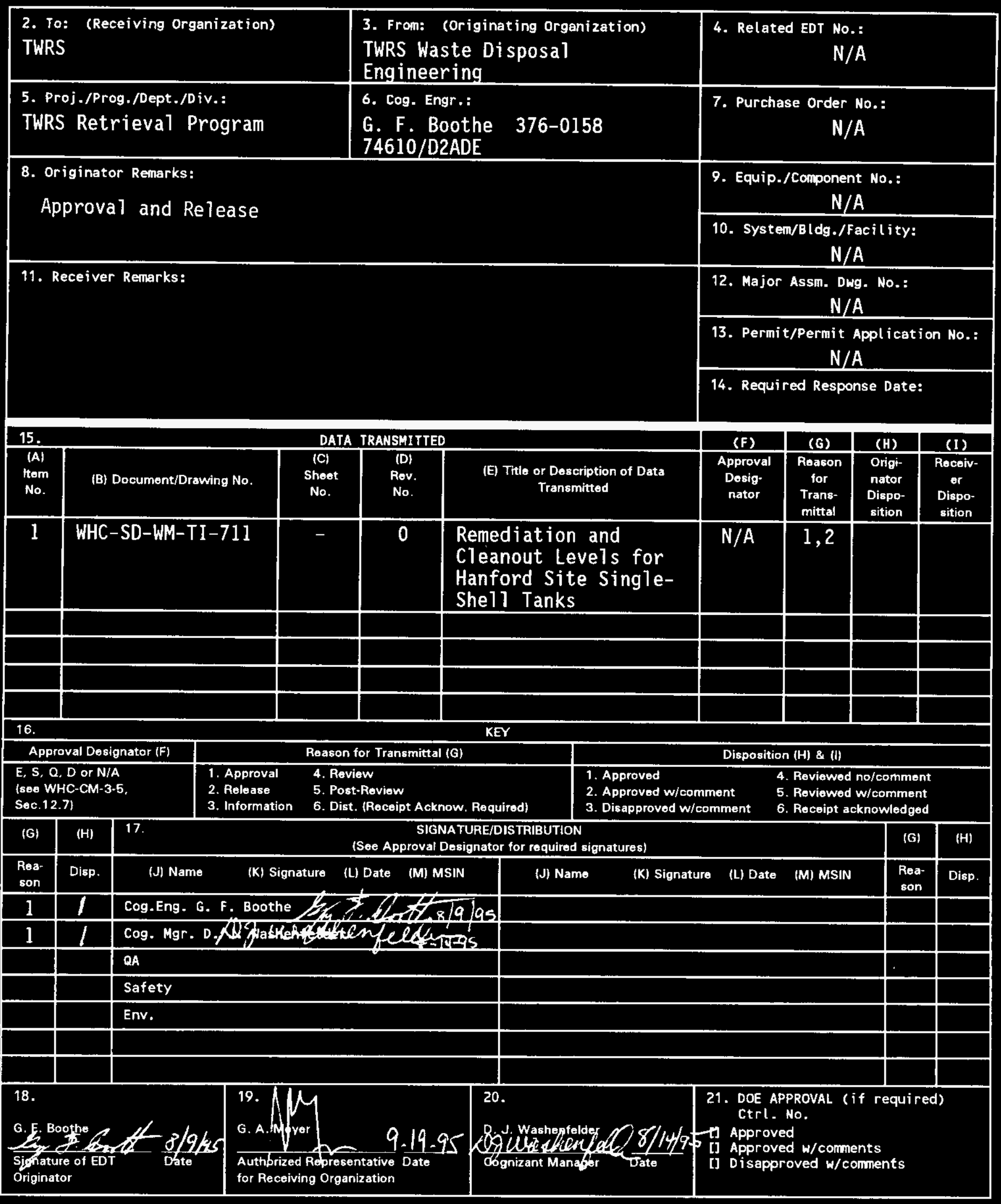




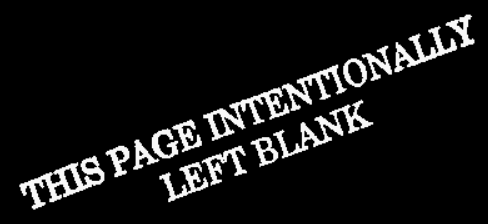




\section{RELEASE AUTHORIZATION}

Document Number: WHC-SD-WM-TI-711, Rev. 0

Document Title: $\quad$ Remediation and Cleanout Levels for Hanford Site Single-She 11 Tanks

Release Date: $\quad$ September 26, 1995

This document was reviewed following the procedures described in WHC-CM-3-4 and is:

APPROVED FOR PUBLIC RELEASE

WHC Information Release Administration Specialist:

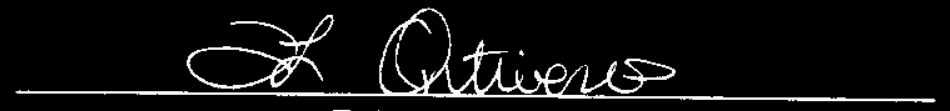

September 26, 1995

T.L. Ontiveros

TRADEMARK DISCLAIMER. Reference here in to any specific commercial product, process, or service by trade name, trademark, manufacturer, or otherwise, does not necessarily constitute or imply its endorsement, recommendation, or favoring by the United States Government or any agency thereof or its contractors or subcontractors.

This report has been reproduced from the best available copy. Available in paper copy. Printed in the United States of America. To obtain copies of this report, contact:

West inghouse Hanford Company - Document Control Services

P.0. Box 1970, Mailstop H6-08, Richland, WA 99352

Telephone: (509) 372-2420; Fax: (509) 376-4989 
D 
2. Titte

Remediation and Cleanout Levels for Hanford Site Single-Shell Tanks

5. Key Words

single-shel1 tanks

retrieval

hazard assessment
3. Number

WHC-SD-WM-TI-711

4. Rev No.
6. Author

Name: G. F. Boothe

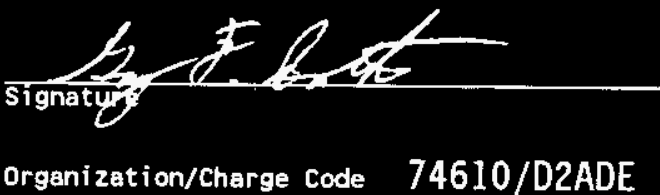

\section{Abstract}

The Hanford Federal Facility Agreement and Consent Order (Tri-Party Agreement) (Ecology et al. 1994), requires the retrieval of 99 percent of the Hanford Site single-shell tank (SST) waste. Retrieval of the waste requires the completion of saltwell pumping and then the sluicing of all 149 tanks, at a cost of over $\$ 3$ billion. The retrieved waste is to be processed and vitrified for ultimate disposal as glass.

This document shows that the intent of the Tri-Party Agreement can be met by sluicing the waste from only 86 tanks, after the completion of saltwell pumping. This partial retrieval option will result in a cost savings of over $\$ 600$ million in construction and operation alone, and will significantly reduce the volume of glass requiring disposal. 


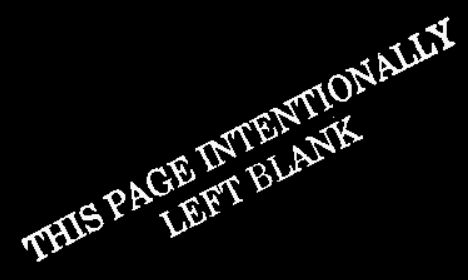


WHC-SD-WM-TI-711

Revision 0

\title{
REMEDIATION AND CLEANOUT LEVELS FOR HANFORD SITE SINGLE-SHELL TANKS
}

\author{
G. F. Boothe
}

September 1995

Westinghouse Hanford Company

Richland, Washington 
\& 
WHC-SD-WM-TI-711

Revision 0

\section{ACKNOWLEDGEMENTS}

Special thanks are extended to B. L. Trumpour of ICF Kaiser Hanford and C. J. Benar of Tank Waste Remediation System for their assistance in creating the graphics found throughout this document. 
<smiles>[CH]</smiles> 
WHC-SD-WM-TI-711

Revision 0

\section{EXECUTIVE SUMMARY}

The Hanford Federal Facility Agreement and Consent Order (Tri-Party Agreement) (Ecology et al. 1994), requires the retrieval of 99 percent of the Hanford Site single-shell tank (SST) waste. Retrieval of the waste requires the completion of saltwell pumping and then the sluicing of all 149 tanks, at an estimated cost of over $\$ 3$ billion for construction and operation. The retrieved waste is to be processed and vitrified for ultimate disposal.

This document provides a risk-based strategy for SST remediation. The strategy meets the intent of the Tri-Party Agreement by proposing retrieval of 99 percent of the wastes that pose a risk, rather than 99 percent of the waste volume. This document provides the following:

- Presents a methodology for evaluating hazards and risks from Hanford Site waste.

- Applies the methodology to SSTs and assigns hazard indices to the tanks. The hazard indices are based on potential doses to the public from tank waste.

- Concludes that 99 percent of the overall risk from SSTs resides in 86 tanks, which contain the following:

90 percent of the SST liquids

62 percent of the SST solids 
WHC-SD-WM-TI-711

Revision 0

100 percent of the transuranic tanks

99 percent of the long-lived alpha emitters

99 percent of the long-lived gamma emitters

90 percent of the mobile radionuclides

The majority of the hazardous chemical waste.

- Recommends that the Tri-Party Agreement stakeholders use the methodology of this document in re-evaluating criteria and milestones in the current agreement. This is in accord with the Secretary of Energy and Vice President Gore's initiative to reinvent government and apply new and innovative techniques.

Implementation of the risk-based strategy presented here would result in a cost savings of over $\$ 600$ million in construction and operation of SST retrieval systems, and would significantly reduce the volume of glass requiring disposal.

This document demonstrates that sluicing waste from 63 tanks, which represent only 1 percent of the overall risk, is not warranted. Of these 63 tanks, 43 contain no pumpable liquid, and are ready for closure immediately. After saltwell pumping is completed, the 20 other tanks would be available for closure. Removing these tanks from active storage status would result in additional cost savings. 


\section{WHC-SD-WM-TI-711}

\section{Revision 0}

It is recommended that consideration be given to the privatization of SST closure as soon as possible, so that cost savings can be quickly realized. 


\section{WHC-SD-WM-TI-711}

\section{Revision 0}

This page intentionally left blank. 
WHC-SD-WM-TI-711

Revision 0

\section{RESULTS AND CONCLUSIONS}

The Tri-Party Agreement requires the retrieval of 99 percent of the Hanford Site SST waste. Application of the 99 percent retrieval requirement will result in enormous costs without corresponding benefit in terms of risk reduction. Indiscriminate application of the criteria also will result in inappropriate levels of radioactive materials or chemicals being left in the tanks.

This document presents a risk-based retrieval strategy to deal with Hanford Site SSTs rather than the volume-based strategy of the Tri-Party Agreement. Implementation of the risk based strategy will meet the intent of the Tri-Party Agreement and will result in dramatic savings in construction and operational cost.

The hazards and risks from SSTs are not directly related to the volume of waste, nor the mass, nor even the curies of radioactive materials. This is because each radionuclide or chemical presents a different degree of hazard with respect to curie quantity, mass, or volume. For example, a gram of ${ }^{239} \mathrm{Pu}$ presents a significant hazard, whereas a gram of ${ }^{99} \mathrm{Tc}$ or nitrate is comparatively innocuous. To adequately describe and quantify the hazards presented by a SST, the radiological hazards must be normalized, and the chemical hazards must be normalized to the radiological hazards. This normalization can be achieved by using the concepts of Annual Limit on Intake (ALI) and ${ }^{126} \mathrm{Sn}$ equivalent curies. 


\section{WHC-SD-WM-TI-711}

\section{Revision 0}

The ALI is a standard measure of radiotoxicity. The ALI is simply the amount of any radionuclide ingested or inhaled that results in a dose of 5 rem, or 5 person-rem if a population is involved. The ALI for ${ }^{239} \mathrm{Pu}$ is extremely low $(0.006 u C i)$, while the ALI for tritium, for example, is relatively high $(80,000 \mathrm{uCi})$. The summation of the ALIs in a tank gives a true indication of the internal dose hazard presented by the tank, whether it is from ${ }^{239} \mathrm{Pu}$ or another radionuclide.

The number of ${ }^{126} \mathrm{~S} n$ equivalent curies normalizes the external radiation hazard from gamma emitters. For each ${ }^{126}$ Sn equivalent curie of gamma emitter deposited per $\mathrm{km}^{2}$ of soil, the annual dose to the public would be $0.05 \mathrm{rem}$. Since ${ }^{126} \mathrm{~S} \mathrm{n}$ is the only prevalent long-term gamma emitter in SST waste, the external radiation hazard is simply proportional to the curies of ${ }^{126} \mathrm{Sn}$.

The following three separate radiological normalizations are necessary:

1. Determine the amount of mobile ALIs contained in a tank. This is the normalized groundwater hazard from mobile radionuclides like ${ }^{99} T c$ and ${ }^{129} I$.

2. Determine the amount of nonmobile ALIs contained in a tank. This is the normalized inhalation hazard, primarily from the inhalation of resuspended ${ }^{239} \mathrm{Pu}$ and ${ }^{241} \mathrm{Am}$. 


\section{WHC-SD-WM-TI-711}

\section{Revision 0}

3. Determine the number of ${ }^{126} \mathrm{Sn}$ equivalent curies contained in a tank. This is the normalized external radiation hazard from gamma emitting radionuclides.

The normalized hazards can easily be related to SST constituents, as well as the major dose pathways. With the three normalized hazards determined, the level of hazard in a tank is known, where the hazard resides in the tank is known, and what part of the environment is threatened is known. It is not productive to combine the normalizations into a single hazard or risk index, as previous studies have done, because such an index cannot be related to all of these parameters. Furthermore, the three normalized hazards are amenable to cost/benefit comparisons relative to waste retrieval, whereas a single index is not.

Chemical hazards can be normalized to radiological hazards through their respective airborne control standards or drinking water standards. For example, if the drinking water standard for nitrate is $1.0 E-2 \mathrm{~g} / \mathrm{L}$ and the drinking water standard for ${ }^{239} \mathrm{Pu}$ is $2.0 \mathrm{E}-11 \mathrm{~g} / \mathrm{L}$, clearly ${ }^{239} \mathrm{Pu}$ is many times more hazardous to drink than nitrate on a mass basis. This does not mean that the risks presented by ${ }^{239} \mathrm{Pu}$ and nitrate in an SST are in ratio to their drinking water standards. Nitrate is much more mobile than plutonium, and therefore the risk of nitrate getting to the groundwater is much higher.

The determination of risk, as opposed to hazard, includes consideration of mobility, uptake fractions, dose, and many other factors. Figure 1 shows the relationship between radiological hazards in a tank and the risk these hazards present to the public. Once the 
WHC-SD-WM-TI-711

Revision 0

Figure 1. Tank Radiological Hazards and the Relationship to Risk.

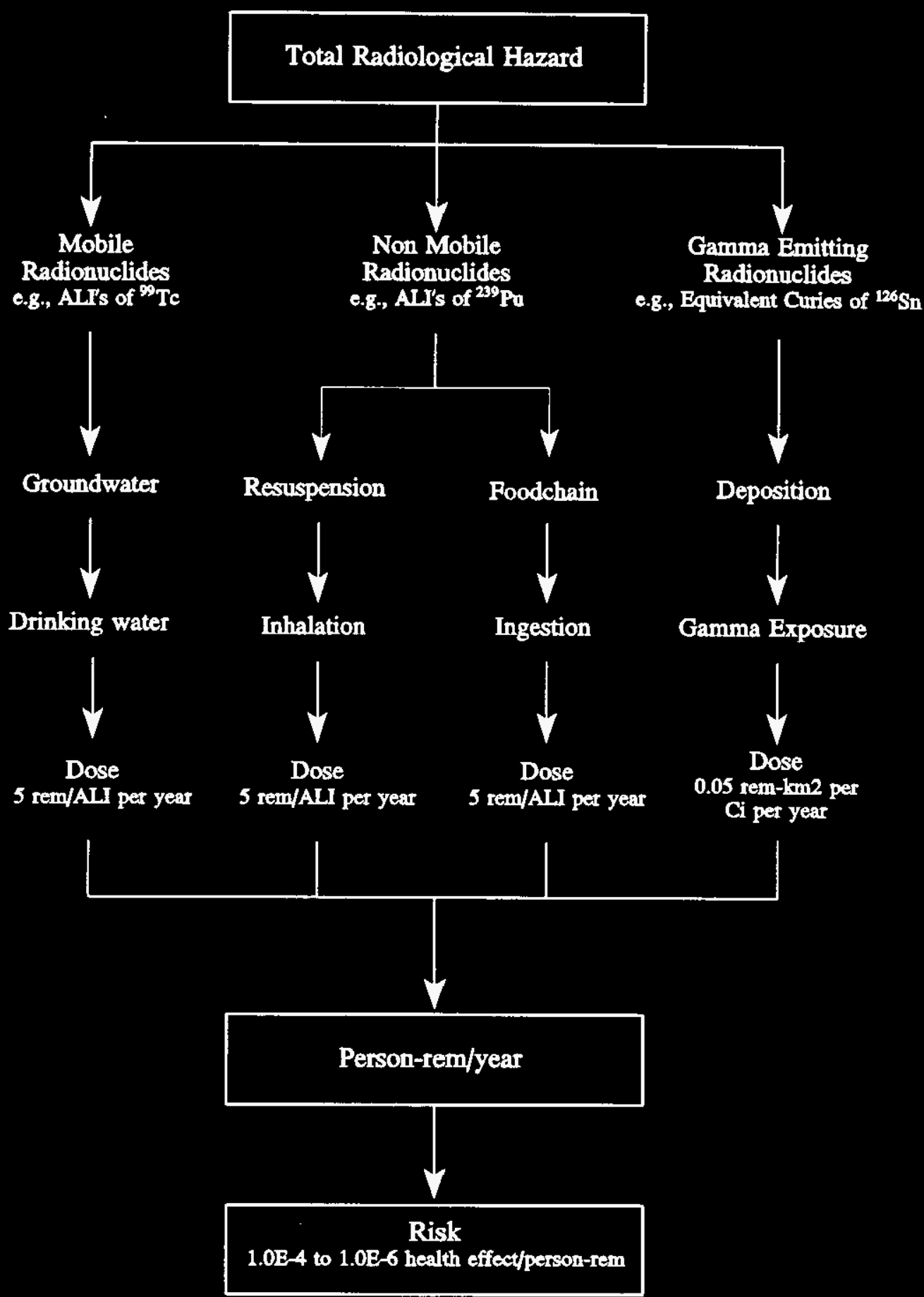

$\mathrm{ALI}=$ Annual Limit on Intake 


\section{WHC-SD-WM-TI-711}

\section{Revision 0}

hazards are normalized, the risks can be estimated. In general, the risks through various pathways of exposure are directly proportional to the normalized hazards for that pathway.

The ranking of the 149 Hanford Site SSTs using the three normalized hazards shows that most of the risks are contained in a small number of tanks. For example, 90 percent of the long-term inhalation hazard is contained in the solids of 41 tanks, while 90 percent of the groundwater hazard is contained in the liquid portion of 53 tanks. About 90 percent of the long-term gamma ray hazard is contained in 28 tanks. Figures 2 and 3 show the ranking of the tanks and the percent cumulative hazard for the mobile ALIs (groundwater hazard) and nonmobile ALIs (inhalation hazard), respectively. Figure 4 shows the ranking of tanks and the percent cumulative hazard for gamma emitting radionuclides $\left({ }^{26} \mathrm{Sn}\right)$. Complete tabular rankings of tanks and percent cumulative hazards with respect to mobile ALIs, nonmobile ALIs and gamma emitters are given in Appendices $F, G$, and $H$.

The percent cumulative hazard curves of Figures 2, 3, and 4 clearly show that the costs and benefits of tank waste retrieval can be optimized by carefully selecting tanks for remediation (sluicing), and leaving the waste in the other tanks as acceptable residuals for in situ disposal. The challenge in tank selection for remediation is to balance the reduction in hazard to the groundwater with the reduction of hazard to the rest of the environment, with due consideration to the cost and efficacy of retrieval. Also, all other factors pertinent to tank remediation must be considered, including leak status, transuranic (TRU) inventory, special chemical inventory, special safety or environmental concerns, and regulatory issues. 
Revision 0

Figure 2. Ranking of Single-Shell Tanks in Accordance with Nonmobile Annual Level of Inputs.

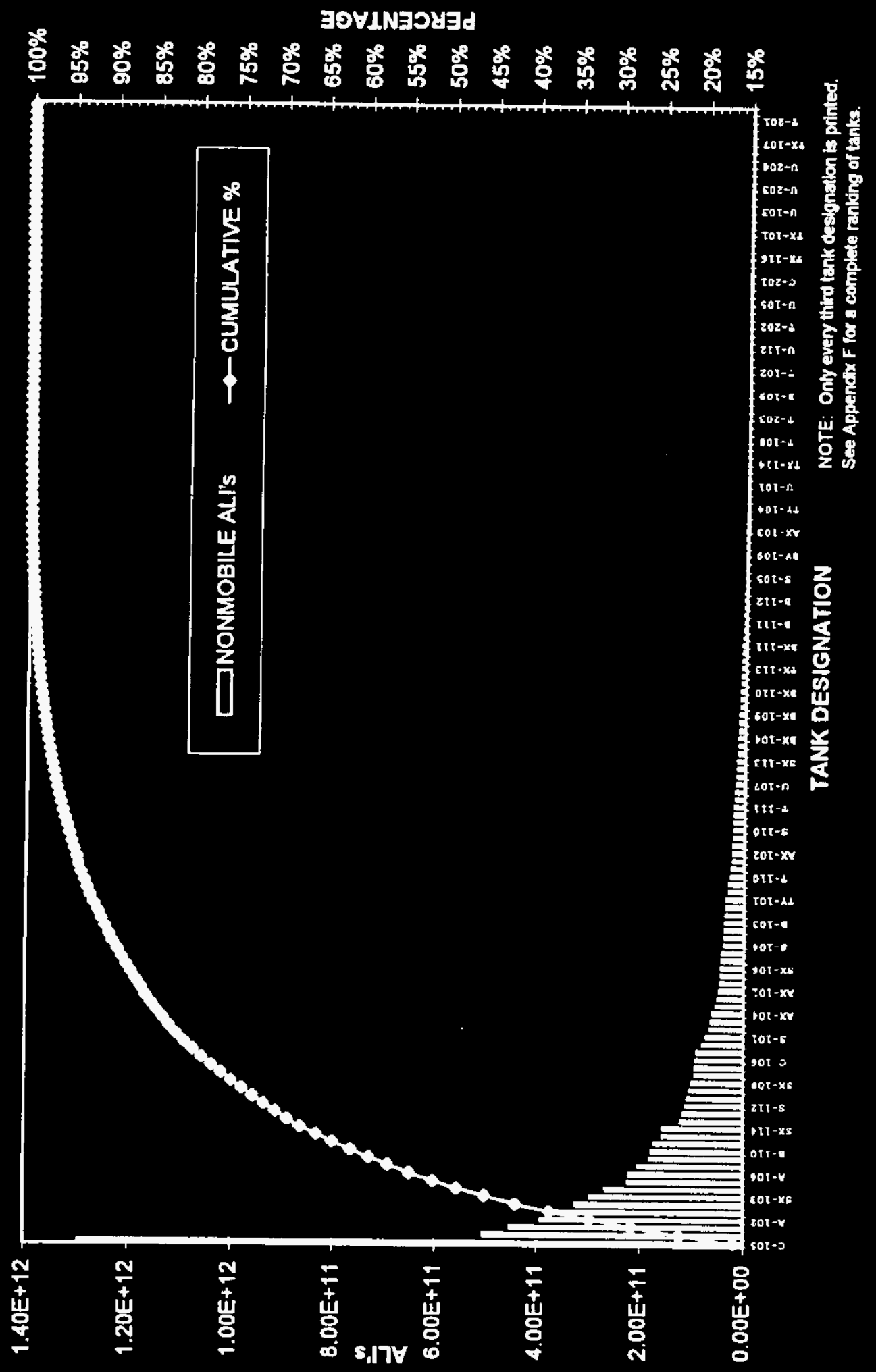


Figure 3. Ranking of Single-Shell Tanks in Accordance with Mobile Annual Level of Inputs.

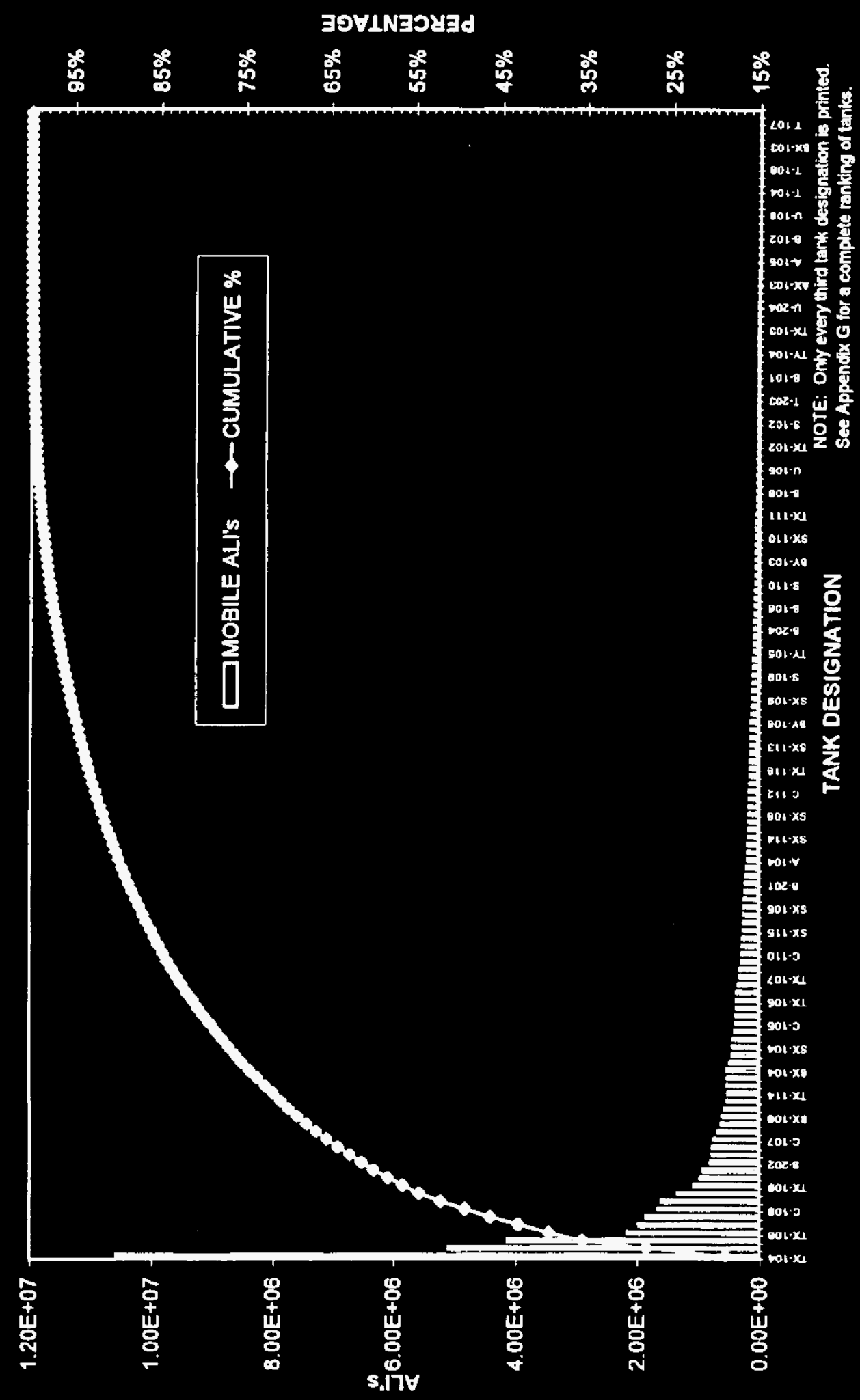


Figure 4. Ranking of Single-Shell Tanks in Accordance with ${ }^{126}$ Sn Curies.

\section{בอYLNE989d}

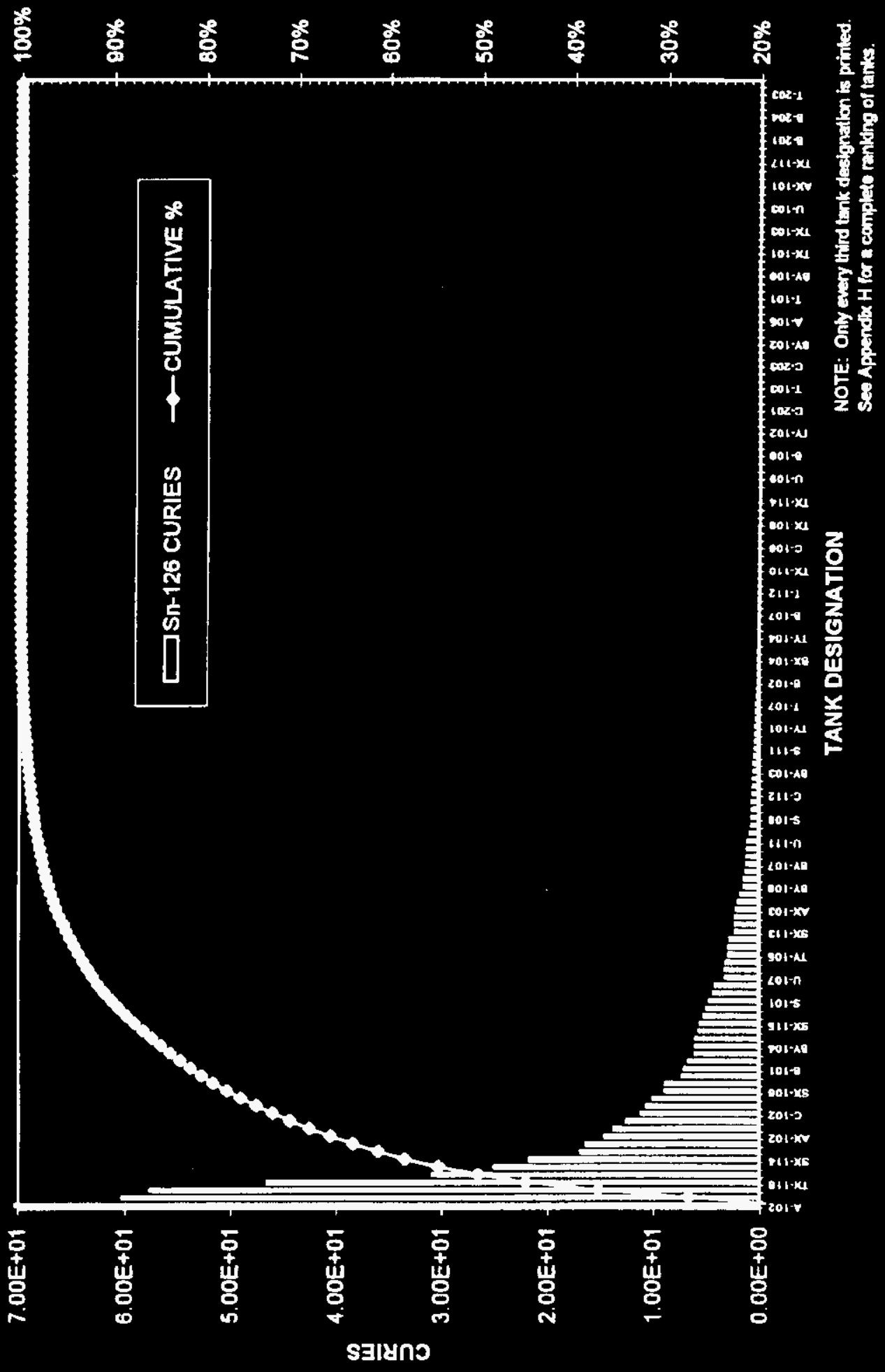




\section{WHC-SD-WM-TI-711}

Revision 0

Four options for tank remediation and overall cleanout levels are presented in Section 5.2, including a preferred option (Option 3). These options were designed to give the most hazard reduction for the fewest tanks selected for remediation. The four options are depicted in Figures 5 through 8, and are briefly described as follows:

Option 1. In this option, the 41 tanks containing the highest nonmobile ALIs are selected for remediation. The waste in all other tanks would be left as acceptable residuals. The justification for this option is the fact that most of the hazard and risk and most of the TRU reside in the nonmobile ALIs. About 90 percent of the inhalation hazard, 27 percent of the groundwater hazard and 90 percent of the external radiation hazard is eliminated with this option. It would be appropriate to propose that this option be adopted initially, and then when budget allows, other tanks could be worked off. The cost per million ALI (MALI) retrieved (assuming $\$ 20$ million per tank) is $\$ 111.53$.

Option 2. In this option, 71 tanks containing the highest nonmobile ALIs (99 percent) are selected for remediation. The groundwater hazard is reduced by 45 percent and the gamma hazard is reduced by 99 percent. The cost per MALI retrieved is $\$ 180.70$. 
WHC-SD-WM-TI-711

Revision 0

Figure 5. Hazard Reduction From Remediation of 41 Single-Shell Tanks. (Option \#1, Section 5.2)

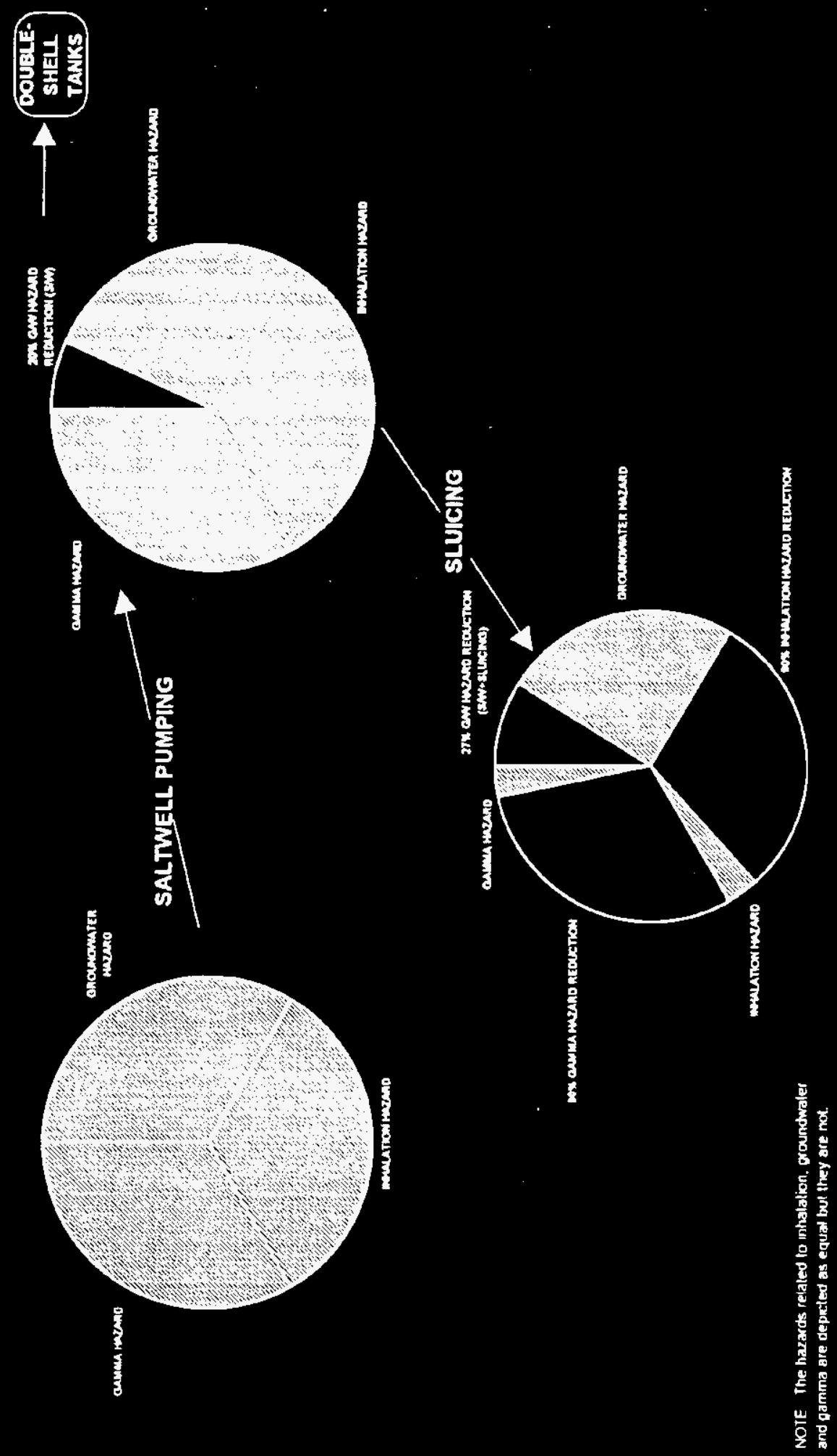


WHC-SD-WM-TI-711

Revision 0

Figure 6. Hazard Reduction From Remediation of

71 Single-Shell Tanks. (Option \#2, Section 5.2)

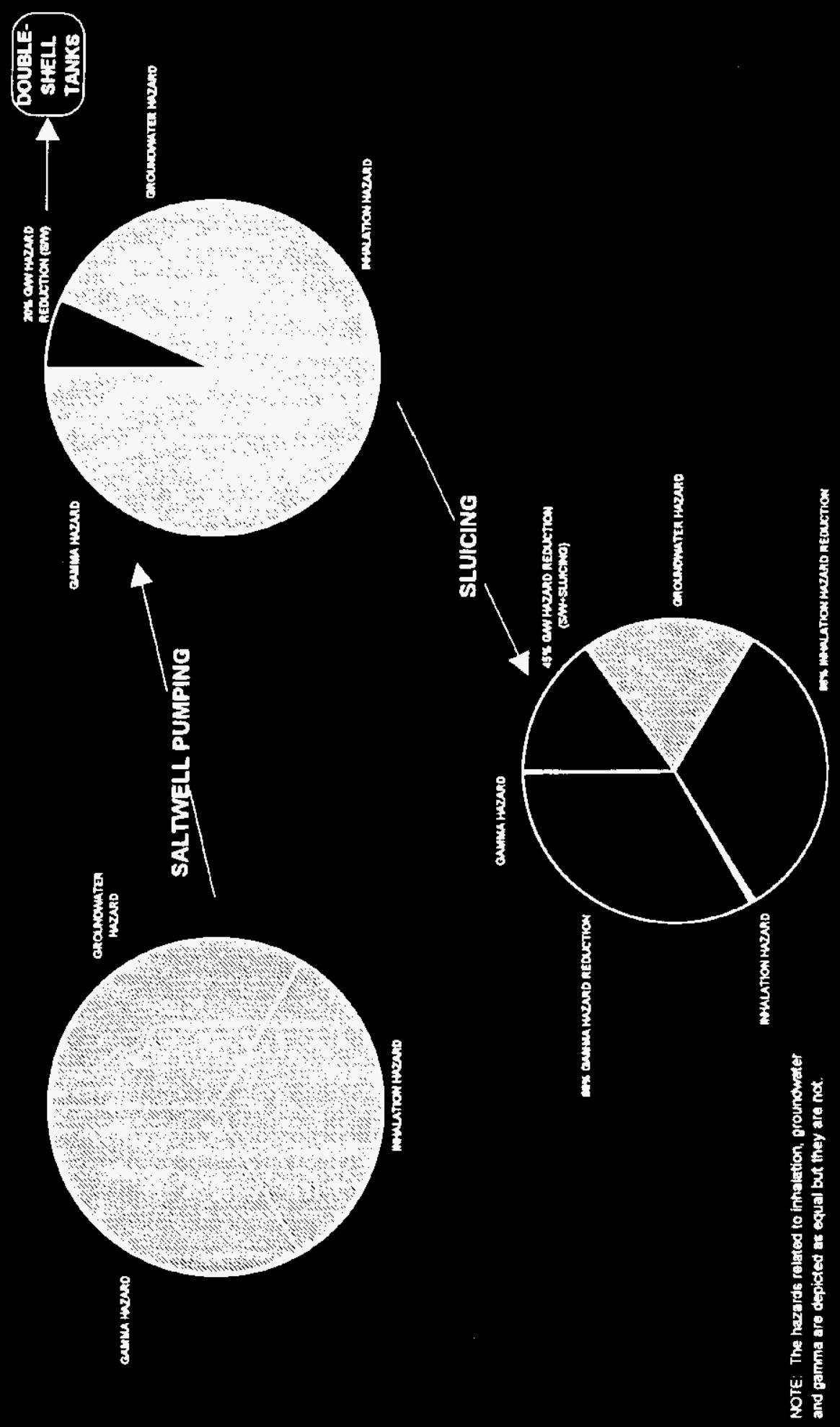


Figure 7. Hazard Reduction From Remediation of 86 Single-Shell Tanks. (Option \#3, Section 5.2)

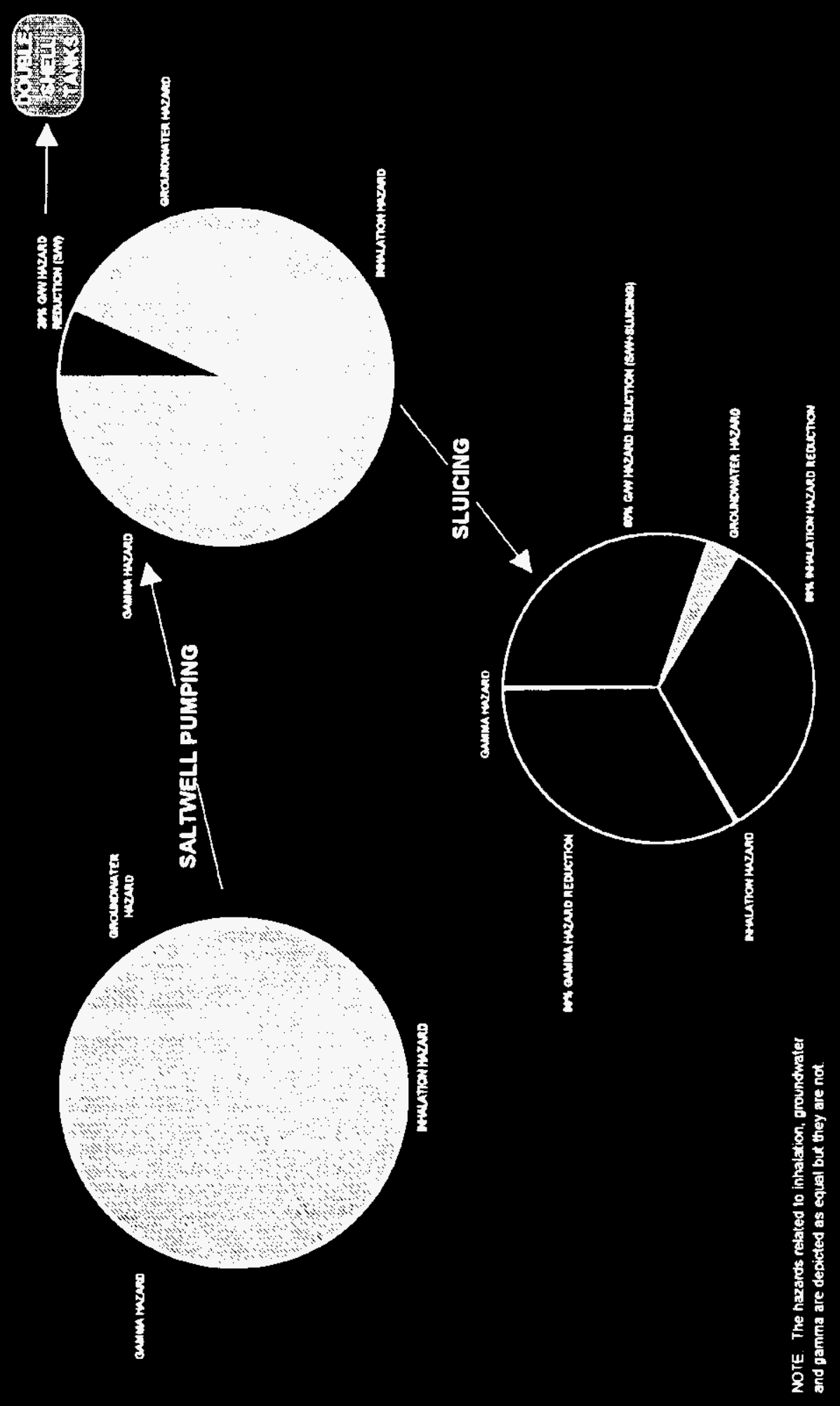


WHC-SD-WM-TI-711

Revision 0

Figure 8. Hazard Reduction From Remediation of

96 Single-Shell Tanks. (Option \#4, Section 5.2)

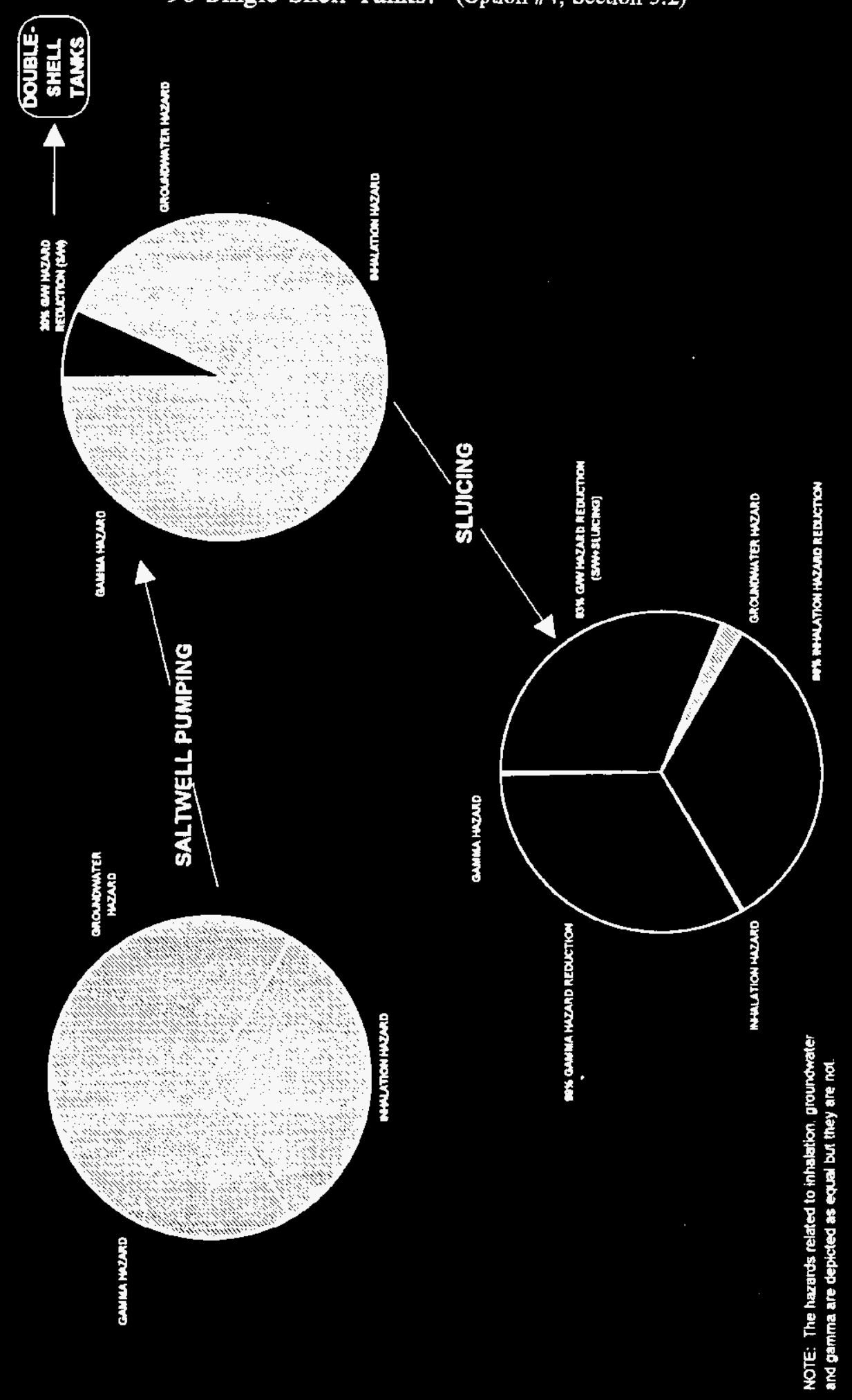

xix 
WHC-SD-WM-TI-711

Revision 0

Option 3. In addition to the 71 tanks of Option 2, 15 additional tanks are selected for remediation to remove more mobile ALIs. The total number of tanks selected for remediation is 86. This option retrieves 99 percent of the inhalation hazard, 90 percent of the groundwater hazard, and 99 percent of the gamma hazard. The majority of hazardous chemicals are also retrieved (90 percent of the predominant soluble hazardous chemicals and 98 percent of the insoluble hazardous chemicals). Through saltwell pumping and sluicing, 62 percent of the solids and 90 percent of the liquids currently in SSTs are removed. The cost per MALI retrieved is $\$ 217.59$. Since most of the long-term risk is through the inhalation pathway, this option reduces the overall risk by about 99 percent. With this option, adding tanks to the retrieval list would reduce the hazard by less than 0.1 percent per tank on the average. This is one of the reasons why this option is the preferred option.

Option 4. In this option, 96 tanks are selected for remediation to achieve an inhalation hazard reduction of 99 percent, a groundwater hazard reduction of 93 percent, a 99 percent reduction in the gamma hazard, and additional reduction in soluble and insoluble chemical hazards. While little is gained in hazard reduction, the cost per MALI retrieved goes up to $\$ 251.99$. 
WHC-SD-WM-TI-711

Revision 0

Figure 9 summarizes the results of the four options with respect to risk reduction and the price of tank remediation in terms of cost/MALI retrieved. Below Option 1, costs of retrieving a MALI are initially very low, but increase with each tank selected for

remediation. Above Option 2, costs/MALI retrieved continue to rise sharply, but with only a small corresponding risk reduction.

Table 1 compares the four partial retrieval options with the baseline case where all 149 tanks are selected for remediation. The table shows that the baseline case achieves very little added reduction in hazard (e.g., 0.58 percent for inhalation) over the preferred option, yet the cost of the baseline case is considerably more (170 percent).

Table 1. Comparison of Partial Retrieval Options With Baseline Retrieval

\begin{tabular}{|l|c|c|c|c|c|}
\hline & $\begin{array}{c}\text { Number of } \\
\text { tanks } \\
\text { retrieved }\end{array}$ & $\begin{array}{c}\text { Percent } \\
\text { inhalation } \\
\text { hazard } \\
\text { reduction }\end{array}$ & $\begin{array}{c}\text { Percent } \\
\text { groundwater } \\
\text { hazard } \\
\text { reduction }\end{array}$ & $\begin{array}{c}\text { Percent } \\
\text { gamma } \\
\text { hazard } \\
\text { reduction }\end{array}$ & $\begin{array}{c}\text { Cost of } \\
\text { MALI } \\
\text { retrieved \$a }\end{array}$ \\
\hline Option 1 & 41 & 90.19 & 26.55 & 89.87 & 111.53 \\
\hline Option 2 & 71 & 98.23 & 45.32 & 98.76 & 180.70 \\
\hline Option 3 & 86 & 98.81 & 90.38 & 98.87 & 217.59 \\
\hline Option 4 & 96 & 99.07 & 92.82 & 99.01 & 251.99 \\
\hline Baseline $^{\mathrm{b}}$ & 149 & 99.39 & 97.29 & 99.33 & 370.22 \\
\hline
\end{tabular}

MALI $=$ Million Annual Limit on Intake

aAssumes each tank selected for remediation costs an average of $\$ 20$ million.

${ }^{\mathrm{b}}$ The baseline case assumes all tanks are selected for remediation and that $5 \mathrm{~m}^{3}$ of liquid waste and $5 \mathrm{~m}^{3}$ of solid waste are left in each 200 series tank, and one tenth of these amounts are left in the 100 series tanks. 
Figure 9. Cost per Million Annual Level of Inputs Retrieved versus Hazard Reduction for Single-Shell Tanks.

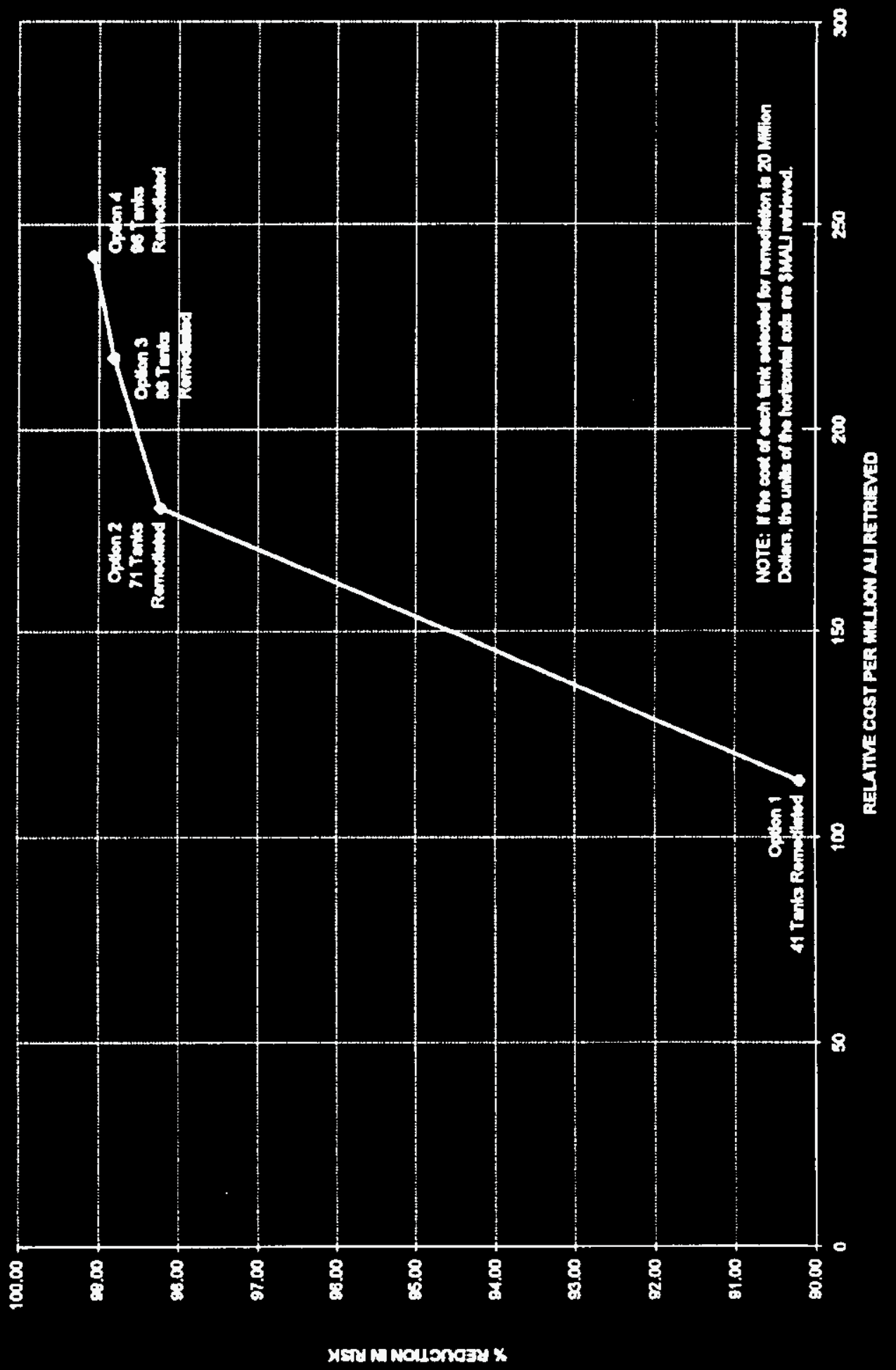




\section{WHC-SD-WM-TI-711}

\section{Revision 0}

Option 3 proposes the remediation of 86 specific SSTs, leaving the waste in the other 63 tanks as acceptable residuals, after saltwell pumping. This option is the preferred option for the following reasons:

1. Approximately 99 percent of the overall risk is mitigated.

2. The 99 percent risk reduction meets the objectives of the Tri-Party Agreement criteria.

3. After the remediation of the tanks selected in Option 3, the cost per MALI retrieved continues to rise sharply, with no discernable reduction in risk.

4. The TRU tanks are reduced to non-TRU.

5. Tanks containing high levels of hazardous chemicals are selected for remediation.

There are 43 tanks that were not selected for sluicing under the preferred option that contain no pumpable liquids and less than 1 percent of the total risk from SSTs. These 43 tanks are ready for permanent disposal immediately. After saltwell pumping, an additional 20 tanks will contain acceptable residuals and will be available for filling and permanent disposal. 


\section{WHC-SD-WM-TI-711}

Revision 0

By adopting the retrieval strategy and cleanout criteria presented in this document, the current risks from SSTs will be reduced to levels consistent with the intent of the Tri-Party Agreement at minimum cost. By implementing the recommendations of this document as opposed to waste volume reduction goals, considerable cost savings will be realized in retrieval and disposal, and cleanup goals can be accelerated. 
WHC-SD-WM-TI-711

Revision 0

TABLE OF CONTENTS

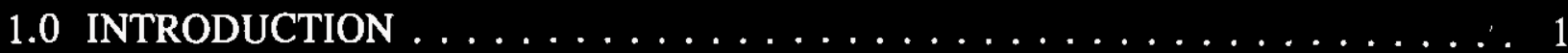

1.1 PURPOSE OF DOCUMENT $\ldots \ldots \ldots \ldots \ldots \ldots \ldots \ldots \ldots$

1.2 CURRENT TRI-PARTY AGREEMENT CRITERIA AND

IMPLICATIONS $\ldots \ldots \ldots \ldots \ldots \ldots \ldots \ldots \ldots \ldots$

1.3 SCOPE AND LIMITATIONS OF PROPOSED STANDARDS . . . . . . . 2

2.0 HAZARD DETERMINATION $\ldots \ldots \ldots \ldots \ldots \ldots \ldots \ldots \ldots$

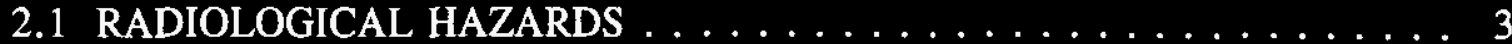

2.1.1 Internal Dose . . . . . . . . . . . . . . . . 3

2.1.2 External Dose . . . . . . . . . . . . . . . 4

2.2 INHERENT CHEMICAL HAZARDS $\ldots \ldots \ldots \ldots \ldots \ldots \ldots \ldots$

2.3 RELATIVE HAZARDS OF SINGLE-SHELL TANKS . . . . . . . . 6

3.0 HAZARDS VERSUS RISKS . . . . . . . . . . . . . . . . 9

3.1 HAZARDS AS DETERMINED BY ALI $\ldots \ldots \ldots \ldots \ldots \ldots \ldots$

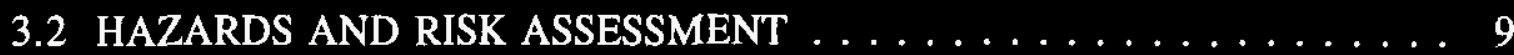

3.3 BOUNDING CUMULATIVE DOSES FROM MOBILE AND

NONMOBILE RADIONUCLIDES $\ldots \ldots \ldots \ldots \ldots \ldots \ldots$

4.0 REGULATORY ISSUES AND CONSTRAINTS . . . . . . . . . . . . 13

4.1 WASTE ACCEPTANCE CRITERIA FOR SHALLOW LAND BURIAL . . . 13

4.2 HAZARDOUS WASTE DISPOSAL RESTRICTIONS . . . . . . . . . . 13

5.0 PROPOSED REMEDIATION AND CLEANOUT STANDARDS $\ldots \ldots \ldots \ldots$

5.1 OPTIONS FOR TANK REMEDIATION AND CLEANOUT $\ldots \ldots \ldots 16$

6.0 REFERENCES . . . . . . . . . . . . . . . . . . 21

APPENDIXES

A - ALIS AND DOSE FACTORS FOR PREDOMINANT TANK WASTE RADIONUCLIDES . . . . . . . . . . . . . . . . A-1

B - PREDOMINANT CHEMICALS IN SINGLE-SHELL TANKS $\ldots \ldots \ldots \ldots$. . .

C - GROUNDWATER QUALITY STANDARDS AND AIRBORNE CONTROL LEVELS OF PREDOMINANT RADIONUCLIDES AND CHEMICALS IN SINGLE-SHELL TANKS . . . . . . . . . . . . . . . . C-1 
D - CURRENT WASTE VOLUMES AND RADIONUCLIDE INVENTORIES FOR HANFORD SINGLE-SHELL TANKS $\ldots \ldots \ldots \ldots \ldots$. . . . .

D.1. INSOLUBLE CHEMICAL INVENTORIES AND HAZARD INDEX FOR SINGLE-SHELL TANKS . . . . . . . . . . . . . D-8

D.2. SOLUBLE CHEMICAL INVENTORIES AND HAZARD INDEX FOR SINGLE-SHELL TANKS $\ldots \ldots \ldots \ldots \ldots \ldots \ldots \ldots$ D-13

E - CURRENT WASTE VOLUMES AND RADIOLOGICAL PARAMETERS FOR HANFORD SINGLE-SHELL TANKS $\ldots \ldots \ldots \ldots \ldots \ldots \ldots$ E-1

F - RANKING OF SINGLE-SHELL TANKS BY NONMOBILE ALIs;

CUMULATIVE PERCENT OF NONMOBILE ALIs . . . . . . . . . . F F-1

F.1. RANKING OF SINGLE-SHELL TANKS BY INSOLUBLE CHEMICAL HAZARD . . . . . . . . . . . . . . F-7

F.2. RANKING OF SINGLE-SHELL TANKS BY SOLUBLE CHEMICAL HAZARDS . . . . . . . . . . . . . . F-11

G - RANKING OF SINGLE-SHELL TANKS BY MOBILE ALIs; CUMULATIVE PERCENT OF MOBILE ALIs . . . . . . . . . . . . . . . . G-1

H - RANKING OF SINGLE-SHELL TANKS BY ${ }^{126}$ Sn CURIES; CUMULATIVE PERCENT OF ${ }^{126}$ Sn CURIES $\ldots \ldots \ldots \ldots \ldots \ldots \ldots \ldots \ldots$. . . . . . .

I - CALCULATION OF BOUNDING CUMULATIVE PUBLIC DOSE (PERSON-REM) FOR SINGLE-SHELL TANKS $\ldots \ldots \ldots \ldots \ldots \ldots$. . . . .

$\mathrm{J}$ - SINGLE-SHELL TANK REMEDIATION AND HAZARD REDUCTION $\ldots \ldots$ J-1 
WHC-SD-WM-TI-711

Revision 0

\section{LIST OF FIGURES}

1. Tank Radiological Hazards and the Relationship to Risk $\ldots \ldots \ldots \ldots \ldots$

2. Ranking of Single-Shell Tanks in Accordance with Nonmobile Annual Level of Inputs $\ldots \ldots \ldots \ldots \ldots \ldots \ldots \ldots \ldots \ldots \ldots \ldots \ldots \ldots \ldots \ldots \ldots \ldots$

3. Ranking of Single-Shell Tanks in Accordance with Mobile Annual Level of Inputs . . xiii

4. Ranking of Single-Shell Tanks in Accordance with ${ }^{126}$ Sn Curies $\ldots \ldots \ldots \ldots$ xiv

5. Hazard Reduction From Remediation of 41 Single-Shell Tanks $\ldots \ldots \ldots$. . . xvi

6. Hazard Reduction From Remediation of 71 Single-Shell Tanks $\ldots \ldots \ldots$. . . xvii

7. Hazard Reduction From Remediation of 86 Single-Shell Tanks $\ldots \ldots \ldots$. . . xviii

8. Hazard Reduction From Remediation of 96 Single-Shell Tanks . . . . . . . . . . xix

9. Cost per Million Annual Level of Inputs Retrieved versus Hazard Reduction for Single-Shell Tanks. . . . . . . . . . . . . . . . . xxii

\section{LIST OF TABLES}

1. Comparison of Partial Retrieval Options With Baseline Retrieval $\ldots \ldots \ldots \ldots$ xxi

2. Tanks Not Selected for Sluicing Under Preferred Option. . . . . . . . . 18 


\section{WHC-SD-WM-TI-711}

Revision 0

\section{LIST OF TERMS}

$\begin{array}{ll}\text { AEA } & \text { Atomic Energy Act } \\ \text { ALARA } & \text { As low as reasonably achievable } \\ \text { ALI } & \text { Annual Limit on Intake } \\ \text { DF } & \text { Dispersion factor } \\ \text { DOE-RL } & \text { U.S. Department of Energy-Richland Operations Office } \\ \text { EF } & \text { Escape fraction } \\ \text { EPA } & \text { U.S. Environmental Protection Agency } \\ \text { HLW } & \text { High-level waste } \\ \text { LLW } & \text { Low-level waste } \\ \text { MALI } & \text { Million annual limit on intake } \\ \text { PNL } & \text { Pacific Northwest Laboratory } \\ \text { RCRA } & \text { Resource Conservation and Recovery Act of 1976 } \\ \text { SST } & \text { Single-shell tank } \\ \text { TLV } & \text { Threshold limit value } \\ \text { TRAC } & \text { Track Radioactive Components } \\ \text { Tri-Party } & \text { Hanford Federal Facility Agreement and Consent Order } \\ \text { Agreement } & \\ \text { TRU } & \text { Transuranic } \\ \text { UF } & \text { Uptake fraction } \\ \text { WHC } & \text { Westinghouse Hanford Company }\end{array}$


WHC-SD-WM-TI-711

Revision 0

\section{REMEDIATION AND CLEANOUT LEVELS FOR HANFORD SITE SINGLE-SHIELL TANKS}

\subsection{INTRODUCTION}

Due to the shrinking Hanford Site budget, it is imperative that retrieval of Hanford Site single-shell tank (SST) waste be cost effective and commensurate with mitigated risks. One issue concerning this is the determination of acceptable levels of residual radioactivity and chemical wastes (cleanout levels) in Hanford Site tanks after efforts have been made to retrieve the waste for vitrification and ultimate disposal.

\subsection{PURPOSE OF DOCUMENT}

This document describes a hazard-based method of deciding tank remediation and overall cleanout levels for SSTs. Several options for remediation and cleanout levels are presented, including a preferred option. It is recommended that the preferred option for remediation and cleanout levels be included in the closure plans for SST farms and that this option be negotiated with the Hanford Federal Facility Agreement and Consent Order (Tri-Party Agreement) (Ecology et al. 1994) stakeholders. Application of hazard-based cleanout levels rather than the arbitrary levels currently specified in the Tri-Party Agreement should result in considerable cost savings.

\subsection{CURRENT TRI-PARTY AGREEMENT CRITERIA AND IMPLICATIONS}

The Tri-Party Agreement currently specifies that 99 percent of tank waste shall be retrieved. The latest milestone (M-45-00) of the Tri-Party Agreement specifies a waste volume limit of $10 \mathrm{~m}^{3}\left(360 \mathrm{ft}^{3}\right)$ for 100 series tanks and $1 \mathrm{~m}^{3}\left(36 \mathrm{ft}^{3}\right)$ for 200 series tanks (WHC 1994a). These numbers were derived by allocating 1 percent of the total SST waste volume to each tank, according to the size of the tank. These retrieval criteria are not hazard-based or risk-based. Consequently, for some tanks the criteria may result in the expenditure of a great deal of time and money with no commensurate mitigation of hazard or risk. For other tanks, adherence to the Tri-Party Agreement criteria may result in excessive amounts of radioactive or chemical waste being left in the tanks.

Rather than applying the 99 percent removal criteria and the arbitrary waste volume limits, the acceptable residual levels of radioactive and chemical wastes in tanks should be based on the hazards these residuals represent. The level of effort and cost of waste retrieval should be determined by the risk represented by the waste. The residual waste must also meet the waste acceptance criteria specified in Hanford Solid Waste Acceptance Criteria, WHC-EP-0063-3 (Willis and Triner 1991). The criteria in the WHC-EP-0063-3 manual are 
based on the performance assessment for shallow land burial, and include a restriction on the burial of transuranic (TRU) radionuclides (i.e., TRU $>100 \mathrm{nCi} / \mathrm{g}$ ). The WHC-EP-0063-3 criteria are derived from DOE Order 5820.2A, Radioactive Waste Management (DOE 1988) and WAC 173-303, Dangerous Waste Regulations (Ecology et al. 1991).

\subsection{SCOPE AND LMITATIONS OF PROPOSED STANDARDS}

The overall cleanout levels proposed here are based on the inherent hazards and related environmental risks of the residual radioactivity and chemicals within SSTs. No consideration was given to occupational risks, such as the potential for tank explosions, radiation doses incurred during retrieval, radiation doses or other hazards associated with making glass, industrial-type accidents during waste handling, etc. These risks are described to some extent by PNL (1995) and by MacFarlane (1994 and 1995).

Inherent hazards mean the innate hazards presented by the radiological and chemical constituents of the tanks, irrespective of assumed dose pathways, assumed mobility, or assumed public exposure. Environmental risks mean the risks due to the potential migration of radioactive materials or chemicals into the environment and the consequent, potential public dose. This document focuses on the hazards presented by the SSTs. However, bounding cumulative public doses are calculated and discussed below, solely for the purpose of giving a perspective on the related risks from SST hazards. 
WHC-SD-WM-TI-711

Revision 0

\subsection{HAZARD DETERMINATION}

This section discusses the inherent radiological and chemical hazards of SSTs.

\subsection{RADIOLOGICAL HAZARDS}

The radioactive materials contained in SSTs present the following two types of radiological hazards:

1. Internal dose hazards through inhalation and ingestion

2. External dose hazards from gamma emitters.

The two principal dose pathways are groundwater (drinking water, irrigation) and terrestrial (resuspension, food-chain). For the groundwater pathway, most of the dose would be caused through drinking water. For the terrestrial pathway, most of the dose is through inhalation of radioactive materials.

\subsubsection{Internal Dose}

The inherent level of internal dose hazard presented by radioactive materials in a given tank can be precisely quantified in terms of the number of Annual Limits On Intake (ALI) that are in the tank. The ALI is simply the amount of radioactive material ingested or inhaled that results in a dose of 5 rem, or 5 person-rem if the exposure is to a population rather than to an individual. The ALI for radionuclides such as ${ }^{239} \mathrm{Pu}$ is extremely low (4.8E-9 Ci), while the ALI for relatively innocuous radionuclides like ${ }^{99} \mathrm{Tc}$ is much higher (7.2E-4 Ci). The ALIs for the predominant radionuclides in Hanford Site waste tanks are listed in Appendix A. As the appendix shows, the drivers with respect to long-term (> 300 years) internal dose and risk are ${ }^{239} \mathrm{Pu} /{ }^{240} \mathrm{Pu},{ }^{241} \mathrm{Am}$, uranium, ${ }^{79} \mathrm{Se},{ }^{99} \mathrm{Tc}$ and ${ }^{129} \mathrm{I}$. The number of ALIs of these radionuclides can be taken as the indices of the long-term internal radiological hazards presented by the waste.

Any hypothetical internal public dose from tank waste is directly proportional to the number of ALIs that reaches the public. In this document, two types of ALIs in the liquid and solid fractions of the tank wastes are determined: mobile ALIs and nonmobile ALIs. With these two types of ALIs, the inherent internal dose hazards and risks of SSTs are thoroughly characterized.

Mobile ALIs in a tank are represented by the summation of the number of ${ }^{79} \mathrm{Se},{ }^{99} \mathrm{Tc}$, ${ }^{129} \mathrm{I}$ and uranium ALIs in the tank. These are the predominant radionuclides that have high mobilities in the environment. That is, they migrate readily through the vadose zone. The radionuclide ${ }^{14} \mathrm{C}$ is also mobile and long lived, but is of lesser significance. For purposes of 


\section{Revision 0}

simplicity and conservatism, it is assumed that all chemical species of these radionuclides have the same mobility (i.e., they are not retarded in migrating to the groundwater). Therefore, the number of mobile ALIs is a measure of the ultimate threat to the groundwater.

Nonmobile ALIs in a tank are represented by the summation of the number of ${ }^{239 / 240} \mathrm{Pu}$ and ${ }^{241} \mathrm{Am}$ ALIs in the solid fraction of the waste, including salt cake and sludge. The solid ALIs are the principal internal dose threat in the terrestrial environment. Over a long period, pathways to the environment may form in the SST disposal system. These pathways could include cracks in the barriers (soil cover and tank wall), intrusions by plants or animals, and wind or water erosion. Ultimately, small amounts of radioactive material could be brought to the surface, dry out, become airborne (suspended), and migrate off-site. Although there are a variety of long-term terrestrial internal dose pathways, the dominant one for SSTs would be the inhalation of resuspended ${ }^{239} \mathrm{Pu}$ and ${ }^{241} \mathrm{Am}$. Consequently, the predominate hazard from SSTs is represented by the number of nonmobile ALIs the tanks contain.

\subsubsection{External Dose}

Once the ${ }^{137} \mathrm{Cs}$ in SST waste has decayed away, there are not many gamma emitters left to cause external dose. A notable exception, as shown in Appendix A, and the bounding radionuclide with respect to external radiation, is ${ }^{126} \mathrm{Sn}$ (Schmittroth 1995 and Rittmann 1994). This radionuclide has a half-life of 100,000 years. The radiological hazard from ${ }^{126} \mathrm{Sn}$ is not easily related to the number of ALIs, since the dose is external rather than internal. The dose from gamma emitters can be normalized to equivalent curies of ${ }^{126} \mathrm{Sn}$, which has a dose factor of 0.05 rem- $\mathrm{km}^{2} / \mathrm{Ci}$-year. However, since ${ }^{126} \mathrm{Sn}$ is the only prevalent long-term gamma emitter, the long-term, external dose hazards from SSTs is assumed to be proportional to the total Curies of ${ }^{126} \mathrm{Sn}$.

Some thought was given regarding the inclusion of ${ }^{90} \mathrm{Sr}$ into the ALI determinations and ${ }^{137} \mathrm{Cs}$ into the external hazard considerations. At the present time, ${ }^{137} \mathrm{Cs}$ and ${ }^{90} \mathrm{Sr}$ comprise most of the total curies in SSTs (Croft 1980). However, it does not make much sense to include these relatively short-lived radionuclides into a long-term hazard ranking that forms the basis for remediation and cleanout levels. A lot of time, money, and occupational dose could be invested in retrieving the short-lived radionuclides and making a large volume of glass. But a disposal system would still be required for the glass, and in a short time (relative to the design life of the engineered barriers) the ${ }^{137} \mathrm{Cs}$ and ${ }^{90} \mathrm{Sr}$ would have decayed away. The ${ }^{137} \mathrm{Cs}$ and ${ }^{90} \mathrm{Sr}$ are already isolated from the environment by the tanks, which are barriers that will out-live the radionuclides if the tank farms are properly closed. The fill material in the tanks, like ordinary Hanford Site soil, would provide a waste matrix that would retard migration. There is little added value in retrieving the radionuclides to make glass so that they can be isolated again in a waste matrix that by itself will greatly outlive the radioactive materials. 


\subsection{INHERENT CHEMICAL HAZARDS}

Appendix B lists the predominant chemicals occurring in SSTs, according to WHC 1985. The list does not include all the chemicals that occur in the tanks, but does include those chemicals that would present the greatest groundwater hazard, based on prevalence of the chemical and strictness of groundwater quality standard (see notes of Appendix B). It is assumed that all chemicals have the potential to eventually reach the groundwater, although nitrate and the halides are the only truly mobile species, and they are dominant with respect to potential human uptake. From Appendix B, the prevalent chemical hazards relative to the groundwater are nitrate, sulfate, fluoride, and chloride.

Appendix $\mathrm{C}$ compares both the airborne control levels and the groundwater quality standards for the appropriate radiological and nonradiological constituents of SSTs. Beryllium is included in this list because it has the most restrictive airborne control limit and it does occur in SSTs (WHC 1995). The bounding concentration appears to be $0.026 \mathrm{~g} / \mathrm{L}$, which would amount to a conservative $98 \mathrm{~kg}$ for $3,800 \mathrm{~m}^{3}$ (1 Mgal) of waste.

Appendixes B and C show that on a mass basis, radioactivity is controlled to a degree that is orders of magnitude more restrictive than nonradioactive materials. For example, the airborne control level for the most prevalent toxic chemical that occurs in SSTs (chromium) is $1.0 \mathrm{E}-7 \mathrm{~g} / \mathrm{cc}$. However, the analogous airborne control limit for ${ }^{239} \mathrm{Pu}$ (a principal risk driver for Hanford Site waste tanks) is $3.2 \mathrm{E}-18 \mathrm{~g} / \mathrm{cc}$, which is nearly eleven orders of magnitude more restrictive. Therefore, chemicals are generally not a concern with respect to the airborne pathway, due to the need to control ${ }^{239} \mathrm{Pu}$. Any disposal system that adequately protects the terrestrial environment from radionuclides would also protect the environment from chemical contaminants, provided that the mass of chemical does not greatly exceed the mass of radionuclides (by a factor greater than the ratio of nonradiological to radiological airborne control levels). This conclusion is consistent with the radiological versus chemical comparisons described by Boothe and others (Boothe et al. 1994).

When groundwater quality standards of radiological and chemical constituents are compared, it is also apparent that radionuclides are controlled much more restrictively. For example, the standard for nitrate is $1.0 \mathrm{E}-2 \mathrm{~g} / \mathrm{L}$, whereas the standard for ${ }^{99} \mathrm{Tc}$ is $2.4 \mathrm{E}-7 \mathrm{~g} / \mathrm{L}$, which is over four orders of magnitude $(41,667)$ more restrictive. The average amount of ${ }^{99} \mathrm{Tc}$ in each SST is estimated to be $6.5 \mathrm{~kg}$ (Colby 1995). The amount of nitrate that would equate to this amount of ${ }^{99} \mathrm{Tc}$, assuming equal mobilities, would be about $2.708 \mathrm{E}+5 \mathrm{~kg}$ per tank, well over a million gallons. Clearly, chemical contamination of the groundwater is generally not a concern, because of the need to control radionuclides. Any disposal system that adequately protects the groundwater from mobile radionuclides would also protect the groundwater from mobile chemical constituents, provided that the mass of chemical does not greatly exceed the mass of radionuclides (by a factor greater than the ratio of nonradiological groundwater standards to radiological groundwater standards, assuming equal mobilities). 
The normalized Track Radioactive Components (TRAC) database (Jungfleisch 1984) gives masses of specific soluble and insoluble chemical species in SSTs, including $\mathrm{Cr}(\mathrm{OH})^{4}$, $\mathrm{Cr}^{+3}, \mathrm{NO}^{2-}, \mathrm{NO}^{3-}, \mathrm{Ag}, \mathrm{Cr}, \mathrm{F}, \mathrm{Mn}, \mathrm{N}$, and $\mathrm{Pb}$. The masses of these chemicals and their respective groundwater quality standards (soluble) or airborne control levels (insoluble) can be used to develop a chemical hazard index for comparing the relative chemical hazards of SSTs. This hazard index is discussed below. It should be remembered, however, that chemicals present a hazard that is many times less than radioactive materials. Generally, the mass of a soluble chemical must at least exceed 208 times the mass of a soluble radionuclide to present a comparable hazard. This factor is based on the ratio of ${ }^{99} \mathrm{Tc}$ to chromium groundwater quality standards. For insoluble radionuclides and chemicals, this factor is generally greater than 100,000 based on the airborne control standards for alpha emitters and beryllium.

\subsection{RELATIVE HAZARDS OF SINGLE-SHIELL TANKS}

Appendix D gives the current liquid and solid volumes in each SST, as well as the inventories of the predominant, long-term radionuclides. The radionuclide inventories are based on normalized TRAC data (Jungfleisch 1984). The inventories are a snapshot in time, based on the liquid and solid volumes as of December 31, 1994 (WHC 1994b). As volumes of waste change in the tanks, and as more representative analytical data are obtained, Appendix D could be updated, as well as subsequent appendixes that depend on it. Appendix $\mathrm{D}$ and subsequent appendixes are adequate for initial planning purposes, and despite any revisions in radionuclide inventories that may be forthcoming, the methodology presented here is sound.

It could be argued that the characterization of tanks according to the normalized TRAC database is not sufficiently refined or accurate enough to do a risk-based evaluation or prioritization. However, the results of this document were repeated using a database comprised of all known sampling data and all TRAC data. The radiological inventory of the tanks was based on the highest indicated value given by either sampling data or TRAC. This, of course, greatly overestimated the tank inventories, yet the results of using this overly conservative database did not significantly alter the results of this document. In other words, the normalized TRAC database is adequate to identify where the hazards of SSTs reside, and it is unlikely that additional analytical data would change the major recommendations of this document.

Appendixes D.1 and D.2 give the prevalent chemical inventories for insoluble and soluble chemicals, respectively. The appendixes also give a chemical hazard index that allows comparison of the chemical hazards of SSTs. The hazard index does not directly allow comparison of chemical hazards with radionuclide hazards, but these hazards can be normalized to the following extent:

The radiological hazard per kilogram of soluble radionuclide is hundreds of times greater than the chemical hazard per kilogram of soluble chemical. The hazard per kilogram 
of insoluble radionuclide is thousands of times greater than the hazard per kilogram for insoluble chemical.

For insoluble chemicals, the hazard index is simply the summation of the ratios of chemical mass in the tank to chemical airborne control level. The airborne control level for a chemical is taken as the Threshold Limit Value (TLV), in accordance with ACGIH 1967. For soluble chemicals, the hazard index is simply the summation of the ratios of chemical mass in the tank to groundwater quality standard. The groundwater quality standard is essentially the federal drinking water standard and is taken from WHC 1993.

Appendix E gives the SST waste volumes, the percent pumpable liquid, a brief tank status (leaker or sound tank), the degree that the tank contains TRU (i.e., $>100 \mathrm{nCi} / \mathrm{g}$ or $0.16 \mathrm{Ci} / \mathrm{m}^{3}$ ), the ${ }^{126} \mathrm{Sn}$ inventory, and two types of ALI totals (mobile and nonmobile) which were computed from Appendix E. It is assumed in Appendix E that ${ }^{239 / 240} \mathrm{Pu},{ }^{241} \mathrm{Am}$, and ${ }^{126} \mathrm{Sn}$ are confined to the solid fraction of the tank waste. This is a conservative assumption because a portion of these radionuclides is soluble or suspended in liquid, and a portion will be removed by saltwell pumping, to be completed by the year 2000 . An additional portion will be readily removed by sluicing. It is also assumed that all the ${ }^{99} \mathrm{Tc},{ }^{129} \mathrm{I},{ }^{79} \mathrm{Se}$, and uranium is soluble and confined to the liquid fraction of the waste. This assumption is also conservative because it means that the threat to the groundwater is over-estimated, although the small threat from uranium in the terrestrial environment is ignored.

Appendix $F$ ranks the tanks in order of nonmobile ALIs contained in the tanks and includes a percent cumulative column. This appendix clearly shows that most of the internal dose hazard is contained in a small number of tanks. For example, 90 percent of the internal hazard is in 41 tanks of 149 , and 99 percent of the internal hazard is contained in 78 tanks.

Appendix F.1 ranks the tanks in order of insoluble chemical hazard index, and Appendix F.2 ranks the tanks in order of soluble chemical hazard index. Nearly 90 percent of the insoluble chemical hazard is contained in only 17 tanks, whereas 90 percent of the soluble chemical hazard is contained in 56 tanks.

Appendix $\mathrm{G}$ ranks the tanks in order of mobile ALIs and includes a percent cumulative. Over 90 percent of the hazard due to mobile radionuclides is contained in 53 tanks. A portion of this hazard will be removed by saltwell pumping; however, most of the hazard will remain because most of the ALIs are tied up in nonpumpable liquid. Sluicing will remove most of the remaining mobile radioactivity.

Appendix $\mathrm{H}$ ranks the tanks by Curies of ${ }^{126} \mathrm{Sn}$, and as with the previous appendixes, most of the hazard is contained in a small number of tanks ( 90 percent in 23 tanks).

Appendixes F, F.1, F.2, G, and H provide the data to be factored into the retrieval and cleanout options to be considered for SSTs. The challenge is to find a combination of nonmobile, mobile, and gamma hazard reduction that is both environmentally acceptable and cost-effective. The insight provided by Appendixes F, F.1, F.2, G, and $\mathrm{H}$ is factored into 
the general criteria of Section 5.1 and into Appendix J, which describes some options for remediation and cleanout levels.

The fact that most of the hazards from SSTs are from nonmobile ALIs and that most of the nonmobile ALIs are contained in a small number of tanks does not imply that only these tanks should be selected for remediation. Other considerations must be factored into the remediation and the cleanout levels, including the following factors:

Leak Status. To get salt cake or sludge out of a tank, water must be introduced for sluicing purposes. This creates a potential for radioactivity and chemicals to leak out of tanks designated as leakers. Although tank integrity is not assumed to last for a long period, it is not good practice to allow the dispersion of wastes into the soil. The wastes should be contained and confined to the smallest possible volume for the longest possible time. If leaking tanks are to be sluiced it is recommended that this process be optimized to retrieve the most waste for the least amount of introduced liquid.

TRU Concentrations. By rule (DOE 1988), TRU normally cannot be disposed of at the Hanford Site (see Section 4.1, which deals with regulatory issues).

Hazardous Waste Concentrations and Masses. Although radioactivity is controlled much more restrictively than chemical hazards, certain chemical mass restrictions apply (see Section 5.1). There are also some chemical anomalies, such as high arsenic concentrations, which are not considered in the predominant list of chemicals or in the chemical hazard indexes.

Watch List for Hydrogen Generation, Organic, and Ferrocyanide. Hydrogen gas generation presents an explosion hazard. Organic constituents in waste increase mobility of such things as TRU, and present gas generation hazards. Ferrocyanide also presents an explosion hazard. It is not clear at this time, whether any of these parameters would dictate retrieval of the waste, rather than some other remediation. For purposes of this report, it will be assumed that none of these parameters by themselves would dictate the retrieval of waste. These watch list conditions may be remedied by filling the tanks with inert material rather than retrieving the waste.

Special Safety or Environmental Concerns. An example would be the high heat load of Tank 241-C-106, which may dictate extensive retrieval of waste to make the disposal system stable.

All of the above considerations are used in the making of Appendix J, Single-Shell Tank Remediation and Hazard Reduction, and the options listed at the end of the appendix. 
WHC-SD-WM-TI-711

Revision 0

\subsection{HAZARDS VERSUS RISKS}

In this document the term hazard is distinguished from the term risk in that risk will include the potential dose through different pathways using various assumptions regarding the migration of radioactive materials into the environment. Whereas there are very large uncertainties in risk calculations and determinations, there are minimal uncertainties in quantifying hazards. This document focuses on the hazards presented by SST waste as determined by the number of ALIs.

\subsection{HAZARDS AS DETERMINED BY ALI}

The value of specifying the number of ALIs in a tank is: with any amount of radioactivity left in SSTs, there are hypothetical cumulative annual public doses (internal person-rem) from the groundwater and terrestrial pathways. These cumulative doses can be calculated in a variety of ways using various modeling assumptions, none of which have high confidence levels over geological periods. Whatever the hypothetical cumulative doses are, they are directly proportional to the number of mobile ALIs and the number of nonmobile ALIs left in the SSTs, for the groundwater and terrestrial pathways respectively. Consequently, to reduce the cumulative internal doses, it is simply necessary to reduce the number of ALIs left in the waste. Specifying hazards in terms of ALIs is also amenable to costs versus risk reduction comparisons.

\subsection{HAZARDS AND RISK ASSESSMENT}

Although the emphasis of this document is on the inherent hazards presented by SSTs, bounding person-rem from existing tank waste is calculated in Section 3.3. This is done to relate these hazards to potential public risk. There have been many risk assessments on Hanford Site SSTs and double-shell tanks, some of which are very current. Examples are listed in Section 7.0, and include: MacFarlane 1994 and 1995, PNL 1995a and 1995b, and Wood 1994. However, none of these actually assess the total public risk, in terms of person/rem or some other risk parameter, due to long-term leakage from a waste tank disposal system. These risk assessments and others done in the past are limited in that doses are calculated as the result of a single intruder into the waste, or perhaps for a single family using a drinking water well located only $100 \mathrm{~m}$ from the disposal system. Such dose calculations are not necessarily indicative of the total long-term risk borne by the public from existing tank waste. Furthermore, these dose calculations do not take probable land-use restrictions into consideration, nor do the references emphasize that such restrictions will be necessary and will be imposed on the 200 Areas for many generations, since there are no plans to remove all defense waste or commercial waste from the 200 Area Plateau. The latter statement has bearing on the decision to exclude short-lived radionuclides from the ALI determination and the external radiation hazard determination. 
It is especially fallacious to base a risk-based strategy for Hanford Site tank disposal on the results of a 100-m drinking water well. Besides the fact that land use restrictions will prohibit such a well, it is also a fact that the groundwater under the 200 Area plateau already contains large plumes of radioactive materials and hazardous chemicals. There are nitrate plumes, a ${ }^{90} \mathrm{Sr}$ plume, a uranium plume, a ${ }^{99} \mathrm{Tc}$ plume, a ${ }^{129} \mathrm{I}$ plume, and other plumes. These plumes will persist for generations and will dissipate very slowly, if at all, when discharges from Hanford Site operating plants cease. Like the Hanford Site plateau itself, the use of the groundwater under the plateau will need to be restricted for generations because it is already, irrevocably contaminated. The contamination that might reach the groundwater from properly disposed of Hanford Site SSTs is probably insignificant compared to the contamination currently in the groundwater and the contamination that may enter the groundwater from other sources.

There are other risk-based tank rankings than those presented here. For example, PNL (1995b) and MacFarlane (1995) both rank SSTs in accordance with risk. However, PNL considers short-term occupational risks as a basis for tank ranking, which cannot be compared with this document. MacFarlane's ranking could be compared with the rankings presented here, except that MacFarlane considers ${ }^{137} \mathrm{Cs}$ and ${ }^{90} \mathrm{Sr}$ in his rankings. This leads to vast differences in the priority of tanks, because MacFarlane is dealing with short-term hazards whereas this document considers only long-term hazards. For example, this document ranks tank TX-118 as sixth according to hazard, but MacFarlane ranks the tank as 146th. This big difference is due to the fact that $241-\mathrm{TX}-118$ has no ${ }^{137} \mathrm{Cs}$ or ${ }^{90} \mathrm{Sr}$ so MacFarlane sees the tank as low hazard, since ${ }^{137} \mathrm{Cs}$ and ${ }^{90} \mathrm{Sr}$ are drivers for the MacFarlane study. However, the tank contains high levels of ${ }^{239} \mathrm{Pu}$, which is why it is ranked sixth in hazard by this document.

\subsection{BOUNDING CUMULATIVE DOSES FROM MOBILE AND NONMOBILE RADIONUCLIDES}

It is exceedingly difficult to precisely estimate the long-term risks from the SST disposal system. No matter what methodology is used to estimate cumulative public dose, there is a high degree of uncertainty in the input assumptions over long periods. In fact, there is simply not a definitive public risk from Hanford Site waste disposal systems. The risk is probabilistic. There is a very high probability that the dose will be zero, and there is a very low probability that the dose would be measurable, for example.

However, it is not necessary to attempt an elaborate dose calculation and probabilistic risk assessment if the bounding cumulative public dose can be shown to be negligible. The bounding cumulative public dose means that person-rem that would not credibly be exceeded. The bounding person-rem would only be exceeded by some incredible catastrophic event, such as a meteor strike on the disposal system or a 100,000-year flood. In the event of such a catastrophe, the dose from failure of the disposal system would very likely be of little comparative consequence. 
WHC-SD-WM-TI-711

Revision 0

The cumulative internal person-rem per year that might be incurred from the current levels of SST waste can easily be bounded by considering the following factors:

- Total, bounding ALIs in SSTs

- Bounding escape fraction (EF) of ALIs per year from the disposal site

- Bounding environmental dispersion factor (DF) of the ALIs that have escaped

- Bounding human uptake fraction (UF) of the dispersed ALIs in the environment.

The bounding person-rem/year is given by:

Person-rem/yr $=$ ALIs $\times$ EF/year $x$ DF x UF x 5 person-rem/ALI.

In Appendix I, it is shown that even using very conservative values for EF, DF, and UF, the bounding internal person-rem/year for the groundwater pathway and the terrestrial pathway from current waste inventories are 0.47 person-rem/year and 0.92 person-rem/year respectively. Bounding external cumulative public dose is about 0.1 person-rem/year. Therefore, the bounding cumulative public dose from SSTs with no waste retrieval appears to be around 1.49 person-rem/year. The majority of the risk ( 70 percent) is due to nonmobile ALIs. It must be emphasized that the annual person-rem estimates presented here should not be taken as real estimates of actual public radiation doses. They are, rather, one of many bounding estimations that could be made, and they are probably as conservative as any that would ever be postulated, including those estimated in the Hanford Defense Waste Environmental Impact Statement (DOE 1987). It should also be pointed out that any residuals proposed for the SSTs are subject to the performance assessment process, where doses to the public and maximum exposed individuals must be rigorously calculated and demonstrated as acceptable, in accordance with regulatory guidance. In the determination of these doses, however, it seems appropriate to assume land restrictions to eliminate intruder scenarios and near-well drinking water pathways, which is currently not being done in performance assessment work.

It could be argued that the dose calculations in Appendix I are not any too conservative because they do not consider accidents. However, if the SSTs are closed properly, with void spaces eliminated, engineered barriers established, and proper land-use restrictions imposed for an appropriate period of time, it is not credible that an accident could occur within the tank farms that would involve the release of a significant amount of radioactivity.

The bounding cumulative annual dose estimated above (conservatively given as 1.49 person-rem/year) compares with a 60,000 person-rem/year background cumulative dose for the 200,000 people currently living around and near the Hanford Site. The bounding 
cumulative public dose from existing SST waste then, is quite trivial when compared to background cumulative public dose. Therefore, it appears that any remediation of the SSTs beyond filling and stabilization can only be justified on the basis of environmental enhancement and public as low as reasonably achievable (ALARA) principles, rather than person-rem and the associated ill-health effects to the general public.

Certainly, all of the tanks should be stabilized and filled with inert material to prevent subsidence, and barriers must be engineered to minimize plant and animal intrusion, and wind or water erosion. Certainly, most of the hazards should be removed from the tanks due to the cumulative hazards that Hanford wastes collectively present. This is only common sense. However, as this document clearly shows, at some point the retrieval of SST waste becomes highly inefficacious (see Appendixes F, G, and H). Appendix J establishes a very conservative preferred option (Option 3), whereby 86 tanks are selected for remediation after saltwell pumping. Implementation of this option will reduce the overall risk from SSTs by at least 99 percent. Retrieval of more tank waste than that given in Option 3 would cost a great deal of money and a very small added reduction in risk would be achieved.

There are, of course, many other approaches that could be used to determine the remediation and the cleanout levels for tanks. Vast amounts of time and money could be consumed in studying and debating this issue. A much more elaborate and sophisticated methodology could be developed and used, rather than the simple, ALI approach used here. For example, elaborate trade-off studies could be made to balance occupational risk versus public risk, and detailed studies could be made to optimize costs versus benefits. However, it does not appear that the results of such costly studies would differ significantly from the common sense approach used in Appendix J. Furthermore, studies to optimize costs of retrieval could certainly be performed, but the cost savings that might be realized from these studies would be small compared to the overall savings achieved from simply implementing the recommendations in Appendix $\mathrm{J}$, and getting on with the main task of cleaning up the Hanford Site.

If additional risk-based studies are to be performed, it is recommended that these studies focus on the relationship of tank waste hazards to the hazards from all the other waste forms and inventories, such as burial grounds, cribs, etc. These studies should adopt the methodology introduced in this document. With such studies, the overall hazard and risk reduction of Hanford remediation programs in general could be assessed. Cost versus benefit evaluations could also be readily made. 
WHC-SD-WM-TI-711

Revision 0

\subsection{REGULATORY ISSUES AND CONSTRAINTS}

There are numerous regulatory issues and constraints regarding retrieval.

\subsection{WASTE ACCEPTANCE CRITERIA FOR SHALLOW LAND BURIAL}

The waste acceptance criteria for shallow land burial of radioactive waste are specified in terms of $\mathrm{Ci} / \mathrm{m}^{3}$ for each radionuclide (Willis 1991). The most restrictive criterion is the standard for TRU (e.g., ${ }^{239} \mathrm{Pu}$ and ${ }^{241} \mathrm{Am}$ ) which is $100 \mathrm{nCi} / \mathrm{g}$ or $0.16 \mathrm{Ci} / \mathrm{m}^{3}$. The $100 \mathrm{nCi} / \mathrm{g}$ is also the regulatory limit for TRU, and federal law prohibits the disposal of TRU at Hanford. If the SSTs do not exceed the regulatory criterion for TRU, it turns out that the waste acceptance criteria are generally not exceeded for all other radionuclides even though the sum of the fractions rule applies.

Appendix E and the column labeled TRU shows that there are 62 tanks that contain regulatory TRU in sludge and salt cake. From a regulatory standpoint, none of this waste could be left in the tanks unless some sort of averaging over the waste matrix is allowed, as with waste drums, or unless special approval is obtained under the provisions of DOE Order $5820.2 \mathrm{~A}$. It is proposed here that averaging over the volume of the SST $\left(3,785 \mathrm{~m}^{3}\right)$ be allowed. This will result in the remediation of no additional tanks above the 86 priority tanks of Option 3.

Another regulatory issue that must be addressed is whether the waste in SSTs is considered high-level waste (HLW) or low-level waste (LLW). Currently the only regulation governing HLW disposal pertains to disposal in a geologic repository. If the NRC classifies residual waste in SSTs (either following retrieval of as much as practical, or existing waste in tanks for which a policy decision is made not to retrieve) as HLW, then regulations would have to be promulgated for disposal of such waste at the Hanford Site. It is proposed here that all SST waste that meets the waste acceptance criteria of WHC-EP-0063 (Willis 1991) be considered LLW. Consequently, by addressing the TRU issue above, the issue of HLW is also addressed and all radioactive waste disposal requirements would be met.

\subsection{HAZARDOUS WASTE DISPOSAL RESTRICTIONS}

Single-shell tank waste consists of both radioactive and hazardous waste components. The radioactive components are regulated under the Atomic Energy Act of 1954 (AEA) and DOE orders and regulations. The hazardous waste components are regulated under the Resource Conservation and Recovery Act of 1976 (RCRA) and the regulations of the U.S. Environmental Protection Agency (EPA) and the State of Washington. The complex regulatory issues regarding the disposal of SST waste presents a definitive conflict of regulatory regimes. That is, RCRA and its regulatory tiers (WAC-303-173) strongly favor removal of the waste in its entirety for disposal, although landfill closure is also allowed. 
On the other hand, the waste is highly radioactive and dangerous to handle, treat, or process. The full spectrum of AEA regulations would dictate that the waste be isolated and handled as little as possible to minimize radiation doses and risks.

Because of the conflict of regulatory regimes, SST waste is regulated as mixed waste under DOE 5400.3 (DOE 1989), to the extent it is not inconsistent with the AEA. Treating highly radioactive waste as if it were normal hazardous waste would definitely be inconsistent with the AEA and radiation regulations. The radiation dose rate from a single 55 -gal drum of typical SST waste would generally be several rem/h, which means that the waste cannot be handled directly. Even the remote handling of SST waste will incur considerable occupational dose, which could only be mitigated at considerable cost. Furthermore, as shown in Section 2.1.2, any disposal system for SSTs that adequately protects the environment from radioactive wastes will also adequately protect the environment from chemical wastes, provided that certain residual mass criteria for chemical wastes are met.

Therefore, it is proposed that the residuals recommended in this document (Option 3) be considered in full compliance with the provisions of DOE Order 5400.3 and the provisions of RCRA and the AEA. Concurrence with this should be sought in negotiations with the Tri-Party Agreement stakeholders, through the approval of closure plans incorporating the preferred cleanout levels. 
WHC-SD-WM-TI-711

Revision 0

\subsection{PROPOSED REMEDIATION AND CLEANOUT STANDARDS}

The general criteria for SST remediation and cleanout are as follows:

- Residual Mobile ALIs. Saltwell pumping should proceed. Consideration should be given to adding water to saltwell pumping in sound tanks in order to retrieve more of the mobile ALIs in the higher priority tanks (see Appendix G). This is because only 20 percent of the mobile ALIs are retrieved through saltwell pumping. Adding additional water to leakers during saltwell pumping is not recommended.

- Residual Nonmobile (Solid) ALIs. Once sluicing operations are set up, it is recommended that at least 99 percent of the solids be retrieved unless it becomes apparent that the process is inefficacious. This criteria holds for leakers as well as sound tanks. It is assumed that allowable leak criteria will be established for sluicing operations.

- Residual ${ }^{126}$ Sn Levels. Retrieval of the ${ }^{126} \mathrm{Sn}$ SST inventory to the point that it is efficacious should be accomplished. The external radiation hazards from ${ }^{126} \mathrm{Sn}$ appear to be much smaller than the hazards due to inhalation of ${ }^{239} \mathrm{Pu}$ and ${ }^{241} \mathrm{Am}$, under the conservative assumptions of this document.

- Acceptable TRU Levels. It is recommended that no regulatory levels of TRU be left in any tank, and that averaging over the volume of the tank be allowed. Regulations mandate that no TRU be disposed of at the Hanford Site.

- Acceptable Mobile Chemical Levels. The mass of a mobile chemical in a tank divided by the mass of radionuclides in the tank should not exceed the ratio of the groundwater standard for that chemical to the groundwater standard for ${ }^{99} \mathrm{Tc}$. The intent here is to ensure that the nonradiological groundwater hazard will never exceed the radiological groundwater hazard. The radionuclide ${ }^{99} \mathrm{Tc}$ is used because it is the predominant radiological constituent for the groundwater pathway. Also, the unity rule applies. That is, the sum of the ratios should not exceed 1.0.

- Acceptable Nonmobile Chemical Levels. The mass of a nonmobile chemical in a tank divided by the mass of radioactivity in the tank should not exceed the ratio of the airborne control standard for the chemical to the airborne control standard for ${ }^{239} \mathrm{Pu}$. This simply ensures that the nonradiological terrestrial hazard will never exceed the radiological terrestrial hazard. The radionuclide ${ }^{239} \mathrm{Pu}$ is used because it is the predominant radiological constituent for internal dose through the terrestrial pathway. Also, the unity rule applies. 
WHC-SD-WM-TI-711

Revision 0

- Other Tank Hazards. A few other hazards should be considered in the remediation and cleanout for each tank. These hazards include the following:

- Any prevalent chemical not considered in the chemical hazard index, or any prevalent long-lived radionuclide not considered in the ALI determination

- Any long-lived gamma emitter that could significantly contribute to the external dose hazard

- Any special safety hazard or special environmental hazard that may be associated with the tank, such as gas generation, explosive potential, high-heat load, etc.

\subsection{OPTIONS FOR TANK REMEDIATION AND CLEANOUT}

Appendix $\mathrm{J}$ is the culminating table for this report. The objective of this appendix is to recommend a preferred option (Option 3) for remediation and cleanout levels, giving due consideration to the general criteria in Section 5.1. With the preferred option, the most cost effective and environmentally sound disposition of SST can be achieved.

Four options are presented at the end of in Appendix J, from selecting only 41 tanks for remediation, to selecting 96 tanks. The reductions in groundwater hazard, inhalation hazard, and external radiation hazard are given for each option. A cost comparison is also made between the options. For purposes of the cost comparison, it was assumed that on the average, the cost of each tank that is selected for remediation is about $\$ 20$ million. This is a rough order of magnitude (ROM) estimate for construction and operating costs relative to retrieval of SST waste. Since the ALI is a measure of hazard and is proportional to risk, the cost of ALIs retrieved is a good measure of the cost of risk mitigation. The lower the cost per ALI retrieved, the more cost effective is the remediation. The retrieval costs in the options described below are expressed in terms of dollars per MALI retrieved.

Option 1. In this option, the 41 tanks containing the highest nonmobile ALIs are selected for remediation. The waste in all other tanks would be left as acceptable residuals. The justification for this option is the fact that most of the hazard and risk and most of the TRU reside in the nonmobile ALIs. About 90 percent of the inhalation hazard, 27 percent of the groundwater hazard and 90 percent of the external radiation hazard is eliminated with this option. It would be appropriate to propose that this option be adopted initially, and then when budget allows, other tanks could be worked off. The cost per million ALI (MALI) retrieved (assuming $\$ 20$ million per tank) is $\$ 111.53$. 


\section{WHC-SD-WM-TI-711}

Revision 0

Option 2. In this option, 71 tanks containing the highest nonmobile ALIs (99 percent) are selected for remediation. The groundwater hazard is reduced by 45 percent and the gamma hazard is reduced by 95 percent. the cost per MALI retrieved goes up to $\$ 180.70$.

Option 3. In addition to the 71 tanks of Option 2, 15 additional tanks are selected for remediation to remove more mobile ALIs. A total of 86 tanks were selected for remediation. This option retrieves 99 percent of the inhalation hazard, 90 percent of the groundwater hazard and 99 percent of the gamma hazard. The majority of hazardous chemicals are also retrieved ( 90 percent of the soluble and 98 percent of the insoluble chemicals). Through saltwell pumping and sluicing, 62 percent of the solids and 90 percent of the liquids currently in SSTs are removed. The cost per MALI retrieved is \$217.59. At this option, adding additional tanks to the retrieval list would reduce the hazard by much less than 0.1 percent, on the average. This is one of the reasons why this option is the preferred option. Other reasons include the following:

1. The overall level of hazard reduction will approach 99 percent. There are two errors that tend to make this level of hazard reduction overly optimistic: (1) It is assumed that 100 percent of the tank waste can be removed by sluicing, which will not always be the case, and (2) Some of the waste has already leaked from the tanks and cannot be retrieved. However, other conservative assumptions more than compensate for these errors. For example, a portion of the ${ }^{239} \mathrm{Pu}$ and other radionuclides are actually soluble (up to 10 percent and more) and saltwell pumping will remove more nonmobile ALIs than assumed in this document. The nonmobile ALIs, specifically ${ }^{239} \mathrm{Pu}$ and ${ }^{241} \mathrm{Am}$, are the principal hazards, comprising 62 percent of the risk.

2. The 99 percent hazard reduction is more in line with the 99 percent retrieval goal of the Tri-Party Agreement.

3. Out of 62 TRU tanks, all but one (241-T-106) is sluiced, and this tank is barely TRU and would not meet the regulatory definition of TRU if averaged over a small volume (about $120 \mathrm{~m}^{3}$ ).

4. Remediation of additional tanks beyond the 86 is not cost effective in that little actual risk is mitigated for the incurred costs. 


\section{WHC-SD-WM-TI-711 \\ Revision 0}

Option 4. In this option, 96 tanks are selected for remediation to achieve an inhalation hazard reduction of 99 percent, a groundwater hazard reduction of 93 percent, a 99 percent reduction in the gamma hazard, and additional reduction in soluble and insoluble chemical hazards. While little is gained in hazard reduction, the cost per MALI retrieved goes up to $\$ 251.99$.

Another option is listed at the end of Appendix $\mathrm{J}$, which is to select all 149 tanks for remediation. Very little additional hazard is mitigated above the preferred option, but the cost per MALI retrieved $(\$ 372.50)$ is more than triple the cost of Option 1.

Of course, many other options and combinations of options could be presented. The watch list tanks could be selected for remediation regardless of the radiological or chemical hazards contained in the tanks, although at this time this does not appear to be justified for those few watch list tanks not selected by the preferred option. More tanks containing mobile ALIs as opposed to nonmobile ALIs could be selected, although the wisdom of this is questionable since the main hazard is from the nonmobile ALIs. In any case, it does not appear to make much sense to sluice more than 80 or 90 SSTs, after saltwell pumping has been completed.

The tanks listed in Table 2 were not selected for sluicing under the preferred option and presently contain no pumpable liquids and acceptable residuals of radiological and chemical wastes:

Table 2. Tanks Not Selected for Sluicing Under Preferred Option.

\begin{tabular}{|c|l|}
\hline Farm & \multicolumn{1}{|c|}{ Tanks } \\
\hline A & $241-\mathrm{A}-105$ \\
\hline B & $241-\mathrm{B}-106,241-\mathrm{B}-108,241-\mathrm{B}-109,241-\mathrm{B}-201,241-\mathrm{B}-204$ \\
\hline BX & $241-\mathrm{BX}-103$ \\
\hline BY & $241-\mathrm{BY}-112$ \\
\hline C & $241-\mathrm{C}-201,241-\mathrm{C}-202,241-\mathrm{C}-203,241-\mathrm{C}-204$ \\
\hline T & $\begin{array}{l}241-\mathrm{T}-101,241-\mathrm{T}-103,241-\mathrm{T}-106,241-\mathrm{T}-108,241-\mathrm{T}-109, \\
241-\mathrm{T}-201,241-\mathrm{T}-202,241-\mathrm{T}-203,241-\mathrm{T}-204\end{array}$ \\
\hline TX & $\begin{array}{l}241-\mathrm{TX}-101,241-\mathrm{TX}-102,241-\mathrm{TX}-103,241-\mathrm{TX}-105,241-\mathrm{TX}-107, \\
241-\mathrm{TX}-110,241-\mathrm{TX}-111,241-\mathrm{TX}-112,241-\mathrm{TX}-113,241-\mathrm{TX}-115, \\
\\
241-\mathrm{TX}-116,241-\mathrm{TX}-117\end{array}$ \\
\hline TY & $241-\mathrm{TY}-102,241-\mathrm{TY}-104,241-\mathrm{TY}-106$ \\
\hline U & $\begin{array}{l}241-\mathrm{U}-101,241-\mathrm{U}-104,241-\mathrm{U}-112,241-\mathrm{U}-201,241-\mathrm{U}-202, \\
241-\mathrm{U}-203,241-\mathrm{U}-204\end{array}$ \\
\hline
\end{tabular}


WHC-SD-WM-TI-711

Revision 0

These 43 tanks are immediately ready for permanent disposal. The recommended methodology is to fill the tanks with inert material to eliminate any void spaces and provide a surface barrier. After saltwell pumping, an additional 20 tanks will contain acceptable residuals and will be available for filling and permanent disposal. 


\section{WHC-SD-WM-TI-711}

Revision 0

This page intentionally left blank. 
WHC-SD-WM-TI-711

Revision 0

\subsection{REFERENCES}

ACGIH, 1967, Threshold Limit Values for 1967, Proceedings of the 29th Annual Meeting of the American Conference of Government Industrial Hygienists, Chicago, Illinois.

Atomic Energy Act of 1954, 42 USC 2011 or 2114 et seq.

Boothe, G. F., Lee, S. R., Petersen, C. A., 1994, Hazard Control Indices for Radiological and Non-radiological Materials, WHC-SD-W306-TI-003, Rev. 0, Westinghouse Hanford Company, Richland, Washington.

Boothe, G. F., 1979, Surface Soil Contamination Standards, RHO-CD-782, Rockwell Hanford Operations, Richland, Washington.

Colby, S. A., 1995, Inventory of ${ }^{99} T c$ from Reprocessing Hanford Spent Fuel, draft, Westinghouse Hanford Company, Richland, Washington.

Croft, A. G., 1980, ORIGEN2-A Revised and Updated Version of the Oak Ridge Isotope Generation and Depletion Code, ORNL 5621, Oak Ridge, Tennessee.

DOE, 1987, Final Environmental Impact Statement - Disposal of Hanford Defense High Level, Transuranic, and Tank Wastes, Hanford Site, Richland Washington, DOE/EIS-0113, U.S. Department of Energy, Washington D.C.

DOE, 1988, Radioactive Waste Management, DOE Order 5820.2A, U.S. Department of Energy, Washington D.C.

DOE, 1989, Hazardous and Radioactive Mixed Waste Program, DOE Order 5400.3, U.S. Department of Energy, Washington D.C.

DOE, 1993, Occupational Radiation Protection; Final Rule, 10 CFR 835, U.S. Department of Energy, Washington D.C.

Ecology, 1991, Dangerous Waste Regulations, WAC 173-303, Washington State Department of Ecology, Olympia, Washington.

Ecology, EPA, and DOE, 1993, Hanford Federal Facility Agreement and Consent Order, as amended, Washington State Department of Ecology, U.S. Environmental Protection Agency, and U.S. Department of Energy, Olympia, Washington.

EPA, 1988, Limiting Values of Radionuclide Intake and Air Concentration and Dose Conversion Factors for Inhalation, Submersion, and Ingestion, EPA-570/1-88-020, Environmental Protection Agency, Washington D. C. 
WHC-SD-WM-TI-711

Revision 0

Jungfleisch, F. M., 1984, Preliminary Estimation of the Waste Inventories in Hanford Tanks through 1980, SD-WM-TI-057, Rockwell Hanford Operations, Richland, Washington.

MacFarlane, D. R., 1994, Consequence Assessment for the High-Level Waste Tanks Probabilistic Risk Assessment, LA-UR-94-3865, Los Alamos National laboratory, Los Alamos New Mexico.

MacFarlane, D. R., 1995, Probabilistic Safety Assessment for Hanford High-Level Waste Tanks, TSA-11-95-062, Los Alamos National Laboratory, Los Alamos, New Mexico.

PNL, 1995a, Integrated Risk Assessment Program: Integrated Risk Assessment Program: Methodology and Results from Qualitative Evaluation of Current Hanford Site Risks to the Public, PNL 10154, Pacific Northwest Laboratories, Richland, Washington.

PNL, 1995b, Hanford Risk-Based Cleanup Strategy, Draft, Pacific Northwest Laboratories, Richland, Washington.

Resource Conservation and Recovery Act of 1976, 42 USC 6901 et seq.

RHO, 1985, Hanford Defense Waste Disposal Alternatives: Engineering Data for the HDW-EIS, RHO-RE-ST-30P, Rockwell Hanford Operations, Richland, Washington.

Rittmann, P. D., 1994, Dose Estimates for the Solid Waste Performance Assessment, WHC-SD-WM-616, Westinghouse Hanford Company, Richland, Washington.

Schmittroth, F. A., 1995, Inventories for Low-Level Waste Tanks, WHC-SD-WM-RPT-164, Westinghouse Hanford Company, Richland, Washington.

WHC, 1993, Environmental Compliance, WHC-CM-7-5, Westinghouse Hanford Company, Richland, Washington.

WHC, 1994a, Federal Facility Agreement and Consent Order Change Control Form, Change Number M-45-93-01, Westinghouse Hanford Company, Richland, Washington.

WHC, 1994b, Waste Tank Summary for Month Ending December 31, 1994, WHC-EP-0182-81, Westinghouse Hanford Company, Richland, Washington.

WHC, 1995, Tank Waste Source Term Inventory Validation, WHC-SD-WM-ER-400, Rev. 0, Westinghouse Hanford Company, Richland, Washington.

Willis, N. P. and G. C. Triner, 1991, Hanford Site Solid Waste Acceptance Criteria, WHC-EP-0063-3, Westinghouse Hanford Company, Richland, Washington. 
WHC-SD-WM-TI-711

Revision 0

Wood, M. I., R. Khaleel, P. D. Rittman, A. H. Lu, S. Finfrock, R. J. Serne, K. J. Cantrell, 1994, Performance Assessment for the Disposal of Low Level Waste in the 200 West Area Burial Grounds, WHC-EP-0645, Westinghouse Hanford Company, Richland, Washington. 
WHC-SD-WM-TI-711

Revision 0

This page intentionally left blank. 


\section{APPENDIX A}

ALIS AND DOSE FACTORS FOR PREDOMINANT TANK WASTE RADIONUCLIDES

\begin{tabular}{|c|c|c|c|}
\hline Radionuclide $^{(1)}$ & $\begin{array}{l}\text { Half-life } \\
\text { (years) }\end{array}$ & $\begin{array}{c}\text { ALI }^{(2)} \\
\text { (curies) }\end{array}$ & $\begin{array}{c}\text { External } \\
\text { dose factor }{ }^{(3)} \\
\left(\mathrm{rem}-\mathrm{km}^{2} / \text { year-Ci) }\right.\end{array}$ \\
\hline${ }^{79} \mathrm{Se}$ & 65,000 & $6 \mathrm{E}-4$ (ingestion) & - \\
\hline${ }^{80} \mathrm{Sr}$ & 29.1 & 4E-6 (inhalation) & \\
\hline${ }^{93} \mathrm{Nb} \mathrm{m}$ & 13.6 & 9E-3 (ingestion) & - \\
\hline${ }^{99} \mathrm{Tc}$ & 213,000 & 4E-3 (ingestion) & - \\
\hline${ }^{126} \mathrm{Sn}$ & 10,000 & - & $5.0 \mathrm{E}-2$ \\
\hline$\overline{129} \mathrm{I}$ & $1.57 \mathrm{E} 7$ & 5E-6 (ingestion) & - \\
\hline${ }^{137} \mathrm{Cs}$ & 30.0 & - & $1.4 \mathrm{E}-2$ \\
\hline$\overline{227} \mathrm{Ac}$ & 21.8 & 2E-7 (inhalation) & - \\
\hline$\overline{{ }^{228} \mathrm{Ra}}$ & 5.75 & - & $2.34 \mathrm{E}-2$ \\
\hline${ }^{233} \mathrm{U}$ & 158,000 & 1E-5 (ingestion) & - \\
\hline${ }^{234} \mathrm{U}$ & 244,000 & 1E-5 (ingestion) & - \\
\hline${ }^{235} \mathrm{U}$ & $7.04 \mathrm{E} 8$ & 1E-5 (ingestion) & - \\
\hline${ }^{238} \mathrm{U}$ & 4.47E9 & 1E-5 (ingestion) & - \\
\hline${ }^{239} \mathrm{Pu}$ & 24,065 & 6E-9 (inhalation) & - \\
\hline${ }^{240} \mathrm{Pu}$ & 6,537 & 6E-9 (inhalation) & \\
\hline$\overline{241} \mathrm{Am}$ & 432.3 & 6E-9(inhalation) & - \\
\hline
\end{tabular}

NOTES

(1) These are the radionuclides in tank waste that would give over 95 percent of the dose through the groundwater pathway or the terrestrial pathway if radioactive materials leaked from the disposal system (Schmittroth 1995). However, on a longterm basis (i.e., > 300 years), the radionuclides with half-lives 30 years or less can be ignored.

(2) If the principal dose pathway for the radionuclide is the groundwater, the ingestion ALI is given; if the principal pathway is the terrestrial pathway, the inhalation ALI is given. If the radionuclide is a gamma emitter the dose factor is given in the next column. The ALIs were taken from EPA 1988.

(3) The dose factors give the annual external radiation caused by a curie of the radionuclide evenly distributed on every $\mathrm{km}^{2}$ of soil surface. The dose factors were taken from Rittmann (1994). 
WHC-SD-WM-TI-711

Revision 0

This page intentionally left blank. 
WHC-SD-WM-TI-711

Revision 0

\section{APPENDIX B}

PREDOMINANT CHEMICALS IN SINGLE-SHELL TANKS

\begin{tabular}{|l|c|c|c|}
\hline \multicolumn{1}{|c|}{ Chemical $^{(1)}$} & $\begin{array}{c}\text { Total grams in } \\
\text { single-shell tanks }^{(2)}\end{array}$ & $\begin{array}{c}\text { Groundwater quality } \\
\text { standard }^{(3)}(\mathrm{g} / \mathrm{l})\end{array}$ & $\begin{array}{c}\text { Ration of } \\
\text { inventory to } \\
\text { Standard }()^{(4)}\end{array}$ \\
\hline Iron+3 & $7.16 \mathrm{E} 8$ & $3.0 \mathrm{E}-1$ & $2.39 \mathrm{E} 9$ \\
\hline Chromium+3 & $2.68 \mathrm{E} 8$ & $5.0 \mathrm{E}-5$ & $5.36 \mathrm{E} 12$ \\
\hline Lead+2 & $2.83 \mathrm{E} 7$ & $5.0 \mathrm{E}-5$ & $5.66 \mathrm{E} 11$ \\
\hline Manganese+3 & $1.21 \mathrm{E} 8$ & $5.0 \mathrm{E}-5$ & $2.4 \mathrm{E} 12$ \\
\hline Nitrate & $1.0 \mathrm{E} 11$ & $1.0 \mathrm{E}-2$ & $1.1 \mathrm{E} 13$ \\
\hline Sulfate & $1.6 \mathrm{E} 9$ & $2.5 \mathrm{E}-1$ & $6.4 \mathrm{E} 9$ \\
\hline Fluoride & $8.12 \mathrm{E} 5$ & $4.0 \mathrm{E}-3$ & $2.0 \mathrm{E} 8$ \\
\hline Chloride & $4.15 \mathrm{E} 8$ & $2.5 \mathrm{E}-1$ & $1.7 \mathrm{E} 9$ \\
\hline
\end{tabular}

\section{NOTES}

(1) This list does not include all chemicals that could be in SSTs. However, it does comprise the predominant and bounding chemicals due to prevalence and strictness of groundwater quality standard. It is assumed that all the chemicals in the table could eventually migrate to the groundwater.

(2) The masses of chemicals were taken from Hanford Defense Waste Disposal Alternatives: Engineering Data for the HDW-EIS, RHO-RE-ST-30P (WHC 1985).

(3) Taken from Environmental Compliance, WHC-CM-7-5 (WHC 1993).

(4) This number represents the degree of predominance of the chemical with respect to groundwater hazard. The predominant chemicals are by far: chromium, lead, manganese, and nitrate. The normalized TRAC data for SSTs gives soluble and insoluble masses for the following chemicals:

$$
\begin{array}{llllll}
\mathrm{Cr}(\mathrm{OH})^{4-} & \mathrm{Cr}^{+3} & \mathrm{Cr} & \mathrm{N} & \mathrm{NO}^{2-} & \mathrm{NO}^{3-} \\
\mathrm{Ag} & \mathrm{F} & \mathrm{Mn} & \mathrm{Pb} & &
\end{array}
$$

The chemical hazard index developed in this document is based on all of the above TRAC chemicals. 
WHC-SD-WM-TI-711

Revision 0

This page intentionally left blank. 
WHC-SD-WM-TI-711

Revision 0

APPENDIX C

GROUNDWATER QUALITY STANDARDS AND AIRBORNE CONTROL LEVELS OF PREDOMINANT RADIONUCLIDES AND CHEMICALS IN SINGLE-SHELL TANKS

\begin{tabular}{|l|c|c|}
\hline \multicolumn{1}{|c|}{$\begin{array}{c}\text { Radionuclide/ } \\
\text { chemical }{ }^{(1)}\end{array}$} & $\begin{array}{c}\text { Airborne control } \\
\text { level }{ }^{(2)} \mathrm{g} / \mathrm{L}\end{array}$ & $\begin{array}{c}\text { Groundwater quality } \\
\text { standard }{ }^{(3)} \mathrm{g} / \mathrm{L}\end{array}$ \\
\hline${ }^{239} \mathrm{Pu}$ & $3.2 \mathrm{E}-15$ & $2.0 \mathrm{E}-11$ \\
\hline${ }^{241} \mathrm{Am}$ & $6.2 \mathrm{E}-17$ & $3.5 \mathrm{E}-13$ \\
\hline${ }^{99} \mathrm{Tc}$ & $1.8 \mathrm{E}-9$ & $2.4 \mathrm{E}-7$ \\
\hline Beryllium & $2.0 \mathrm{E}-9$ & NONE \\
\hline Chromium & $1.0 \mathrm{E}-7$ & $5.0 \mathrm{E}-5$ \\
\hline Nitrate & NONE & $1.0 \mathrm{E}-2$ \\
\hline Lead & $2.0 \mathrm{E}-7$ & $5.0 \mathrm{E}-5$ \\
\hline Manganese & NONE & $5.0 \mathrm{E}-5$ \\
\hline
\end{tabular}

\section{NOTES}

(1) The predominant chemicals were taken from RHO-RE-ST-3OP (WHC 1985).

(2) The radiological airborne control levels were taken from DOE 1993 (10 percent of the Derived Air Concentration Guide) and the nonradiological airborne control levels were taken from ACGIH 1967 (Threshold Limit Values).

(3) The groundwater quality standards are basically the federal drinking water standards. Values were taken from WHC-CM-7-5 (WHC 1993).

This table demonstrates that relative to airborne contamination, the mass of chemicals in tank residuals must greatly exceed the mass of radioactivity $\left({ }^{239} \mathrm{Pu}\right)$ in order to be at the same level of concern. The factor is on the order of $1.0 \mathrm{E}+6$. Therefore, relative to the airborne pathway, chemicals are not of concern due to the presence of radionuclides.

The table also demonstrates that relative to groundwater contamination, the mass of chemicals in tank residuals must greatly exceed the mass of radioactivity to be at the same level of concern. For example, the mass of nitrate must be 41,667 times the mass of ${ }^{99} \mathrm{Tc}$ in order to be of equivalent concern. Nitrate appears to be the bounding chemical relative to migration and groundwater hazard. Although over the course of geological time, such materials as plutonium could eventually enter the groundwater pathway, the rate that they would do so would be extremely slow, so that the concentrations in groundwater and the Columbia river would be extremely low. 
WHC-SD-WM-TI-711

Revision 0

This page intentionally left blank. 
WHC-SD-WM-TI-711

Revision 0

APPENDIX D

CURRENT WASTE VOLUMES AND RADIONUCLIDE INVENTORIES FOR HANFORD SINGLE-SHELL TANKS

D-1 
WHC-SD-WM-TI-711

Revision 0

This page intentionally left blank. 
APPENDIX D

CURRENT WASTE VOLUMES AND RADIONUCLIDE INVENTORIES FOR HANFORD SINGLE-SHELL TANKS

\begin{tabular}{|c|c|c|c|c|c|c|c|c|c|}
\hline TANR & LIQUID (a) & SOLID (b) & \multicolumn{7}{|c|}{ TOTAL CURIES, LIQUD AND SOLID } \\
\hline & $(\mathrm{m} 3)$ & $(\mathrm{m} 3)$ & TG-99 & Sn-126 & $P_{4}-239 / 240$ & $A m-241$ & $1-129$ & Se-79 & Dranium(c) \\
\hline & & & (C) & (C) & (CI) & (Cl) & (Ci) & (Ci) & (C) \\
\hline $\mathbf{S X - 1 0 3}$ & 882.00 & 1590.00 & $1.35 E+03$ & $4.93 E+00$ & $2.09 E+00$ & $1.77 E+03$ & $1.90 E-01$ & $9.95 \mathrm{E}+00$ & $1.20 \mathrm{E}-01$ \\
\hline $5 x-104$ & 761.00 & 1560.00 & $1.89 E+02$ & $5.23 E+00$ & $1.83 E+02$ & $3.60 E+02$ & 1.35E+00 & $6.98 E+01$ & $1.64 \mathrm{E}-02$ \\
\hline $5 x-105$ & 988.00 & 1600.00 & $4.24 E+02$ & $7.37 E-01$ & $1.56 \mathrm{E}+01$ & $6.29 E+02$ & $6.60 \mathrm{E}-12$ & $2.75 E-10$ & $1.47 \mathrm{E}+00$ \\
\hline $5 x-106$ & 965.00 & 1070.00 & $1.60 \mathrm{E}+02$ & $8.88 E+00$ & $8.81 E-04$ & $2.70 \mathrm{E}+02$ & $6.23 E-04$ & $3.23 E-02$ & $1.85 E-01$ \\
\hline $5 x-107$ & 19.00 & 375.00 & $2.05 E-06$ & $1.25 E+01$ & $2.65 E+02$ & $2.96 \mathrm{E}+02$ & $1.17 \mathrm{E}+00$ & $6.10 E+01$ & $5.88 \mathrm{E}-02$ \\
\hline$\overline{s x-108}$ & 19.00 & 310.00 & $4.08 E-06$ & $1.37 E+01$ & $2.85 \mathrm{E}+02$ & $3.19 \mathrm{E}+02$ & $1.64 E-01$ & $8.52 E+00$ & $1.21 \mathrm{E}+00$ \\
\hline $5 x-109$ & 38.00 & 908.00 & 2.05E-06 & $7.27 \mathrm{E}+00$ & $1.72 E+02$ & $1.31 E+02$ & $3.70 \mathrm{E}-01$ & $1.92 \mathrm{E}+01$ & $1.03 E-01$ \\
\hline$\$ X-110$ & 0.00 & 235.00 & $1.27 \mathrm{E}-07$ & $1.63 \mathrm{E}+01$ & $2.75 E+02$ & $4.57 \mathrm{E}+02$ & $1.39 \mathrm{E}-01$ & $7.20 E+00$ & $2.23 \mathrm{E}-01$ \\
\hline $5 x-111$ & 26.00 & 447.00 & $6.08 E-14$ & $1.69 \mathrm{E}+01$ & $3.50 E+02$ & $5.88 E+02$ & $9.81 E-10$ & $8.19 E-08$ & $1.73 E+00$ \\
\hline $\mathrm{s} X-112$ & 11.00 & 337.00 & $4.62 \mathrm{E}-01$ & $8.85 \bar{E}+00$ & $1.98 E+02$ & $1.84 E+02$ & 1.96E-09 & 1.64E-07 & $1.86 \mathrm{E}+00$ \\
\hline $5 x-113$ & 0.00 & 98.00 & $7.64 E+01$ & $2.26 E+00$ & $6.14 \mathrm{E}+01$ & $2.49 E+01$ & 1.96E-09 & 8.19E-08 & $1.14 E+00$ \\
\hline $5 x-114$ & 53.00 & 632.00 & $6.08 E-14$ & $2.17 E+01$ & $4.40 E+02$ & $4.90 \mathrm{E}+02$ & $6.14 E-11$ & $5.12 E-09$ & $1.77 \mathrm{E}+00$ \\
\hline $\mathrm{Sx}-115$ & 0.00 & 45.00 & $1.49 \mathrm{E}+02$ & $5.53 E+00$ & $1.13 E+02$ & $1.01 E+02$ & $5.86 \mathrm{E}-17$ & $2.44 E-15$ & $2.26 E+00$ \\
\hline $\mathrm{T}-101$ & 64.00 & 322.00 & $4.78 E+01$ & $3.75 E-08$ & $7.11 \mathrm{E}-04$ & $5.88 E+01$ & $3.00 E-14$ & $2.50 E-12$ & 2.41E-01 \\
\hline $\mathrm{T}-102$ & 49.00 & 72.00 & $8.105-01$ & $3.12 \mathrm{E}-09$ & 1.88E.05 & $1.00 E+00$ & $0.00 E+00$ & $0.00 E+00$ & $6.41 E-01$ \\
\hline$T-103$ & 15.00 & 87.00 & $4.48 E+00$ & $1.75 \mathrm{E}-03$ & $1.01 E-01$ & $5.62 E+00$ & $3.10 \mathrm{E}-39$ & $2.58 \mathrm{E}-37$ & $2.19 E+00$ \\
\hline$\vec{T} \cdot 104$ & 189.00 & 1490.00 & $2.16 \mathrm{E}+00$ & $3.59 E-01$ & $1.26 E+02$ & $1.33 \mathrm{E}+01$ & $0.00 E+00$ & $0.00 E+00$ & $0.00 E+00$ \\
\hline$T-105$ & 87.00 & 284.00 & $2.04 E-16$ & 1.73E-01 & $1.61 E+02$ & $1.38 E+01$ & $0.00 E+00$ & $0.00 E+00$ & 2.06E-07 \\
\hline $\mathrm{T}-106$ & 7.57 & 71.90 & $1.12 \mathrm{E}-01$ & $1.92 \mathrm{E}-02$ & $1.79 \mathrm{E}+01$ & $1.54 E+00$ & $0.00 E+00$ & $0.00 \mathrm{E}+00$ & $2.06 \mathrm{E}-06$ \\
\hline$T-107$ & 83.00 & 598.00 & 1.05E-16 & $2.94 E-01$ & $3.99 \mathrm{E}+01$ & $1.19 \mathrm{E}+00$ & $0.00 E+00$ & $0.00 E+00$ & $0.00 E+00$ \\
\hline $\mathrm{T}-108$ & 0.00 & 167.00 & 1.99E-01 & $2.94 \mathrm{E}-02$ & $3.99 E+00$ & $1.20 \mathrm{E}-01$ & $3.07 E-11$ & $2.56 E-09$ & $1.385-05$ \\
\hline$\overline{\mathrm{T}}-109$ & 0.00 & 220.00 & $1.24 E+00$ & $3.27 \mathrm{E}-03$ & 4.42E-01 & $1.34 \mathrm{E}-02$ & $5.78 E-03$ & $2.99 \mathrm{E}-01$ & $2.50 \mathrm{E}-05$ \\
\hline$T-110$ & 159.00 & 1280.00 & $6.23 \mathrm{E}-11$ & $4.12 \mathrm{E}-02$ & $1.56 \mathrm{E}+02$ & $4.52 E+00$ & 8.24E-04 & $4.20 E-02$ & $6.35 E-06$ \\
\hline$T-111$ & 189.00 & 1530.00 & $0.00 E+00$ & $3.92 \mathrm{E}-02$ & 1. $13 \mathrm{E}+02$ & $9.39 \mathrm{E}+00$ & $9.81 E-10$ & $4.09 E-08$ & $1.63 \overline{E-04}$ \\
\hline$T \cdot 112$ & 26.00 & 227.00 & $3.22 E-36$ & $5.39 \mathrm{E}-02$ & $1.90 E+02$ & $1.92 E+01$ & $5.32 \mathrm{E}-02$ & 2.75E+00 & $5.10 \mathrm{E}-05$ \\
\hline $\mathrm{TX} \cdot 101$ & 19.00 & 310.00 & $6.38 E-08$ & $6.43 E-09$ & $4.62 E-04$ & $6.29 E-04$ & $1.80 E-01$ & $9.29 \mathrm{E}+00$ & $4.53 E-01$ \\
\hline $\mathrm{TX}-102$ & 83.00 & 738.00 & $6.64 E+00$ & $7.81 \mathrm{E}-10$ & 8.16E-05 & $3.09 E-04$ & $2.66 \mathrm{E}-02$ & $1.37 \mathrm{E}+00$ & $1.89 E_{-01}$ \\
\hline$T X-103$ & 57.00 & 538.00 & $9.54 \mathrm{E}-01$ & $3.12 \mathrm{E}-09$ & $3.96 E-06$ & 6.81E-02 & 1.33E-02 & $6.87 \mathrm{E}-01$ & $3.88 \mathrm{E}-02$ \\
\hline TX-104 & 57.00 & 189.00 & $1.02 E-06$ & $1.20 \mathrm{E}-05$ & $3.57 E-04$ & 4.01E-06 & $4.36 E-03$ & $2.28 E-01$ & $1.06 E+02$ \\
\hline TX-105 & 76.00 & 2230.00 & $6.11 \mathrm{E}+01$ & $1.76 \mathrm{E}-10$ & 5.97E-04 & 2.14E-03 & $1.25 \mathrm{E}-02$ & 6.37E-01 & $3.58 E+00$ \\
\hline$\overline{\mathrm{T}}-106$ & 38.00 & 1680.00 & $6.02 E+00$ & $8.01 E-10$ & 3.94E-06 & 3.91E-05 & $5.95 E-03$ & $3.07 \mathrm{E}-01$ & $1.84 E+01$ \\
\hline $\mathrm{TX}-107$ & 7.57 & 129.00 & $2.91 E-07$ & $4.99 \mathrm{E}-08$ & B.72E-07 & $4.29 \mathrm{E}-07$ & 2.99E-03 & $1.53 E-01$ & $3.17 E+00$ \\
\hline$T \bar{X}-108$ & 0.00 & 507.00 & $2.28 E+01$ & $2.27 E-02$ & $6.06 E-01$ & $6.09 E-01$ & $1.21 \mathrm{E}-03$ & $6.21 \mathrm{E}-02$ & $2.16 E+01$ \\
\hline $\mathrm{TX}-109$ & 38.00 & 1420.00 & $5.81 E+02$ & $4.99 E-01$ & $1.42 \mathrm{E}+02$ & $8.67 E+01$ & $4.75 E-01$ & $2.45 E+01$ & $7.90 E+00$ \\
\hline $\mathrm{TX}-110$ & 57.00 & 1690.00 & $2.08 E+02$ & 4.19E-02 & $1.05 E+01$ & $2.95 E+01$ & $1.14 \mathrm{E}-03$ & $5.66 E-02$ & 2.63E-01 \\
\hline$\overline{\mathrm{T}} \mathrm{X}-111$ & 34.00 & 1370.00 & $3.08 E+01$ & $4.42 E-03$ & $1.11 \mathrm{E}+00$ & $3.02 E+00$ & $1.35 E-01$ & $6.98 E+00$ & $7.09 \mathrm{E}-03$ \\
\hline
\end{tabular}


WHC-SD-WM-TI-711

Revision 0

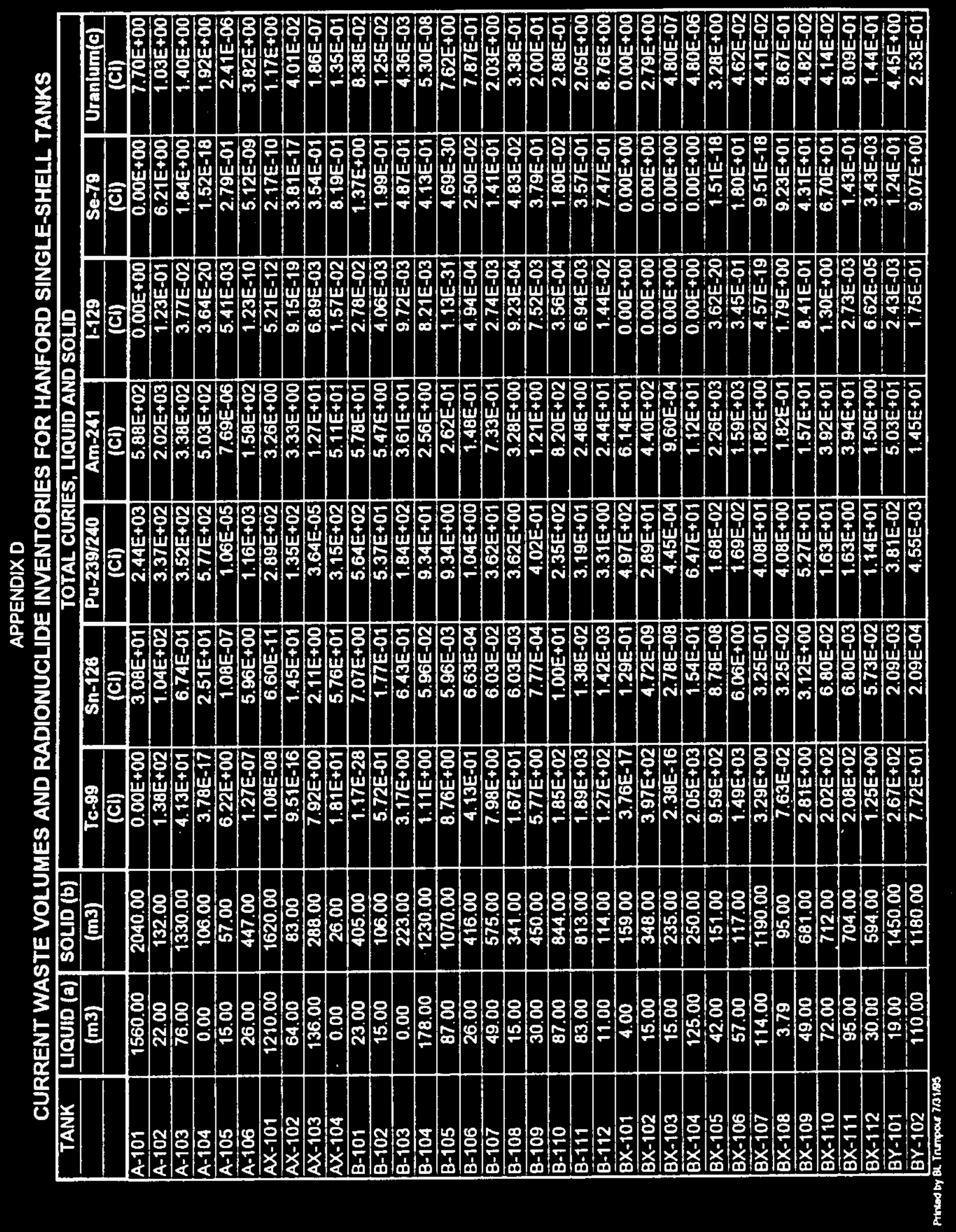

D-4 
APPENDIX D

CURRENT WASTE VOLUMES AND RADIONUCLIDE INVENTORIES FOR HANFORD SINGLE-SHELL TANKS TANK LIQUID (a) SOLID (b) TOTAL CURIES, LQQUID AND SOLID

\begin{tabular}{|c|c|c|c|c|c|c|c|c|c|}
\hline TANK & LIQUID (a) & soLID (b) & & & $-\infty$ & LCOUD AN & LIJ & & \\
\hline & $(\ln 3)$ & (m3) & Te-g9 & Sn-126 & Pu-239/240 & Am-241 & $1-129$ & Se-79 & Uranium(c) \\
\hline & & & (CI) & (C) & (C) & (C) & (C) & (Ci) & (C) \\
\hline BY-103 & 606.00 & 908.00 & $1.25 E+01$ & 5.26E-01 & $9.28 E+02$ & $1.02 E+02$ & $1.80 \mathrm{E}-01$ & $9.29 E+00$ & 1.05E-01 \\
\hline $\mathrm{BY}-104$ & 68.00 & 1470.00 & $2.72 \mathrm{E}+02$ & $6.00 \mathrm{E}+00$ & $1.40 E+02$ & $1.38 E+02$ & 1.10E-03 & $5.55 \mathrm{E}-02$ & $4.07 \mathrm{E}+01$ \\
\hline BY-105 & 727.00 & 1180.00 & $2.12 \mathrm{E}+02$ & $4.32 E+00$ & $8.39 E+01$ & $9.44 \mathrm{E}+01$ & $2.31 E-01$ & 1.19E+01 & $5.48 E-02$ \\
\hline BY-106 & 890.00 & 1450.00 & $2.70 E+02$ & $1.38 E+00$ & $3.14 E+01$ & $7.48 E+01$ & 6.68E-02 & $3.46 E+00$ & $4.45 E-01$ \\
\hline $8 Y-107$ & 95.00 & 912.00 & $9.83 E+01$ & $1.16 E+00$ & $3.11 E+01$ & $3.86 E+01$ & 1.09E-02 & $5.60 E-01$ & $4.92 \mathrm{E}+00$ \\
\hline $\mathrm{BY}-108$ & 34.00 & 839.00 & 1.19E+02 & $1.41 \mathrm{E}+00$ & $3.23 E+01$ & $5.62 \mathrm{E}+01$ & 2.35E-01 & $1.21 E+01$ & $5.02 E+01$ \\
\hline BY-109 & 269.00 & 1330.00 & $8.63 E+01$ & 1.65E-08 & 1.01E-03 & $1.63 E+01$ & 1.84E-01 & $9.51 E+00$ & $1.90 \mathrm{E}+01$ \\
\hline BY-110 & 34.00 & 1470.00 & $2.41 E+02$ & $1.96 E+00$ & $4.85 E+01$ & $7.89 E+01$ & 2.33E-01 & $1.21 E+01$ & $2.54 \mathrm{E}-01$ \\
\hline $\mathrm{BY}-111$ & 0.00 & 1740.00 & $2.73 E+02$ & 1.23E-02 & 2.30E-01 & $5.16 \mathrm{E}+01$ & $8.49 E-02$ & $4.40 E+00$ & $5.30 \mathrm{E}+00$ \\
\hline $\bar{B} \bar{Y}-112$ & 30.00 & 1070.00 & $5.01 E+01$ & $1.05 \mathrm{E}-08$ & 1.24E-03 & $9.44 E+00$ & $1.03 E-01$ & $5.30 \mathrm{E}+00$ & 9.43E-01 \\
\hline C-101 & 11.00 & 320.00 & $2.97 \mathrm{E}+01$ & $1.11 E+00$ & $1.22 E+02$ & $2.98 E+01$ & $7.46 \mathrm{E}-02$ & $3.86 \mathrm{E}+00$ & $3.44 \mathrm{E}-01$ \\
\hline $\mathrm{c}-102$ & 113.00 & 1480.00 & $1.99 E-08$ & $1.11 \mathrm{E}+01$ & $2.06 E+03$ & $6.55 E+02$ & $2.09 \mathrm{E}-01$ & $1.08 E+01$ & $6.72 E-02$ \\
\hline C-103 & 503.00 & 235.00 & $1.60 \mathrm{E}-08$ & $1.74 \mathrm{E}+00$ & $3.04 E+02$ & $8.31 E+01$ & 2.36E-01 & $1.22 E+01$ & $1.18 E+00$ \\
\hline $\mathrm{C}-104$ & 42.00 & 1070.00 & $5.13 E-09$ & $3.17 \mathrm{E}+00$ & $7.11 E+02$ & $5.11 \mathrm{E}+02$ & 4.33E-02 & $2.24 E+00$ & $5.51 E-02$ \\
\hline C-105 & 53.00 & 458.00 & $6.90 \mathrm{E}+02$ & $6.03 E+01$ & $1.52 E+03$ & $6.24 E+03$ & $2.58 E-02$ & $1.335+00$ & $2.07 \mathrm{E}+00$ \\
\hline $\mathrm{C}-106$ & 182.00 & 685.00 & $0.00 E+00$ & $1.06 E+01$ & $3.07 E+02$ & $2.39 E+02$ & $1.92 \mathrm{E}-11$ & $7.97 \mathrm{E}-10$ & $1.59 \mathrm{E}+01$ \\
\hline$\overline{C-1} \overline{7}$ & 95.00 & 945.00 & $1.34 \mathrm{E}+00$ & $2.25 \mathrm{E}+00$ & $2.52 \mathrm{E}+02$ & $7.12 E+01$ & $1.53 \mathrm{E}-11$ & $6.37 \mathrm{E}-10$ & $7.53 \mathrm{E}+00$ \\
\hline C. 108 & 0.00 & 250.00 & 9.14E-04 & $8.71 E-01$ & $8.92 E+01$ & $2.08 \mathrm{E}+01$ & $4.93 E-12$ & $4.11 \mathrm{E}-10$ & $9.71 E+00$ \\
\hline $\mathrm{C}-109$ & 15.00 & 235.00 & 9.21E-01 & $3.45 \mathrm{E}-02$ & $8.66 E-01$ & 8.25E-02 & $6.30 E-01$ & $3.08 E+01$ & $1.48 E+01$ \\
\hline $\mathrm{C}-110$ & 15.00 & 692.00 & $1.74 E-10$ & $1.14 E-01$ & $1.16 E+02$ & $1.28 \mathrm{E}+01$ & $0.00 E+00$ & $0.00 E+00$ & $2.78 \mathrm{E}+00$ \\
\hline $\mathrm{C}-111$ & 0.00 & 216.00 & $7.05 E-01$ & 5.80E-01 & $6.41 \mathrm{E}+01$ & $1.26 E+01$ & 1.17E-03 & $6.04 E-02$ & $3.73 \mathrm{E}+00$ \\
\hline $\mathrm{c}-112$ & 121.00 & 272.00 & $5.82 E-01$ & 6.06E-01 & 6.14E+01 & $1.40 E+01$ & 7.93E-07 & $3.96 \mathrm{E}-05$ & $1.55 \mathrm{E}+00$ \\
\hline $\mathrm{S}-101$ & 363.00 & 1250.00 & $1.24 E+02$ & $4.66 \mathrm{E}+00$ & $1.86 \bar{E}+02$ & $2.49 \mathrm{E}+02$ & $3.37 \mathrm{E}-07$ & $1.78 \mathrm{E}-05$ & $2.42 \mathrm{E}-03$ \\
\hline S-102 & 871.00 & 1210.00 & $1.70 E-07$ & $4.42 \mathrm{E}-01$ & $1.66 \mathrm{E}+01$ & $6.86 \mathrm{E}+00$ & 1.15E-19 & $4.76 E-18$ & $2.37 \mathrm{E}-01$ \\
\hline $\mathrm{S}-103$ & 386.00 & 553.00 & 2.55E-07 & $4.93 \mathrm{E}-02$ & $2.08 \mathrm{E}+00$ & $7.64 \mathrm{E}-01$ & $1.13 \mathrm{E}-12$ & $4.69 \mathrm{E}-11$ & 2.37E-02 \\
\hline S-104 & 110.00 & 1000.00 & $6.39 E+00$ & $4.09 E+00$ & $1.76 \mathrm{E}+02$ & $6.35 \mathrm{E}+01$ & $1.46 E-08$ & $7.69 \mathrm{E}-07$ & $8.94 \mathrm{E}-05$ \\
\hline S-105 & 132.00 & 1590.00 & $1.83 E+01$ & $3.99 \mathrm{E}-01$ & $1.30 \mathrm{E}+01$ & $5.78 \mathrm{E}+00$ & $1.095-01$ & $5.60 E+00$ & $2.39 E+00$ \\
\hline S-106 & 719.00 & 1090.00 & $3.57 \mathrm{E}+01$ & $5.03 \mathrm{E}-02$ & $1.45 \mathrm{E}+00$ & $9.49 E-01$ & $1.63 \mathrm{E}-10$ & $6.81 \mathrm{E}-09$ & $3.51 \mathrm{E}-01$ \\
\hline S-107 & 223.00 & 1200.00 & 2.55E-07 & $6.70 E+00$ & $1.09 E+03$ & $2.39 E+02$ & $2.465-10$ & $1.02 E-08$ & $2.665-02$ \\
\hline S-108 & 481.00 & 1810.00 & $1.04 E+02$ & 7.14E-01 & $2.69 \mathrm{E}+01$ & $9.80 E+01$ & 5.65E-03 & $2.77 \mathrm{E}-01$ & $2.07 E+00$ \\
\hline$\overline{S-109}$ & 534.00 & 1620.00 & $3.60 E+02$ & $2.25 \mathrm{E}+00$ & $2.98 E+00$ & $1.27 \mathrm{E}+02$ & $1.63 \mathrm{E}-02$ & $7.80 E-01$ & $1.36 \mathrm{E}-01$ \\
\hline $\mathrm{S}-110$ & 416.00 & 1060.00 & $2.38 \mathrm{E}+02$ & $2.71 E+00$ & $9.05 E+01$ & $3.82 E+01$ & 3.16E-02 & $1.53 E+00$ & $1.51 \mathrm{E}-02$ \\
\hline S.111 & 776.00 & 1480.00 & $2.22 E+02$ & 4.09E-01 & $9.05 E+00$ & $8.98 \mathrm{E}+00$ & $2.46 \mathrm{E}-10$ & 1.02E-08 & $1.28 E+01$ \\
\hline S-112 & 416.00 & 1560.00 & $1.55 E+03$ & $1.24 E+00$ & $1.01 E+00$ & $6.60 E+02$ & 8.98E-02 & $4.65 E+00$ & 2.47E-01 \\
\hline SX-101 & 552.00 & 1170.00 & $6.87 \mathrm{E}-09$ & $5.66 E+00$ & $1.88 E+02$ & $9.13 E+01$ & 3.13E-01 & $1.60 E+01$ & $2.74 \mathrm{E}-02$ \\
\hline $5 x-102$ & 693.00 & 1360.00 & $7.14 \mathrm{E}-01$ & $5.63 \mathrm{E}-01$ & $1.86 \mathrm{E}+01$ & $1.02 E+01$ & $2.04 E-01$ & $1.06 E+01$ & $8.92 \mathrm{E}-01$ \\
\hline
\end{tabular}


APPENDIX D

CURRENT WASTE VOLUMES AND RADIONUCLIDE INVENTORIES FOR HANFORD SINGLE-SHELL TANKS

\begin{tabular}{|c|c|c|c|c|c|c|c|c|c|}
\hline TANK & LIQUID (a) & SOLID (b) & & & & Livione & SOLID & & \\
\hline & $(\mathrm{m} 3)$ & (m3) & Tc-99 & Sn-126 & Pu-239/240 & Am-241 & $1-129$ & Se-79 & Uranium(c) \\
\hline & & & (C) & (C) & (C) & (Ci) & (C) & (Ci) & (C) \\
\hline $\mathrm{T} x-112$ & 91.00 & 2370.00 & $1.57 E+01$ & 2.25E-04 & $5.78 E-02$ & $1.77 \mathrm{E}-01$ & $3.76 E-01$ & $1.95 E+01$ & $1.93 E+00$ \\
\hline $\mathrm{TX-113}$ & 61.00 & 2240.00 & $5.25 E+00$ & 1.81E-01 & $4.37 E+01$ & $3.79 \mathrm{E}+00$ & $2.45 E-04$ & $1.26 E-02$ & $2.28 E-01$ \\
\hline TX-114 & 57.00 & 1970.00 & $1.47 E+01$ & 1.81E-02 & $4.37 \overline{E+00}$ & $3.79 E-01$ & 5.25E-03 & $2.62 E-01$ & $5.13 E+00$ \\
\hline $\mathrm{TX}-115$ & 72.00 & 2350.00 & $7.01 E+00$ & 2.01E-03 & 4.86E-01 & $4.27 E-02$ & $3.07 E-11$ & $1.285-09$ & $5.70 E-01$ \\
\hline$\overline{T X}-116$ & 87.00 & 2300.00 & $3.53 E+00$ & $8.48 E-13$ & $6.095-07$ & $6.19 E-03$ & 9.97E-03 & 5.13E-01 & $2.51 E+00$ \\
\hline TX-117 & 30.00 & 2340.00 & $1.44 E+00$ & $1.66 E-12$ & $9.68 E-06$ & $1.01 E-02$ & $2.54 E-02$ & $1.29 E+00$ & $1.72 E-05$ \\
\hline$T X-118$ & 103.00 & 1210.00 & $5.46 E+02$ & $4.66 E+01$ & $9.11 E+02$ & $1.04 E+03$ & $3.98 E-06$ & $2.02 E-04$ & 2.92E-05 \\
\hline TY-101 & 0.00 & 447.00 & $1.32 E+00$ & $3.59 E-01$ & $1.76 E+02$ & $2.80 E+01$ & 6.95E-11 & $2.90 E-09$ & 8.21E-08 \\
\hline TY-102 & 53.00 & 189.00 & $1.55 E+02$ & 4.93E-03 & $3.20 E+00$ & $1.405-01$ & $7.28 E-06$ & $3.73 E-04$ & 1.15E-02 \\
\hline TY-103 & 19.00 & 594.00 & $4.32 E+02$ & $1.11 E+00$ & $2.36 E+02$ & $2.26 E+01$ & $3.07 \mathrm{E}-11$ & 1.28E-09 & $8.13 E-06$ \\
\hline$T Y-104$ & 57.00 & 117.00 & $2.84 E-01$ & $1.06 E-01$ & $7.73 E+00$ & $1.40 E+00$ & $5.00 E-02$ & $2.59 E+00$ & 8.23E-06 \\
\hline TY-105 & 0.00 & 874.00 & $6.06 E+00$ & $2.88 E+00$ & $6.12 E+01$ & $1.52 E+01$ & $1.08 E-05$ & $5.46 E-04$ & $9.62 E-01$ \\
\hline $\mathrm{TY}-106$ & 0.00 & 64.00 & $3.19 E-08$ & $3.20 E-01$ & $6.80 E+00$ & $1.69 E+00$ & $3.07 E-03$ & $1.59 \mathrm{E}-01$ & 2.23E-02 \\
\hline$\overline{U-101}$ & 11.00 & 83.00 & $1.16 E+01$ & $2.53 E-01$ & $1.565+00$ & $5.47 E+00$ & $3.95 E-04$ & $2.07 E-02$ & $1.29 E+00$ \\
\hline $\bar{U} \cdot 102$ & 545.00 & 871.00 & $2.92 \mathrm{E}+01$ & $1.65 E-01$ & $6.71 \mathrm{E}-05$ & $3.44 E+00$ & $6.50 \leq-02$ & $3,42 \mathrm{E}+00$ & $4.03 \mathrm{E}-01$ \\
\hline $\mathrm{U}-103$ & 715.00 & 1060.00 & $4.55 \mathrm{E}-03$ & $7.81 \mathrm{E}-10$ & $1.36 \mathrm{E}-04$ & 8.25E-05 & $5.86 E-17$ & $2.44 E-15$ & $2.85 E+00$ \\
\hline $\bar{U}-104$ & 26.00 & 435.00 & $7.22 E-08$ & 1.25E-08 & $1.09 E-07$ & $7.33 E-08$ & $1.28 \mathrm{E}-01$ & $6.65 E+00$ & $7.29 \mathrm{E}-01$ \\
\hline $\mathrm{U}-105$ & 678.00 & 905.00 & $8.41 E-03$ & $6.00 E-03$ & $4.585-02$ & $1.11 \mathrm{E}-01$ & 1.21E.01 & $6.26 E+00$ & $1.47 E-06$ \\
\hline$\overline{\mathrm{U}}-106$ & 314.00 & 541.00 & $3.195-08$ & $2.71 E-08$ & $3.78 E-05$ & 4.81E-07 & $1.34 \mathrm{E}-01$ & $6.92 E+00$ & 1.49E-05 \\
\hline $\mathrm{U}-107$ & 674.00 & 863.00 & $5.75 E+01$ & $3.20 E+00$ & $1.62 \mathrm{E}-04$ & $9.75 E+01$ & 2.42E-01 & $1.25 E+01$ & 1.93E-06 \\
\hline $\mathrm{U}-108$ & 742.00 & 1030.00 & $1.23 \mathrm{E}-02$ & 1.05E-01 & $1.27 E+01$ & $4.97 \mathrm{E}+00$ & $4.15 E-02$ & $2.16 E+00$ & $4.99 \mathrm{E}-02$ \\
\hline $\mathrm{U}-109$ & 689.00 & 1060.00 & $3.56 \mathrm{E}+00$ & $1.19 \mathrm{E}-02$ & $5.75 E-02$ & $1.71 \mathrm{E}-01$ & $7.04 \mathrm{E}-04$ & $3.67 \mathrm{E}-02$ & $5.55 \mathrm{E}-03$ \\
\hline U-110 & 57.00 & 647.00 & $1.99 \mathrm{E}-01$ & $2.87 E+00$ & $2.09 E+02$ & $5.73 \mathrm{E}+01$ & $3.89 E-03$ & $2.03 \mathrm{E}-01$ & $2.00 E-02$ \\
\hline $\mathrm{U}-11 \overline{1}$ & 462.00 & 784.00 & $1.51 E+01$ & $1.06 \mathrm{E}+00$ & $2.29 E+00$ & $2.82 E+01$ & $1.88 E-03$ & $9.45 E-02$ & $9.68 \mathrm{E}-01$ \\
\hline $\mathrm{U}-112$ & 15.00 & 170.00 & $1.97 \mathrm{E}+01$ & $2.26 \mathrm{E}-02$ & 2.55E-01 & $2.92 E-01$ & $1.96 E-19$ & $8.19 \mathrm{E}-18$ & $2.49 E+00$ \\
\hline B-201 & 15.00 & 95.00 & $0.00 E+00$ & $0.00 E+00$ & $0.00 \mathrm{E}+00$ & $0.00 \mathrm{E}+00$ & $5.00 E-03$ & $2.58 \mathrm{E}-01$ & $2.21 E+00$ \\
\hline B-202 & 11.00 & 91.00 & $0.00 E+00$ & $0.00 E+00$ & $1.99 E+02$ & $2.26 E+01$ & $1.67 \mathrm{E}-01$ & $8.24 E+00$ & $7.55 E+00$ \\
\hline $\mathrm{B}-203$ & 23.00 & 170.00 & $0.00 E+00$ & $0.00 E+00$ & $6.49 \mathrm{E}-01$ & $6.71 E-02$ & $1.64 \mathrm{E}+00$ & $8.52 E+01$ & $4.52 \mathrm{E}-01$ \\
\hline$\overline{8-204}$ & 23.00 & 167.00 & $0.00 E+00$ & $0.00 E+00$ & $6.49 \mathrm{E}+00$ & 6.71E-01 & $1.10 \mathrm{E}-01$ & $5.71 E+00$ & 6.09E-01 \\
\hline$\overline{\mathrm{C}}-2 \overline{01}$ & 0.00 & 7.57 & $4.09 \mathrm{E}-04$ & $2.70 \mathrm{E}-03$ & $1.76 E-02$ & 6.86E-03 & $8.06 E-04$ & $4.08 E-02$ & $2.46 E-0$ \\
\hline $\mathrm{C}-202$ & 0.00 & 3.77 & $1.19 \mathrm{E}-16$ & $7.44 \mathrm{E}-03$ & $4.82 \mathrm{E}-02$ & $1.91 \mathrm{E}-02$ & $1.67 \mathrm{E}-13$ & $1.40 E-11$ & 1.33E-01 \\
\hline $\mathrm{C}-203$ & 0.00 & 19.00 & $1.17 \mathrm{E}-09$ & $7.44 \bar{E}-04$ & 4.82E-03 & $1.91 \mathrm{E}-03$ & $6.20 E-04$ & 3.12E-02 & $1.08 E+00$ \\
\hline $\overrightarrow{C-204}$ & 0.00 & 11.00 & $1.77 \mathrm{E}-05$ & $2.82 E-06$ & $1.82 E-05$ & $5.47 E-06$ & $5.04 E-04$ & $2.62 E-02$ & $1.63 \mathrm{E}+00$ \\
\hline$T-201$ & 15.00 & 95.00 & $0.00 E+00$ & $0.00 \mathrm{E}+00$ & $0.00 E+00$ & $0.00 E+00$ & $5.17 \mathrm{E}-03$ & 2.69E-01 & $2.55 E-06$ \\
\hline T.202 & 7.57 & 719.00 & $0.00 E+00$ & $0.00 E+00$ & $2.76 E-01$ & $2.85 \mathrm{E}-02$ & $1.87 E-10$ & $7.80 \mathrm{E}-09$ & $1.72 \mathrm{E}-07$ \\
\hline & 1500 & $11 \overline{7} . \overline{00}$ & $0.00 E+00$ & $0.00 E+00$ & $2.76 E+00$ & $2.85 E-01$ & $1.99 \mathrm{E}-02$ & $1.01 E+00$ & $1.64 \mathrm{E}-01$ \\
\hline
\end{tabular}




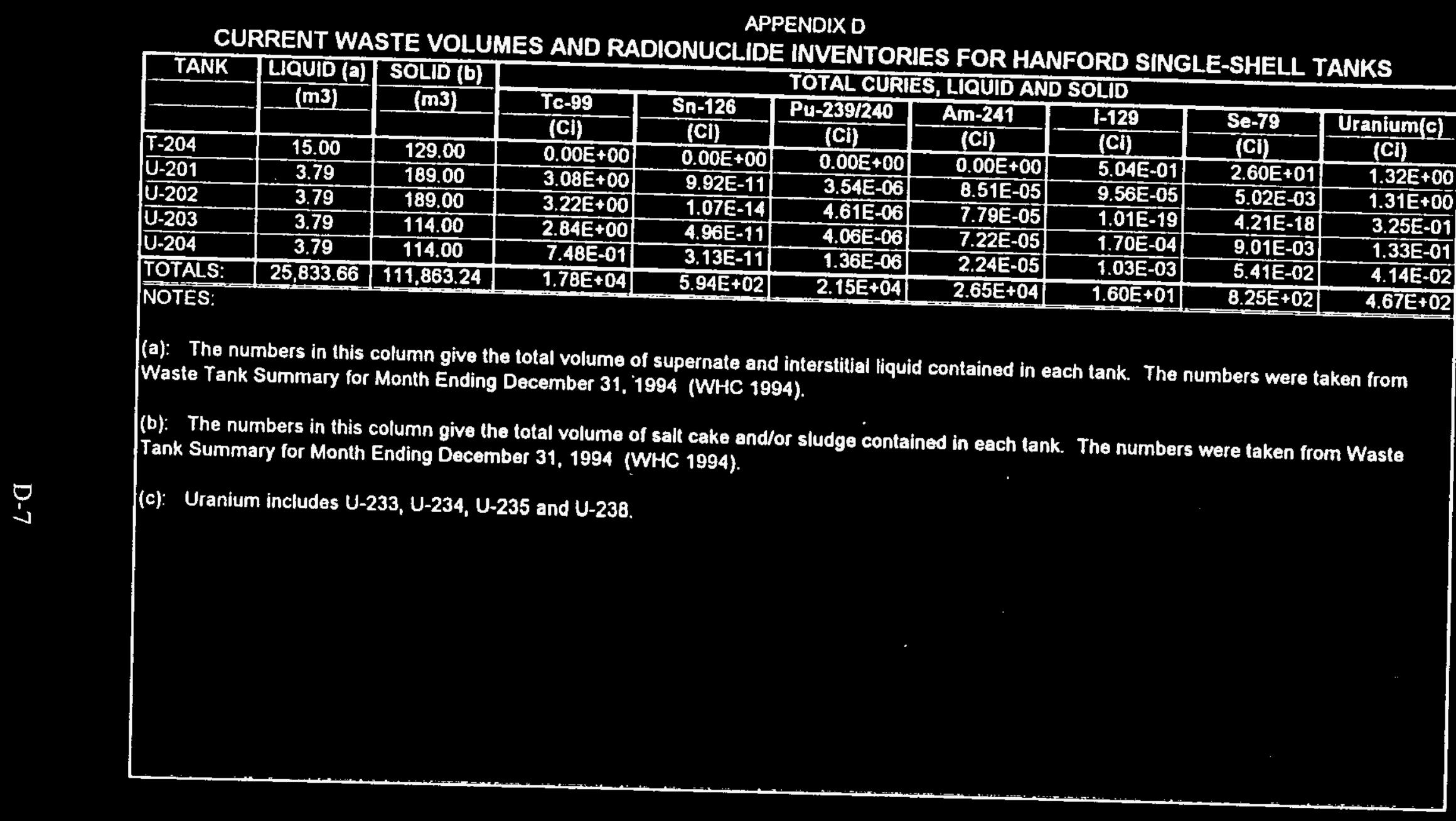


APPENDIX D.1

INSOLUBLE CHEMICAL INVENTORIES AND HAZARD INDEX FOR SINGLE-SHELL TANKS

\begin{tabular}{|c|c|c|c|c|c|c|c|c|c|c|c|c|c|}
\hline TANK & LlaUdD (a) & SOLD (b) & & & & INSOLUEL & E HAZARD & OUS CHEN & ICALS (c) & & & & INSOLUELE \\
\hline A-101 & 1560.00 & 2040.00 & $0.00 E+00$ & $2.23 E+01$ & $8.22 E+02$ & $2.38 E+04$ & $0.00 E+\infty$ & $2.23 E+01$ & $1.52 E+02$ & 2.34E+01 & $5.72 E+03$ & $2.76 E+\infty 0$ & $3.02 E+08$ \\
\hline A-102 & 22.00 & 132.00 & $0.00 E+00$ & $7.66 E-01$ & $1.16 E+02$ & $8.48 E+02$ & $1.74 E-06$ & $7.66 E-01$ & $5.47 E+\infty 0$ & $8.36 E-01$ & $2.30 \mathrm{E}+02$ & $9,91 E-02$ & $1.05 E+07$ \\
\hline A-104 & 0.00 & 106.00 & $0.00 E+\infty$ & $1.14 \mathrm{E}+01$ & $1.51 E-02$ & $8.80 E+01$ & $6.131-25$ & 1.14L+01 & $0.00 E+\infty$ & $0.00 \mathrm{E}+00$ & $2.02 E+01$ & $0.00 E+00$ & $1.14 E+08$ \\
\hline A-105 & 15.00 & 57.00 & $0.00 E+\infty$ & $7.07 E-01$ & $3.12 E-02$ & $5.933+\infty$ & 1.10E-07 & 7.07E-01 & $0.00 E+\infty$ & $0.00 E+00$ & $1.37 E+\infty$ & $0.00 E+\infty$ & $7.07 \mathrm{E}+06$ \\
\hline A-106 & 26.00 & 447.00 & $0.00 E+\infty$ & $1.03 E+01$ & $2.53 E+02$ & $1.94 E+03$ & 1.60E-15 & $1.03 E+01$ & $1.20 E+01$ & $1.84 \mathrm{E}+00$ & $5.22 \mathrm{E}+02$ & 2.17E-01 & $1.09 E+08$ \\
\hline$A x-101$ & 1210.00 & 1620.00 & $0.00 E+\infty$ & $1.59 \mathrm{E}+01$ & $2.37 \mathrm{E}+03$ & $1.90 E+04$ & $7.00 E-17$ & $1.595+01$ & $1.12 E+02$ & $1.77 E+01$ & $5.08 E+03$ & $2.03 E+\infty$ & $2.17 E+08$ \\
\hline Ax-102 & 64.00 & 83.00 & $0.00 E+\infty$ & $1.38 E+\infty 0$ & $8.84 E+01$ & $8.39 E+02$ & $1.23 \mathrm{E}-23$ & $1.38 E+\infty 0$ & $4.22 E+00$ & $7.00 E-01$ & $2.195+02$ & $1.66 E-01$ & $1.65 E+07$ \\
\hline$A \bar{X}-103$ & 136.00 & 283.00 & $0.00 E+\infty 0$ & $2.27 E+00$ & $2.75 E+02$ & $2.71 E+03$ & $8.99 E-08$ & $2.27 E+\infty$ & $1.32 E+01$ & $2.25 E+\infty 0$ & $7.06 E+02$ & $2.35 E-01$ & $2.96 E+07$ \\
\hline$A x-104$ & 0.00 & 26.00 & $0.00 E+\infty$ & 2.61E-01 & $1.15 E-02$ & $2.19 \mathrm{E}+00$ & 2.47E-07 & 2.61E-01 & $0.00 E+00$ & $0.00 E+00$ & $5.07 E-01$ & $0.00 E+\infty 0$ & $2.61 E+06$ \\
\hline $\mathrm{B}-101$ & 23.00 & 405.00 & $0.00 E+\infty$ & $1.78++\infty$ & $2.99 E+01$ & $1.39 \mathrm{E}+03$ & $1.01 E-36$ & $1.78 E+\infty$ & $6.66 E+01$ & $0.00 E+\infty$ & $3.29 E+02$ & $5.51 E-03$ & $4.45 E+07$ \\
\hline B-102 & 15.00 & 106.00 & $0.00 E+\infty 0$ & $1.29 E+00$ & $9.62 E+\infty 0$ & $3.91 E+02$ & $9.58 \mathrm{E}-0 \mathrm{O}$ & $1.29 E+\infty 0$ & $2.13 E+01$ & $0.00 E+\infty 0$ & $9.29 E+01$ & $0.00 E+\infty$ & 2.14E+07 \\
\hline B-103 & 0.00 & 223.00 & $0.00 E+\infty$ & $1.21 E+\infty$ & $2.19 E+01$ & $9.055+02$ & $4.80 \mathrm{E}-08$ & $1.21 E+\infty$ & $4.97 E+01$ & $0.00 E+00$ & $2.15 E+02$ & $0.00 E+00$ & $3.20 E+07$ \\
\hline B-104 & 178.00 & 1230.00 & $0.00 E+\infty$ & $8.52 E+01$ & $5.27 \mathrm{E}+01$ & $1.73 E+03$ & $1.65 \mathrm{E} \cdot 08$ & $8.525+01$ & $5.83 E+02$ & $0.00 E+00$ & $4.14 E+02$ & $0.00 E+\infty$ & $1.09 E+09$ \\
\hline 8-105 & 87.00 & 1070.00 & $0.00 E+\infty 0$ & $1.33 E+01$ & $0.00 \mathrm{E}+\infty$ & $0.00 E+\infty$ & $1.51 E-07$ & $1.33 \mathrm{E}+01$ & $3.15 E+02$ & $0.00 E+\infty$ & $0.00 E+00$ & $0.00 E+\infty 0$ & $2.59 E+08$ \\
\hline B-106 & 26.00 & 416.00 & $0.00 E+\infty 0$ & $1.02 E+00$ & $0.00 E+\infty$ & $7.13 E+02$ & 6.89E-09 & $1.02 E+\infty$ & $1.03 \mathrm{E}+02$ & $0.00 E+\infty$ & $1.64 \mathrm{E}+02$ & $0.00 E+\infty$ & $5.14 E+07$ \\
\hline B-107 & 49.00 & 575.00 & $0.00 E+\infty 0$ & 6.34E+01 & $3.69 E+01$ & $3.60 \mathrm{E}+02$ & $1.42 E-07$ & $6.34 E+01$ & $3.60 E+02$ & $0.00 E+00$ & $9.45 E+01$ & $0.00 E+\infty$ & $778 E+08$ \\
\hline B-108 & 15.00 & 341.00 & $0.00 E+\infty$ & $1.36 E+01$ & $3.15 E+01$ & $1.04 E+03$ & 2.34E-07 & $1.36 E+01$ & $1.28 \mathrm{E}+02$ & $0.00 E+\infty$ & $2.49 E+02$ & $\overline{0.00 E+00}$ & $1.87 \mathrm{E}+08$ \\
\hline B-109 & 30.00 & 450.00 & $0.00 E+\infty$ & $5.40 E+\infty$ & $3.86 E+01$ & $1.395+03$ & $8.28 \mathrm{E}-08$ & $5.40 \mathrm{E}+00$ & $7.46 \mathrm{E}+01$ & $0.00 E+\infty 0$ & $3.31 \mathrm{E}+02$ & $0.00 E+00$ & $8.38 E+07$ \\
\hline B-110 & 87.00 & 844.00 & $0.00 E+\infty 0$ & $8.32 E+01$ & $0.00 E+\infty 0$ & $0.00 E+\infty$ & $2.44 E-06$ & $9.32 E+01$ & $6.49 E+02$ & $0.00 E+\infty 0$ & $0.00 E+\infty$ & $0.00 E+\infty$ & $1.19 E+09$ \\
\hline $0-111$ & 83.00 & 813.00 & $0.00 E+\infty$ & $8.62 E+01$ & $0.00 E+\infty$ & $0.00 E+\infty$ & $3.20 \mathrm{E}-05$ & $8.625+01$ & $5.96 E+02$ & $0.00 E+\infty 0$ & $0.00 E+\infty 0$ & $1.11 E-03$ & $1.105+09$ \\
\hline B-112 & 11.00 & 114.00 & $0.00 E+\infty$ & $6.265+00$ & $0.00 E+\infty 0$ & $0.00 E+\infty$ & $1.76 E-06$ & $6.26 \bar{E}+\infty$ & $3.97 \mathrm{E}+01$ & $0.00 E+\infty$ & $0.00 E+\infty$ & $436 E-02$ & $7.87 E+07$ \\
\hline$B X-101$ & 4.00 & 159.00 & $0.00 E+\infty$ & $6.95 \mathrm{E}+00$ & $2.14 E-01$ & $9.74 E+01$ & $8.49 E-25$ & $6.95 E+\infty 0$ & $0.00 E+00$ & $0.00 E+\infty$ & $2.25 E+01$ & $0.00 E+00$ & 6.95E+07 \\
\hline$B X-102$ & 15.00 & 348.00 & $0.00 E+00$ & $1.02 E+01$ & $2.21 E+\infty$ & $4.15 E+01$ & $5.64 E-06$ & $1.02 E+01$ & $0.00 \mathrm{E}+00$ & $0.00 E+00$ & $1.02 E+01$ & $0.00 E+00$ & $1.02 E+08$ \\
\hline$\overline{B x-103}$ & 1500 & 235.00 & $0.00 E+00$ & $1.58 E+01$ & $3.55 E+\infty$ & $6.51 E+01$ & $3.82 E-24$ & $1.58 E+01$ & $0.00 E+00$ & $0.00 E+\infty$ & $1.60 E+01$ & $0.00 E+00$ & $1.58 E+08$ \\
\hline $8 x-104$ & 125.00 & 250.00 & $0.00 E+00$ & $9.84 E+\infty 0$ & $0.00 E+00$ & $2.99 E+01$ & 3.45E-05 & $9.84 E+00$ & $0.00 E+00$ & $0.00 E+\infty$ & $6.88 E+00$ & $0.00 E+\infty$ & $9.84 E+07$ \\
\hline$B x-105$ & 42.00 & 151.00 & $0.00 E+\infty 0$ & $1.10 E+01$ & $0.00 E+00$ & $3.35 E+01$ & $1.24 E-05$ & $1.10 E+01$ & $0.00 \mathrm{E}+\infty$ & $0.00 E+00$ & $7.71 E+00$ & $0.00 E+00$ & $1.10 E+08$ \\
\hline$B X-106$ & 57.00 & 117.00 & $0.00 E+\infty$ & $7.44 E+\infty 0$ & $0.00 E+\infty$ & $2.27 E+01$ & $4.27 E-05$ & $7.44 E+00$ & $0.00 \mathrm{E}+00$ & $0.00 E+00$ & $5.22 E+00$ & $0.00 E+\infty$ & $7.44 E+07$ \\
\hline $8 X-107$ & 114.00 & 1190.00 & $0.00 E+00$ & $1.33 E+02$ & $8.16 E+01$ & $7.55 E+02$ & $4.923-08$ & $1.33 E+02$ & $7.54 E+02$ & $0.00 E+\infty 0$ & $1.98 \mathrm{E}+02$ & $0.00 E+00$ & $1.63 E+09$ \\
\hline BX-108 & 3.79 & 95.00 & $0.00 E+\infty$ & $1.01 E+01$ & $6.18 \mathrm{E}+\infty 0$ & $5.71 E+01$ & $1.33 E-00$ & $3.01 E+01$ & $5.71 E+01$ & $0.00 E+\infty$ & $1.50 \mathrm{E}+01$ & $0.00 E+\infty$ & $1.24 E+08$ \\
\hline BX-109 & 49.00 & 681.00 & $0.00 E+\infty 0$ & $3.10 E+02$ & $3.79 E+01$ & $8.85 E+03$ & $4.68 E-08$ & $3.10 \mathrm{E}+02$ & $3.51 E+02$ & $0.00 E+\infty$ & $2.05 \mathrm{E}+03$ & $0.00 E+0$ & $3.24 E+09$ \\
\hline$B x-110$ & 7200 & 71200 & $0.00 E+\infty 0$ & $6.23 E+01$ & $138 E+02$ & $2.19 E+03$ & $278 E-06$ & $6.23 E+01$ & $3.47 E+02$ & $0.00 E+00$ & $5.45 \mathrm{E}+02$ & $1.14 E-01$ & $7.62 E+0.3$ \\
\hline $3 x-111$ & 95.00 & 704.00 & $0.00 E+00$ & $2.22 E+01$ & $4.42 E+02$ & $7.99 E+03$ & $2.66 E-06$ & $2.22 E+01$ & $9.50 \mathrm{E}+01$ & $0.00 E+00$ & $1.97 \bar{E}+03$ & $490 \mathrm{E}-01$ & $2.62 \mathrm{E}+0 \mathrm{~B}$ \\
\hline$B X-112$ & 30.00 & 594.00 & $0.00 E+00$ & $5.13 E+01$ & $4.38 E+01$ & $8.04 E+02$ & 2.14E-00 & $5.13 E+01$ & $3.18 E+02$ & $0.00 E+00$ & $1.98 \mathrm{E}+02$ & $0.00 E+\infty$ & $6.40 \mathrm{E}+08$ \\
\hline$\overline{B Y}-101$ & 19.00 & 1450.00 & $0.00 E+\infty$ & $2.79 E+01$ & $8.46 E+02$ & $154 \mathrm{E}+04$ & $3.67 E-06$ & $2.798+01$ & $4.78 E+01$ & $0.00 E+00$ & $3.60 \mathrm{E}+03$ & $9.53 \mathrm{E}-01$ & $3.03 E+08$ \\
\hline $8 \gamma-102$ & 110.00 & 1180.00 & $0.00 E+\infty$ & $2.14 \mathrm{E}+01$ & $5.75 \mathrm{E}+02$ & $1.38 E+04$ & $1.06 E-06$ & $2.14 E+01$ & $4.27 E+01$ & $0.00 E+00$ & $3.35 E+03$ & $8.51 \mathrm{E}-01$ & $2.35 E+08$ \\
\hline BY-103 & 606.00 & 908.00 & $0.00 E+00$ & $2.46 E+01$ & $9.51 E+02$ & $1.73 E+04$ & $1.79 \mathrm{E}-07$ & $2.46 E+01$ & $5.35 E+01$ & $0.00 E+\infty 0$ & $4.26 \mathrm{E}+03$ & $1.07 E+\infty$ & $2.73 E+08$ \\
\hline
\end{tabular}


WHC-SD-WM-TI-711

Revision 0

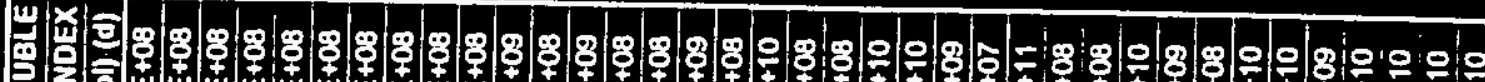

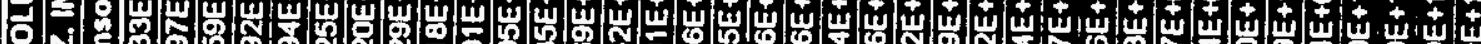
P)

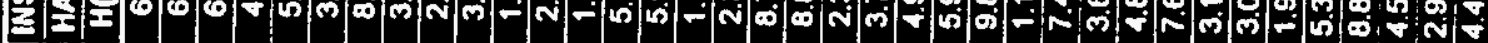

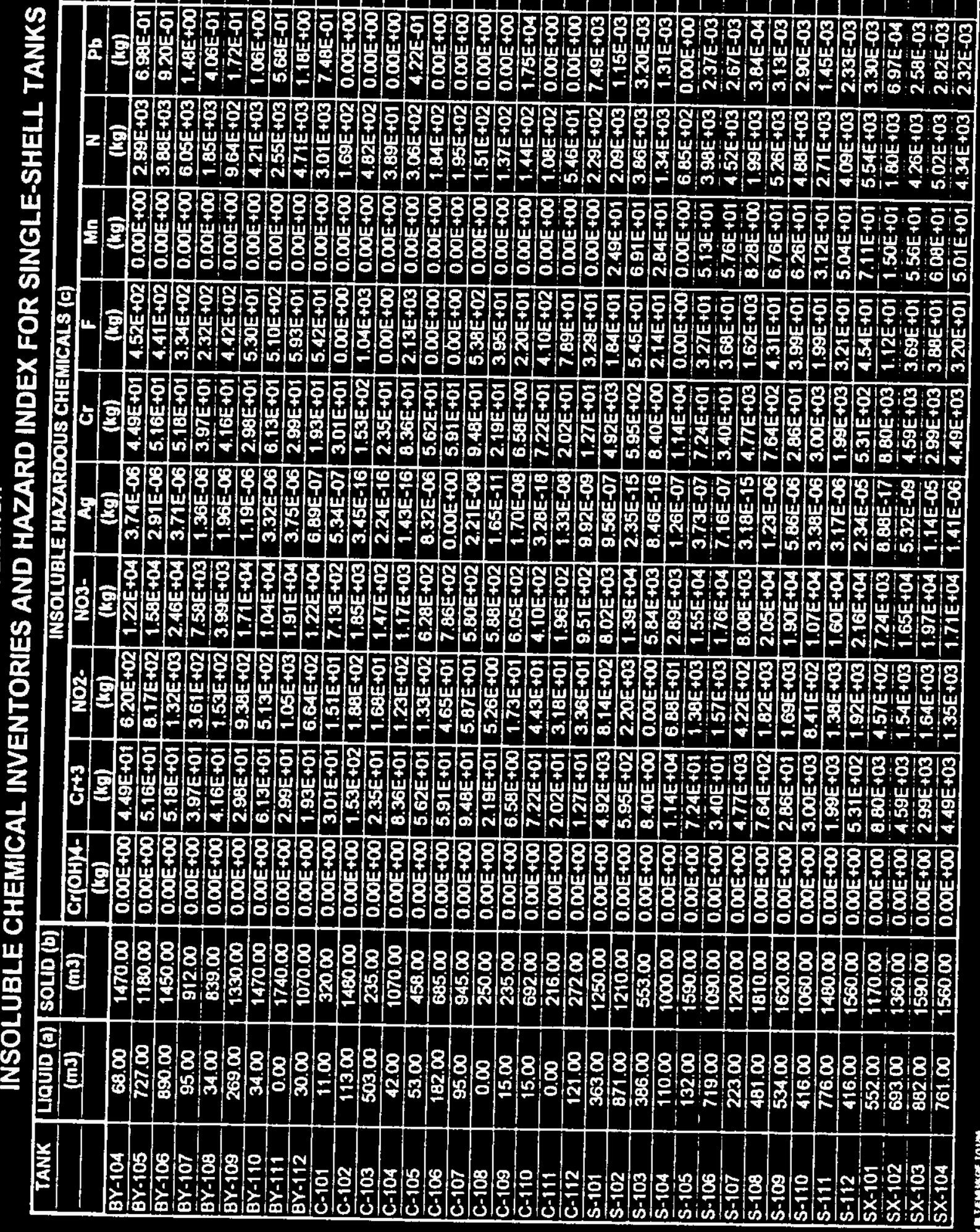


APPENDIX 0.1

INSOLUBLE CHEMICAL INVENTORIES AND HAZARD INDEX FOR SINGLE-SHELL TANKS

\begin{tabular}{|c|c|c|c|c|c|c|c|c|c|c|c|c|c|}
\hline TANK & LIQUD (a) & SOLIO (b) & & & & INSOLUBL & EAZARD & DUS CHEM & TCALS (c) & & & & INSOLUBLE \\
\hline & (m3) & (m) & Cr(OH) & $\mathrm{Cr}+3$ & No2. & $\mathrm{NOS}-$ & A? & $\mathrm{Cr}$ & $F$ & $M n$ & $N$ & $\mathbf{P b}_{\mathbf{b}}$ & HAZ. MOEX \\
\hline & & & $(k 0)$ & (kg) & (kg) & (kg) & (kg) & (kn) & (kI) & (k:) & $(\mathrm{kg})$ & (ke) & $H(\operatorname{lns} a)(d)$ \\
\hline Sx-105 & 988.00 & 1600.00 & $0.00 E+00$ & $3.705+03$ & $1.89 \mathrm{E}+03$ & $2.24 E+04$ & $3.16 E-06$ & $3.70 E+03$ & $4.49 E+01$ & $6.88 E+01$ & $5.72 E+03$ & $3.195-03$ & $3.70 \mathrm{E}+10$ \\
\hline $5 x-106$ & 965.00 & 1070.00 & $0.00 E+00$ & $1.97 E+02$ & $2.07 \mathrm{E}+03$ & $1.095+04$ & $6.61 E-07$ & $1.978+02$ & $5.16 E+01$ & $6.23 E+01$ & $3.13 E+03$ & $2.895-03$ & $2.00 E+09$ \\
\hline$\overline{s x \cdot 107}$ & 19.00 & 375.00 & $0 . \overline{00 E+00}$ & $7.72 E+03$ & $0.00 E+00$ & $1.11 E+03$ & 2.23E-14 & $7.72 E+03$ & $0.00 E+00$ & $0.00 E+00$ & $2.55 E+02$ & $0.00 E+\infty 0$ & $7.72 \mathrm{E}+10$ \\
\hline $5 x-108$ & 19.00 & 310.00 & $0.00 E+00$ & $8.01 E+03$ & $0.00 E+00$ & $1.23 E+03$ & 4.84E-14 & $8.01 E+03$ & $0.00 \mathrm{E}+00$ & $0.00 E+\infty 0$ & $2.83 E+02$ & $0.00 E+00$ & $8.01 E+10$ \\
\hline$s x-109$ & 38.00 & 908.00 & $0.00 E+00$ & 8.59E+03 & $5.685+01$ & $1.845+04$ & $2.72 \mathrm{E}-14$ & $8.59 E+03$ & $0.00 E+00$ & $0.005+00$ & $4.25 E+03$ & $0.00 E+00$ & $8.59 E+10$ \\
\hline $5 x-110$ & 0.00 & 235.00 & $0.00 E+00$ & $7.41 \mathrm{E}+03$ & $1.17 \mathrm{E}+01$ & $3.84 E+03$ & 1.95E-15 & $7.41 \mathrm{E}+03$ & $0.00 E+\infty 0$ & $0.00 E+00$ & $8.87 E+02$ & $0.00 E+00$ & $7.41 E+10$ \\
\hline $5 x-111$ & 26.00 & 447.00 & $0.00 E+00$ & $1.07 E+04$ & $1.60 E+01$ & $5.71 E+03$ & $6.305-22$ & $1.075+04$ & $0.00 E+\infty$ & $0.00 E+00$ & $1.32 \mathrm{E}+03$ & $0.00 E+00$ & $1.07 \mathrm{E}+11$ \\
\hline $5 x-112$ & 11.00 & 337.00 & $0.00 E+00$ & $6.97 E+03$ & $7.43 E+00$ & $3.02 E+03$ & 6.80509 & $6.975+03$ & $0.00 E+00$ & $0.00 E+00$ & $6.97 \overline{E+02}$ & $0.00 \mathrm{E}+00$ & $97 \overline{E+10}$ \\
\hline $5 x-113$ & 0.00 & 88.00 & $0.00 E+00$ & $5.31 E+01$ & $0.00 E+00$ & $2.27 E+01$ & $1.31 \mathrm{E}-06$ & 5.31E+01 & $0.00 E+00$ & $0.00 E+00$ & $5.22 \mathrm{E}+00$ & $0.00 E+00$ & $5.31 E+08$ \\
\hline $5 x-114$ & 53.00 & 632.00 & $0.00 E+00$ & $1.09 E+04$ & $5.20 E+01$ & $1.62 \mathrm{E}+04$ & 6.97E-22 & $1.09 E+04$ & $0.005+00$ & $0.00 \leq+00$ & $3.74 E+03$ & $0.00 E+00$ & $1.00 E+11$ \\
\hline $5 x-115$ & 0.00 & 45.00 & $0.00 E+00$ & 1.15E+03 & $2.35 E+00$ & $7.65 \mathrm{E}+02$ & $2.485-03$ & $1.15 E+03$ & $0.00 E+00$ & $0.00 E+00$ & $1.77 E+02$ & $0.00 E+00$ & $1.15 E+10$ \\
\hline$T-101$ & 64.00 & 322.00 & $0.005+00$ & $1.31 E+01$ & $1.55 E+01$ & $1.44 \bar{E}+02$ & 6.56E-07 & $1.315+01$ & $0.005+\infty 0$ & $0.00 E+00$ & $3.78 E+01$ & $0.00 E+00$ & $31 E+08$ \\
\hline$T-102$ & 49.00 & 72.00 & $0.00 E+00$ & $6.55 E+00$ & $7.505+00$ & $5.605+01$ & 1.11E-00 & $6.55 \overline{E+00}$ & $0.00 E+00$ & $0.00 E+00$ & $1.51 E+01$ & $0.00 E+\infty$ & $6.55 E+07$ \\
\hline$T-103$ & 15.00 & 87.00 & $0.005+00$ & $6.775+00$ & $1.85 E+01$ & $3.41 E+02$ & $6.16 E-08$ & $6.77 \mathrm{E}+00$ & $1.36 E+00$ & $0.00 E+\infty 0$ & $8.40 E+01$ & $0.00 \mathrm{E}+00$ & $32 E+07$ \\
\hline$T-104$ & 189.00 & 1490.00 & $0.00 E+00$ & $1.905+02$ & $1.16 E+02$ & $1.11 \mathrm{E}+03$ & $4.13 E-03$ & $1.90 E+02$ & $8.64 E+02$ & $0.00 \mathrm{E}+00$ & $2.90 E+02$ & $0.00 E+00$ & $2.25 \mathrm{E}+09$ \\
\hline$T-105$ & 87.00 & 284,00 & $0.00 E+00$ & $4.00 E+01$ & $0.00 E+00$ & $0.00 E+00$ & $2.10 \mathrm{E}-24$ & $4.00 \Sigma+01$ & $2.37 E+02$ & $0.00 E+00$ & $0.00 E+\infty 0$ & $0.00 E+00$ & $4.95 E+08$ \\
\hline$T-106$ & 7.57 & 71.90 & $0.00 E+00$ & $8.16 E+00$ & $2.04 E+01$ & $6.565+01$ & $1.84=09$ & $8.16 E+00$ & $1.70 E+01$ & $0.00 E+00$ & $2.12 E+01$ & $0.00 E+00$ & $8.84 E+07$ \\
\hline$T+107$ & 83.00 & 598.00 & $0.00 E+00$ & $5.06 E+01$ & $3.11 E+01$ & $2.87 E+02$ & $1.78 \mathrm{E}-24$ & $5.06 E+01$ & $2.87 E+02$ & $0.00 E+\infty 0$ & $7.53 E+01$ & $0.00 E+00$ & $21 E+08$ \\
\hline$T+108$ & 0.00 & 167.00 & $0.00 E+00$ & $8.285+00$ & 1.37E+01 & $4.21 E+02$ & $2.51 E-09$ & $8.29 E+00$ & 6.68E+01 & $0.00 E+00$ & $1.01 E+02$ & $0.00 E+00$ & $0 E+08$ \\
\hline$T-109$ & 0.00 & 220.00 & $0.005+00$ & 4.985 .01 & $2.22 E+01$ & $9.51 E+02$ & $1.81 E-00$ & $4.985-01$ & $5.28 E+01$ & $0.00 E+00$ & $2.25 E+02$ & $0.005+00$ & $2.61 E+07$ \\
\hline $\mathrm{T}-110$ & 159.00 & 1280.00 & $0.00 E+\infty 0$ & $1.53 E+02$ & $0.00 E+00$ & $0.00 E+00$ & $1.635-18$ & $1.53 E+02$ & $1.11 E+03$ & $5.51 \mathrm{E}+01$ & $0.00 E+00$ & $0.00 E+00$ & $1.99 \mathrm{E}+0 \mathrm{9}$ \\
\hline $\mathrm{T}-111$ & 189.00 & 1530.00 & $0.00 E+00$ & $2.82 \mathrm{E}+02$ & $0.005+00$ & $2.38 E+03$ & $0.00 E+00$ & $2.82 E+02$ & $1.18 E+03$ & $1.98 E+02$ & $5.47 E+02$ & $0.00 E+00$ & $3.33 E+09$ \\
\hline$T-112$ & 26.00 & 227.00 & $0.00 E+\infty$ & $4.55 E+01$ & $0.005+00$ & $2.92 E+02$ & $0.00 E+00$ & $4.55 \mathrm{E}+01$ & $4.60 E+01$ & $0.00 E+00$ & $6.72 E+01$ & $0.00 E+00$ & $4.73 \mathrm{E}+08$ \\
\hline $\mathrm{TX}-\overline{101}$ & 19.00 & 310.00 & $0.00 E+00$ & $1.85 E+03$ & $1.76 E+01$ & $1.29 E+03$ & 4.42E-16 & $1.85 E+03$ & 4.34E-01 & $0.00 E+\infty 0$ & $3.02 E+02$ & $0.00 E+00$ & $1.85 \mathrm{E}+10$ \\
\hline$T X-102$ & 83.00 & 738.00 & $0.00 E+00$ & $9.88<+\infty 0$ & $0.00 E+00$ & $4.04 E+03$ & $1.04 E-07$ & $9.88 E+00$ & $6.02 E+00$ & $0.00 E+\infty 0$ & $9.29 E+02$ & $0.00 E+00$ & $1.01 E+08$ \\
\hline$T X-103$ & 57.00 & 533.00 & $0.00 E+00$ & $1.385+01$ & $0.00 E+00$ & $5.73 E+03$ & $1.595-08$ & $1.38 E+01$ & $8.39 E+00$ & $0.00 E+00$ & $1.32 E+03$ & $0.00 E+00$ & $41 \mathrm{E}+0 \mathrm{~B}$ \\
\hline $\mathrm{TX}-104$ & 57.00 & 189.00 & $0.00 E+00$ & $8.21 E+\infty 0$ & $1.01 E+02$ & $2.63 \mathrm{E}+03$ & $2.02 E-14$ & 8.21E+00 & $2.50 E+00$ & $0.005+00$ & $6.35 E+02$ & $0.00 E+00$ & $8.31 E+07$ \\
\hline Tx-105 & 76.00 & 2230.00 & $0.005+00$ & $5.23 E+01$ & $0.00 E+\infty 0$ & $2.30 E+04$ & $1.02 E-06$ & $5.23 E+01$ & $3.26 E+01$ & $0.00 E+00$ & $5.29 E+03$ & $0.00 E+00$ & $5.365+08$ \\
\hline $\mathrm{TX}-106$ & 38.00 & 1680.00 & $0.00 E+\infty 0$ & $1.18 E+02$ & $0.00 E+00$ & $2.53 E+04$ & $1.07 \mathrm{E}-07$ & $1.18 \mathrm{E}+02$ & 2.43E+01 & $0.00 E+00$ & $5.82 E+03$ & $0.00 \mathrm{E}+00$ & $1.19 E+09$ \\
\hline$T \times-107$ & 7.57 & 129.00 & $0.005+00$ & $3.63 E+00$ & $5.92 \mathrm{E}+01$ & $1.54 E+03$ & $6.28 \mathrm{E}-15$ & $3.63 E+00$ & $1.46 E+\infty 0$ & $0.00 E+00$ & $3.72 E+02$ & $0.00 E+00$ & $3.69 \mathrm{E}+07$ \\
\hline$T X-108$ & 0.00 & 507.00 & $0.00 E+00$ & $1.905+01$ & $2.80 E+02$ & $7.34 \mathrm{E}+03$ & $4.17 \mathrm{E}-07$ & $1.90 E+01$ & $6.95 \mathrm{E}+00$ & $0.00 E+00$ & $1.77 \mathrm{E}+03$ & $0.00 E+00$ & $1.93 E+08$ \\
\hline$T-109$ & 38.00 & 1420.00 & $0.00 E+00$ & $1.49 E+02$ & $9.13 E+01$ & $8.44 E+02$ & $9.15 \overline{0}-0$ & $1.49 \mathrm{E}+02$ & $8.44 E+02$ & $0.00 E+00$ & $2.22 \mathrm{E}+02$ & $0.00 E+00$ & $1.83 \mathrm{E}+09$ \\
\hline $\mathrm{T}-110$ & 57.00 & 1690.00 & $0.005+00$ & $5.295+01$ & $9.42 E+02$ & $2.43 E+04$ & $3.28=00$ & $5.29 E+01$ & $9.03 E+01$ & $0.00 E+00$ & $5.87 E+03$ & $0.00 E+00$ & $5.655+08$ \\
\hline $\bar{T} \overline{x-1} 11$ & 34.00 & 1370.00 & $0.00 E+00$ & $4.81 E+01$ & $7.28 E+02$ & $1.87 \mathrm{E}+04$ & 4.84E-07 & 4.81E+01 & $9.05 E+01$ & $0.00 E+00$ & $4.52 E+03$ & $0.00 E+00$ & $5.17 E+00$ \\
\hline$T x-112$ & 91.00 & 2370.00 & $0.005+\infty 0$ & $5.32 E+01$ & $1.38 E+03$ & $3.60 E+04$ & $2.45 E-07$ & $5.325+01$ & $5.58 E+01$ & $0.00 E+\infty 0$ & 8.69E+03 & $0.00 E+00$ & $5.54 E+08$ \\
\hline$T \mathrm{X}-11 \overline{3}$ & 61.00 & 2240.00 & $0.00 E+00$ & $1.05 E+02$ & $9.71 \mathrm{E}+02$ & $2.45 \mathrm{E}+04$ & $7.93 \mathrm{E}-0 \mathrm{~B}$ & $1.06 E+02$ & $4.24 E+02$ & $0.00 E+00$ & $5.93 \mathrm{E}+03$ & $0.00 E+00$ & $1.23 \mathrm{E}+09$ \\
\hline$T X-114$ & 57.00 & 1970.00 & $0.00 E+00$ & $3.53 E+01$ & $0.00 E+\infty$ & 2. $15 E+04$ & $2.45 \mathrm{E}-07$ & $3.53 E+01$ & $8.70 E+01$ & $0.00 E+00$ & 4.95E +03 & $000 E+00$ & $3.88 \mathrm{E}+08$ \\
\hline
\end{tabular}


APPENDIX 0.1

INSOLUBLE CHEMICAL INVENTORIES AND HAZARD INDEX FOR SINGLE-SHELL TANKS

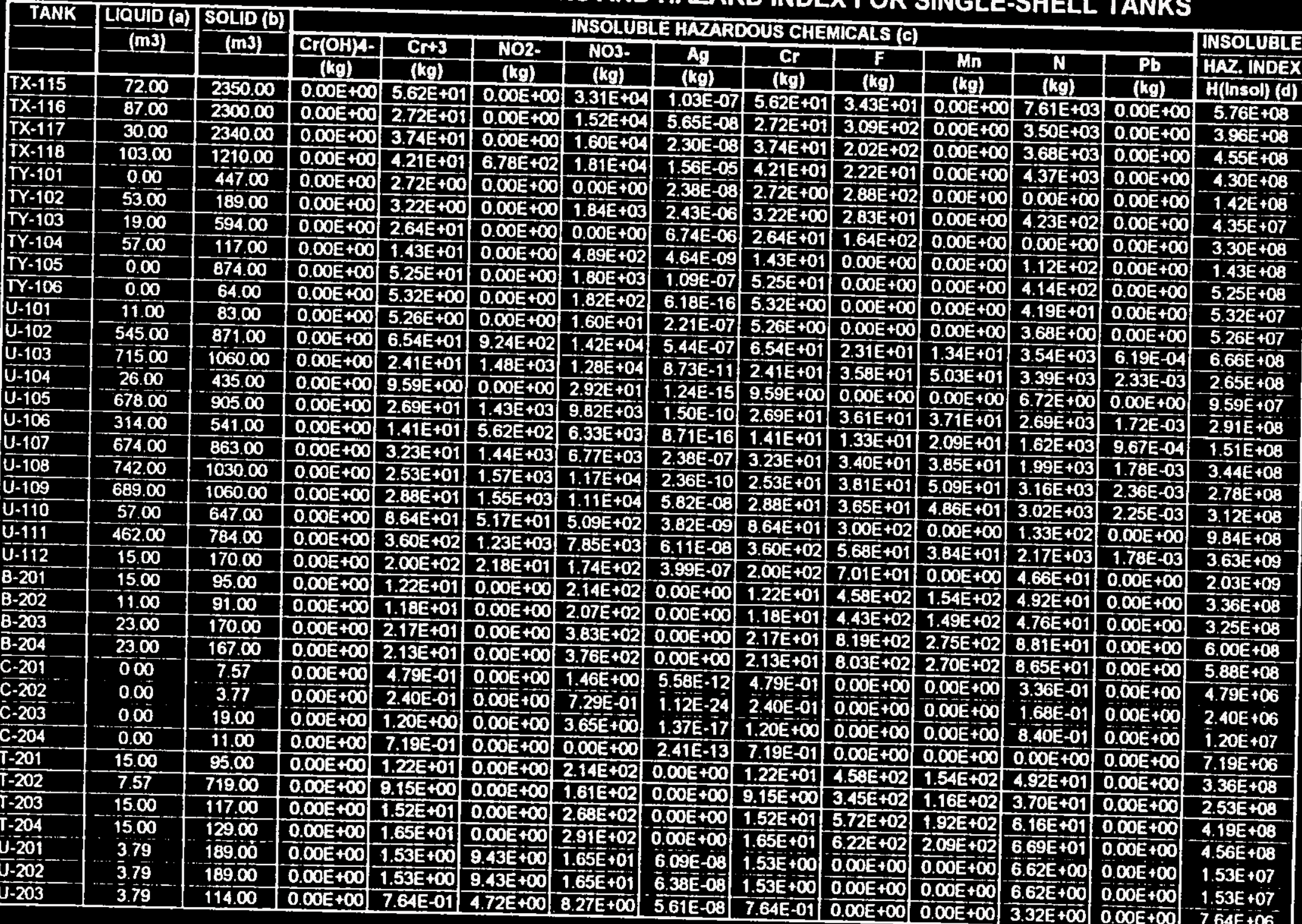




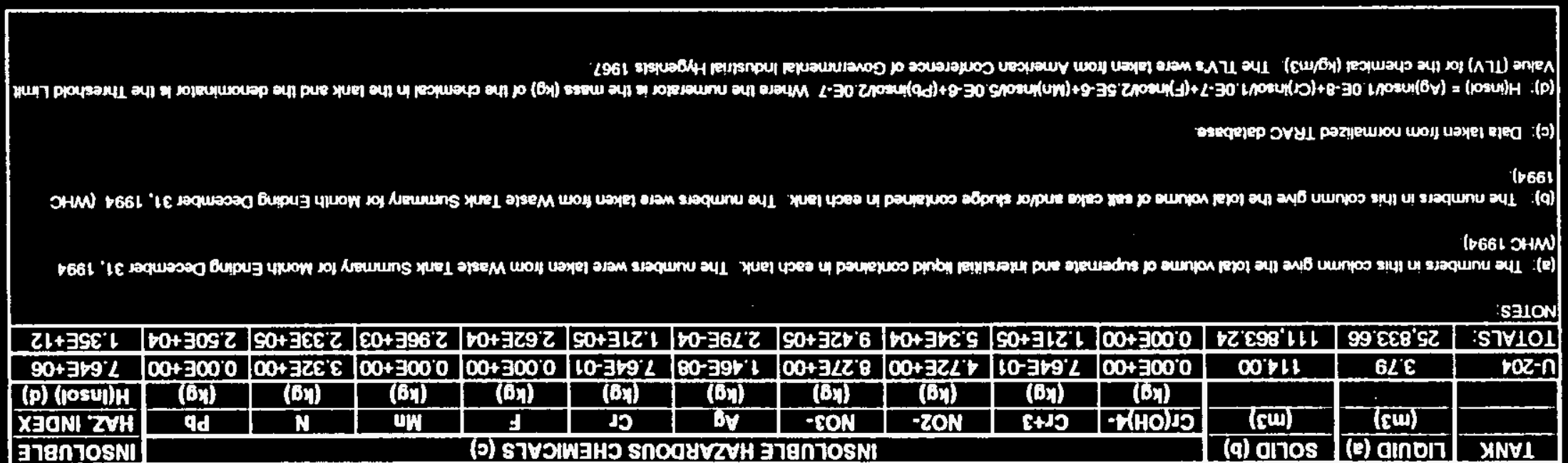

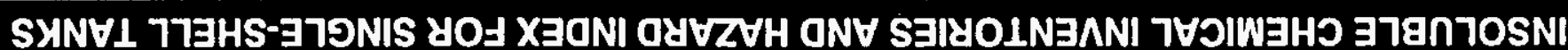

l'OXIONGddV 
APPENDIX D.2

SOLUBLE CHEMICAL INVENTORIES AND HAZARD INDEX FOR SINGLE-SHELL TANKS

\begin{tabular}{|c|c|c|c|c|c|c|c|c|c|c|c|c|c|}
\hline TANK & LLQUD (a) & SOLIO (b) & & & & SOLUBLE & Uhere & JS CHEMIC & ALS (c) & & & & SOLUBLE \\
\hline & $(\mathrm{m} 3)$ & $(\mathrm{m} J)$ & $\mathrm{Cr}(\mathrm{OH}) \mathrm{-}$ & $\mathrm{Cr}+3$ & NO2:- & Nos- & A' & Cr & $F$ & Wn & $\pi$ & $\mathbf{P b}$ & HAZ.WOEX \\
\hline & & & $(\mathrm{kg})$ & $(\mathrm{kg})$ & (28) & $(\mathrm{kg})$ & $(\mathrm{kg})$ & $(\mathrm{kg})$ & (kg) & $(\mathrm{kg})$ & $(\mathrm{kg})$ & $(\mathrm{kg})$ & $H(s o d)(d)$ \\
\hline $\begin{array}{l}A-101 \\
A-102\end{array}$ & 1560.00 & 2040,00 & $4.87 E+03$ & $0.00 E+\infty 0$ & $3.196+05$ & $2.35 \mathrm{E}+06$ & $0.00=+\infty$ & $3.51 E+03$ & $1.51 \mathrm{E}+04$ & $3.36 E+02$ & $6.36 E+05$ & $2.73 E+02$ & $1.50 E+11$ \\
\hline$\frac{A-102}{A-103}$ & $\frac{22.00}{76.00}$ & 132.00 & $1.75 \overline{E+02}$ & $0.00 E+\infty$ & $1.15 E+04$ & $8.40 \mathrm{E}+0.4$ & $0.00 E+\infty 0$ & $1.26 \mathrm{E}+02$ & $5.41 E+02$ & $1.20 \mathrm{E}+01$ & $2.20 \mathrm{E}+0 \mathrm{~A}$ & $9.81 E+00$ & $5.37 E+\infty 9$ \\
\hline A-105 & $\frac{0.00}{15.00}$ & $\frac{106.00}{57.00}$ & $5.78 E+00$ & $0.00 E+\infty$ & $1.50 \mathrm{E}+00$ & $8.71 E+03$ & $0.00 E+00$ & $4.16 E+00$ & $0.00 E+\infty$ & $0.00 E+\infty$ & $2.00 \mathrm{E}+03$ & $0.00 \mathrm{E}+00$ & $2.84 E+08$ \\
\hline$A-106$ & 26.00 & $\begin{array}{r}57.00 \\
47.00\end{array}$ & $3.58 E-01$ & $0.00 E+\infty 0$ & $3.09 E+\infty$ & $5.87 \mathrm{E}+02$ & $0.00 E+\infty$ & $2.58 E-01$ & $0.00 E+\infty$ & $0.00 E+\infty$ & $1.36 E+02$ & $0.00 E+00$ & $1.87 E+07$ \\
\hline$A x-101$ & 1210.00 & $\frac{447.00}{1620.00}$ & $\frac{3.87 E+02}{355 E+03}$ & $0.00 E+\infty$ & $2.51 E+04$ & $1.93 E+05$ & $0.00 E+\infty 0$ & $2.79 E+02$ & $1.1 \mathrm{BE}+03$ & $2.65 E+01$ & $5.19 E+04$ & $2.14 E+01$ & $1.20 \mathrm{E}+10$ \\
\hline$A X-102$ & 64.00 & 83.00 & $\frac{3.55 E+03}{1.30 E+02}$ & $0.00 E+\infty 0$ & $2.34 E+05$ & $1.88 \mathrm{E}+06$ & $0.00 E+\infty$ & $2.56 \mathrm{E}+03$ & $1.11 \mathrm{E}+04$ & $2.55 E+02$ & $5.03 E+05$ & $2.01 E+02$ & $1.13 E+11$ \\
\hline$x-103$ & 136.00 & 288.00 & $4.00 E+02$ & $\frac{0,00 E+\infty}{0,00}=+\infty$ & $8.76 E+03$ & $8.30 E+04$ & $0.00 E+\infty 0$ & $9.36 \mathrm{E}+01$ & $4.18 E+02$ & $1.01 E+01$ & $2.17 E+04$ & $7.48 E+00$ & $4.50 E+09$ \\
\hline$A x-104$ & 0.00 & 26.00 & $1.32 E-01$ & $\frac{0.00 E+\infty}{0.00 E+\infty 0}$ & $2.733+04$ & $2.69 E+05$ & $0.00 E+\infty 0$ & $2.88 E+02$ & $1.31 \mathrm{E}+03$ & $3.23 \mathrm{E}+01$ & $7.01 E+04$ & $2.33 E+01$ & $1.42 E+10$ \\
\hline 8-101 & 23.00 & 405.00 & $1.51 E+02$ & $\frac{0.00 E+\infty}{0.00 E+\infty}$ & $1.14 E+\infty$ & $2.17 E+02$ & $0.00 E+\infty$ & 9.50E-02 & $0.00 E+\infty$ & $0.00 E+\infty 0$ & $5.03 E+01$ & $0.00 E+\infty$ & $6.93 \mathrm{E}+06$ \\
\hline B-102 & 15.00 & $106 . \overline{00}$ & $4.86 E+01$ & $0.00 E+\infty 0$ & 2.96E+03 & $1.38 E+05$ & $0.00 E+\infty 0$ & $1.09 E+02$ & $6.59 E+03$ & $0.00 E+\infty 0$ & $3.26 \mathrm{E}+04$ & $3.52 E-04$ & $7.08 \mathrm{E}+09$ \\
\hline $\mathrm{B}-103$ & 0.00 & 223.00 & $1.12 E+02$ & $0.00 E+\infty$ & $9.72 E+02$ & $3.87 \mathrm{E}+04$ & $0.00 E+\infty$ & $3.50 E+01$ & $2.11 E+03$ & $0.00 E+\infty$ & $9.19 E+03$ & $0.00 E+00$ & $2.15 E+09$ \\
\hline$\overline{B-104}$ & 178.00 & 1230.00 & $1.65 E+02$ & $\frac{0.00 E+00}{0.00 E+\infty}$ & $\frac{2.16 E+03}{5.21 E+03}$ & 8.96E+04 & $0.00 E+\infty$ & $8.06 E+01$ & $4.92 E+03$ & $0.00 E+\infty 0$ & $2.13 E+04$ & $0.00 E+00$ & $4.97 E+09$ \\
\hline$B-105$ & 87.00 & 1070.00 & $5.64 E+02$ & $0.00 E+\infty$ & $\frac{5.21 E+03}{1.12 E+04}$ & $1.72 E+05$ & $0.00 E+\infty 0$ & 1.19E+02 & 1.54E+04 & $0.00 E+\infty 0$ & 4.11E+04 & $0.00 E+00$ & $1.03 E+10$ \\
\hline B-106 & 26.00 & 416.00 & $2.32 E+02$ & $0.00 E+\infty$ & $\frac{1.125+04}{4.48 E+03}$ & $\frac{4.535+05}{1.55+05}$ & $0.00 E+\infty 0$ & $4.06 E+02$ & $258 E+04$ & $0.00 E+\infty$ & $1.06 E+0.5$ & $0.00 E+00$ & $2.53 E+10$ \\
\hline B-107 & 49.00 & 575.00 & $3.21 E+01$ & $0.00=+\infty 0$ & $3.65=+03$ & $\frac{1.65 E+05}{3.565+04}$ & $0.00 E+00$ & $1.67 E+02$ & $1.02 E+04$ & $0.00 \mathrm{E}+\infty$ & $4.39 E+04$ & $0.00 E+00$ & $3 E+10$ \\
\hline B. 108 & 15.00 & $341 . \overline{00}$ & $1.27 \mathrm{E}+02$ & $0,00 E+00$ & $3125+03$ & $3.56 E+04$ & $0.00 E+\infty$ & $231 E+01$ & $6.84 E+03$ & $0.00 E+00$ & $9.34 E+03$ & $0.00 E+\infty 0$ & $E+09$ \\
\hline & 30.00 & 450.00 & $1.71 E+02$ & $0.00 E+00$ & $382 E+03$ & $\frac{1.0 S E+0 S}{1.38 E+05}$ & $0.00 E+\infty 0$ & +01 & $6.68 \mathrm{E}+03$ & $0.00 E+\infty$ & $2.46 E+04$ & $0.00 E+\infty 0$ & $5.96 E+09$ \\
\hline B-110 & 87.00 & 844.00 & $4.73 E+01$ & $0.00 E+\infty 0$ & $3.25 \mathrm{E}-01$ & $\frac{1.38 E+05}{1.27 E+05}$ & $0.00 E+\infty$ & $1.23 E+02$ & $7.38 E+03$ & $0.00 E+00$ & $3.29 E+04$ & $0.00 E+00$ & \\
\hline B-111 & 83.00 & 813.00 & $4.37 E+01$ & $0,00=+00$ & $3.54 E+00$ & $\frac{1.27 \mathrm{E}+05}{1.175+05}$ & $0.00 E+\infty 0$ & $3.41 E+01$ & $1.23 E+04$ & $0.00 E+00$ & $2.92 E+04$ & $0.00 E+00$ & $6.68 E+09$ \\
\hline$\overline{8-112}$ & 11.00 & 114.00 & $2.03 E+02$ & $0,00=+\infty 0$ & $384=+03$ & $\frac{1.17 E+05}{767}$ & $0.00 E+\infty$ & $3.15 E+01$ & $1.13 E+04$ & $0.00 E+00$ & 2.69E+04 & $7.06 \mathrm{E}-05$ & $6.15 \mathrm{E}+09$ \\
\hline$B X-101$ & 4.00 & 159.00 & $3.52 E+\infty 0$ & $0,00 E+\infty$ & $2.128+01$ & & $0.00 E+\infty$ & $1.46 E+02$ & $9.29 E+02$ & $0.00 E+00$ & $1.83 E+04$ & $4.32 E+\infty 0$ & $2 E+03$ \\
\hline BX-102 & 15.00 & 348.00 & 51 & $0 \mathrm{cos}+\mathrm{n}$ & $210+60$ & $9.65 E+03$ & $0.00 E+\infty 0$ & $2.535+\infty 0$ & $0.00 E+\infty 0$ & $0.00 E+\infty$ & $2.23 E+03$ & $0.00 E+\infty 0$ & $2.73 E+08$ \\
\hline $8 x-103$ & 15.00 & 235.00 & $8.03 E+\infty 0$ & $0.00=+\infty$ & $\frac{2.185+02}{3.51 E+02}$ & $4.11 E+03$ & $0.00 E+\infty 0$ & $3.72 E+00$ & $0.00 E+\infty$ & $0.00 E+00$ & $1.01 \mathrm{E}+03$ & $0.00 \mathrm{E}+\infty$ & $1.75 E+08$ \\
\hline BX-104 & 125.00 & 250.00 & $4.99 E+\infty 0$ & $000 E+\infty$ & $000=+0$ & $6.450+03$ & $0.000=+0.0$ & $5.78 E+\infty 0$ & $0.00 E+\infty$ & $0.00 E+\infty 0$ & $1.59 E+03$ & $0.00 E+00$ & $2.75 E+08$ \\
\hline $8 x-105$ & 42.00 & 151.00 & $5.59 E+\infty 0$ & $\overline{0,00 E+\infty}$ & $0.00=+00$ & $2.96 E+03$ & $0.00 E+\infty$ & $3.59 E+00$ & $0.00 E+\infty$ & $0.00 E+00$ & $6.81 \mathrm{E}+02$ & $0,00 E+\infty$ & $1.40 E+08$ \\
\hline $8 x-106$ & 57.00 & 117.00 & $3.77 E+\infty 0$ & $0.00 E+\infty 0$ & $0.00=+\infty$ & $3.32 E+03$ & $0.00 E+\infty$ & $4.02 E+\infty 0$ & $0.00 E+00$ & $0.00 E+\infty 0$ & $7.64 \mathrm{E}+02$ & $0.00 E+\infty 0$ & $1.57 E+08$ \\
\hline $8 X-107$ & 114.00 & 1190.00 & $6.74 E+01$ & $0.00 E+\infty$ & $8.08 E+03$ & $2.24 \mathrm{E}+03$ & $0.00 E+\infty 0$ & $2.71 E+\infty 0$ & $0.00 E+\infty$ & $0.00 \mathrm{E}+00$ & $5.15 E+02$ & $0.00 E+00$ & $1.06 E+08$ \\
\hline $8 x-108$ & 3.79 & 95.00 & $5.10 E+\infty 0$ & $0.00 E+\infty$ & $6.11 E+02$ & $1.47 z+0.4$ & $0.00 E+\infty$ & & $1.43 E+04$ & $0.00 E+00$ & $1.96 \mathrm{E}+04$ & $0.00 E+\infty$ & 6.51E+09 \\
\hline BX-109 & 49.00 & 681.00 & $1.57 E+02$ & $0,00=+\infty$ & $3.75 E+03$ & $5.665+03$ & $0.00 E+00$ & $3.67 \mathrm{E}+00$ & $1.09 E+03$ & $0.00 E+\infty$ & $1.49 E+03$ & $0.00 E+00$ & $4.94 E+08$ \\
\hline BX-110 & 72.00 & 712.00 & $5.54 E+02$ & $0.00 E+00$ & 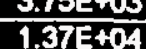 & $8.765+05$ & $0.00 E+\infty 0$ & $1.13 E+02$ & $6.66 \mathrm{E}+03$ & $0.00 E+\infty 0$ & $2.03 E+05$ & $0.00 E+\infty$ & $2.42 E+10$ \\
\hline $8 X-111$ & 95.00 & 704.00 & $2.25 E+03$ & $0.00 E+\infty 0$ & $\frac{1.315+04}{4.385 t h 4}$ & $2.17 E+05$ & $0.00=+\infty$ & $3.995+02$ & $7.05 E+03$ & $0.00 E+\infty$ & $5.40 E+04$ & $1.13 E+01$ & $E+10$ \\
\hline$\overline{B X-112}$ & 30.00 & 594.00 & $9.00 E+01$ & $0,005+\infty 0$ & $4.386+04$ & $7.91 E+05$ & $0.00 E+\infty$ & $1.62 E+03$ & $3.77 \mathrm{E}+03$ & $0.00 E+\infty 0$ & $1.95 \mathrm{E}+05$ & $4.85 E+01$ & $5.38 E+10$ \\
\hline$\overline{B Y}-101$ & 19.00 & 1450.00 & $4.37 E+03$ & $000=+0$ & & $7.965+04$ & $0.00 E+\infty 0$ & $6.48 E+01$ & $8.31 E+03$ & $0.00 E+\infty 0$ & $1.96 \mathrm{E}+0 \mathrm{~A}$ & $0.00 E+\infty 0$ & $5.33 \mathrm{E}+09$ \\
\hline BY-102 & 110.00 & 1180.00 & $3.90 E+03$ & $0.00 E+\infty 0$ & $8.3815+04$ & $1.53 E+16$ & $0.00 E+\infty$ & $3.15 E+03$ & $4.74 E+03$ & $0.00 E+00$ & $3.77 E+05$ & $9.43 \mathrm{BE}+01$ & $1.04 E+11$ \\
\hline 8Y-103 & 06.00 & 908.00 & $4.89 E+03$ & $0.00 E+00$ & $9.42 E+04$ & $\frac{1.36 \mathrm{E}+06}{17 \mathrm{E}}$ & $\frac{0.00 E+00}{10}$ & $2.81 E+03$ & $4.23 E+03$ & $0.00 E+00$ & $3.35 E+05$ & $8.42 E+01$ & $9.24 \mathrm{E}+10$ \\
\hline & & & & & 0 & 1./11E+U0 & $0.00=+00$ & $3.52 E+03$ & $5.30 E+03$ & $0.00 \mathrm{E}+\infty 0$ & $4.22 E+05$ & $1.06 E+02$ & $1.16 E+11$ \\
\hline
\end{tabular}


APPENDIX D.2

SOLUBLE CHEMICAL INVENTORIES AND HAZARD INDEX FOR SINGLE-SHELL TANKS




WHC-SD-WM-TI-711

Revision 0

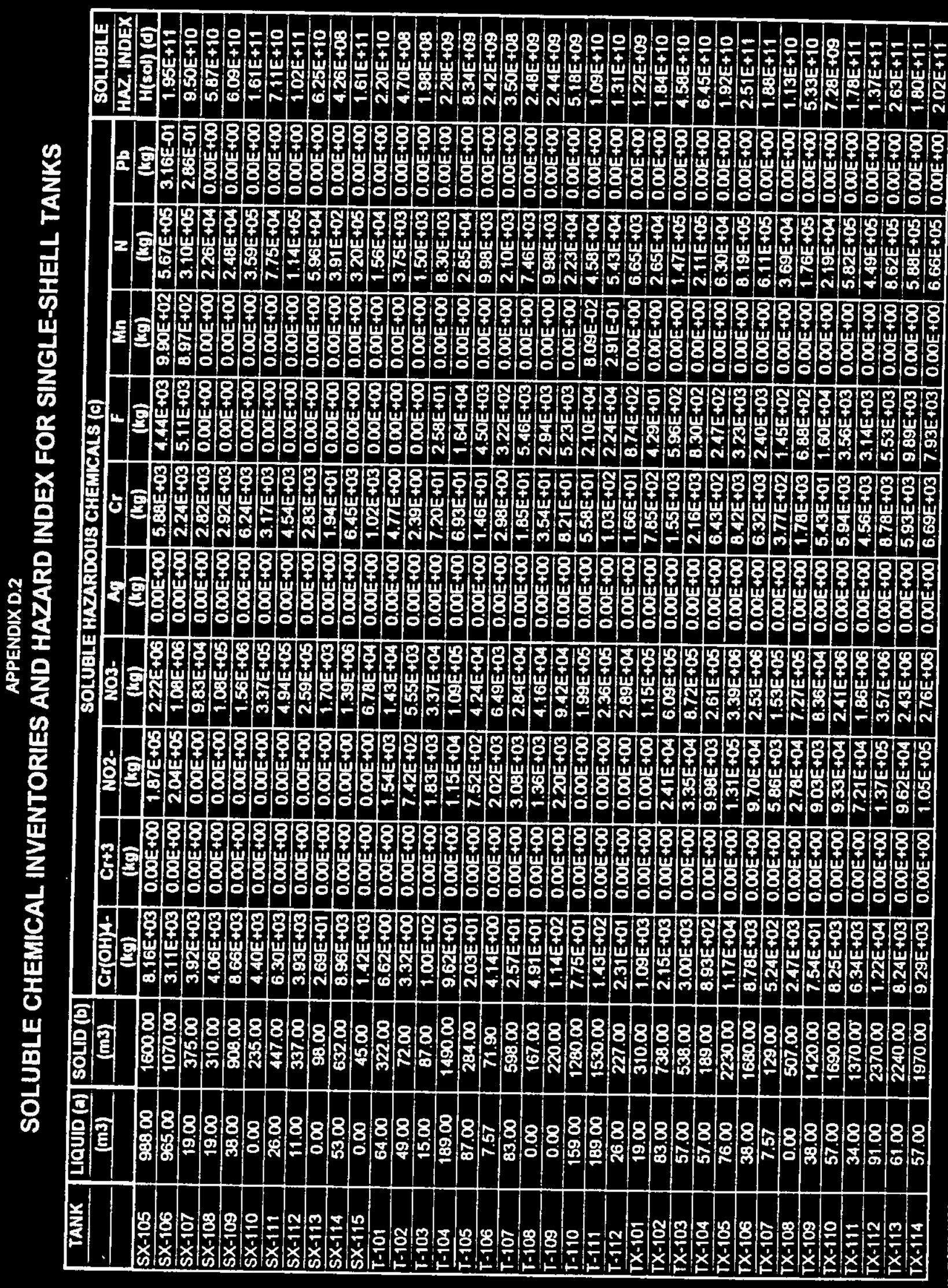

D-15 


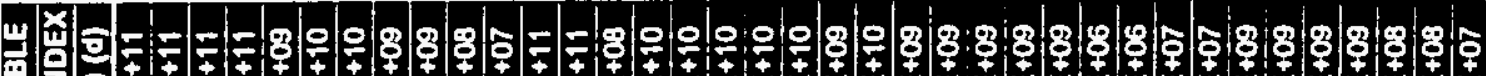

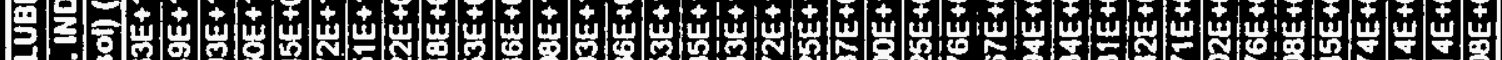
万人

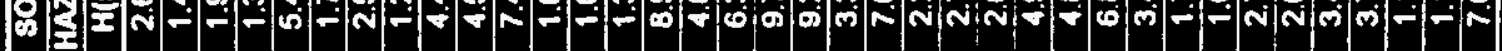

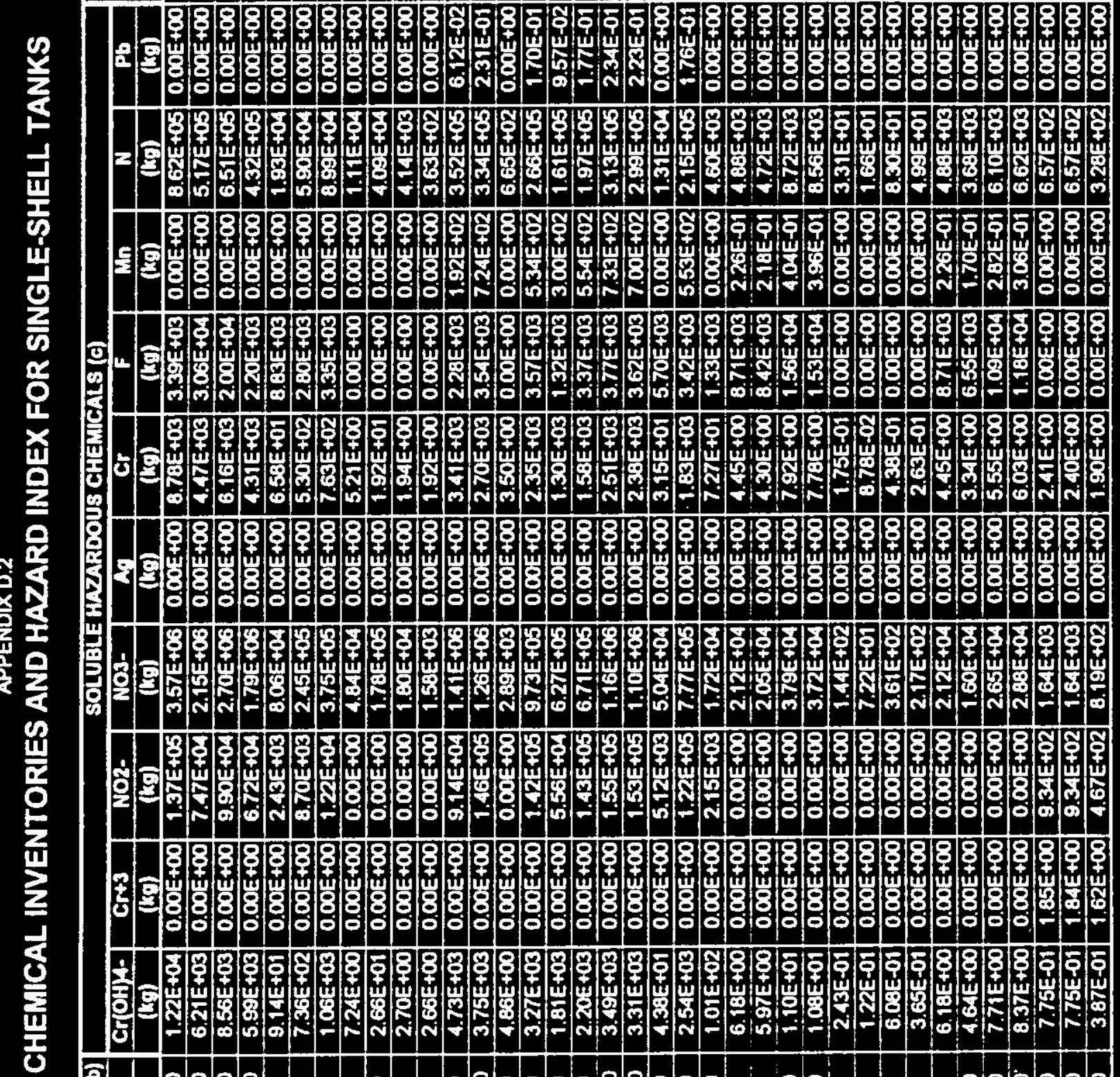

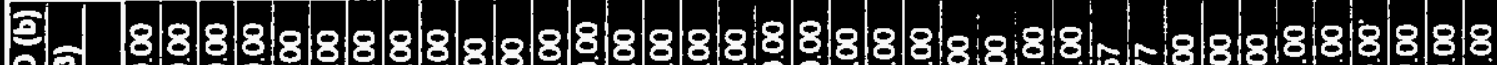

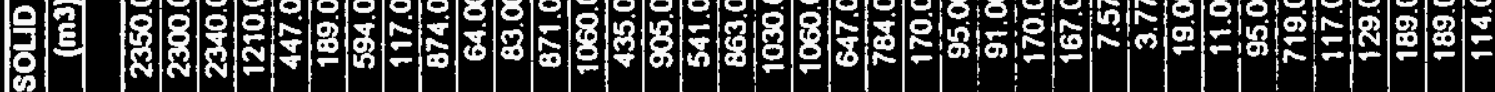


APPENDIX 0.2

\section{SOLUBLE CHEMICAL INVENTORIES AND HAZARD INDEX FOR SINGLE-SHELL TANKS}

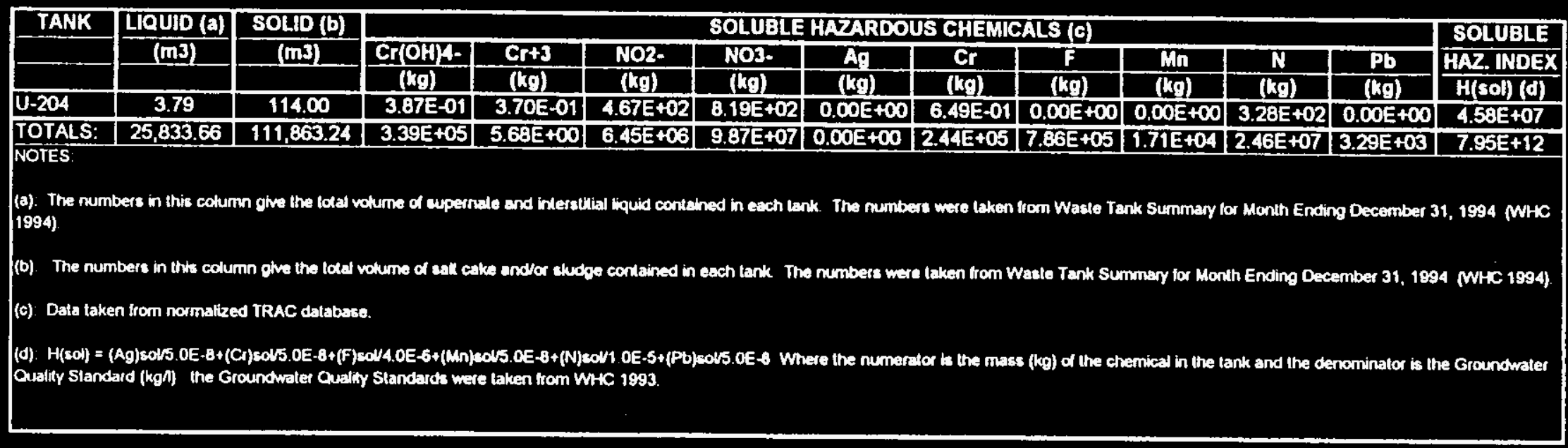


WHC-SD-WM-TI-711

Revision 0

This page intentionally left blank.

D-18 
WHC-SD-WM-T1-711

Revision 0

APPENDIX E

CURRENT WASTE VOLUMES AND RADIOLOGICAL

PARAMETERS FOR HANFORD

SINGLE-SHELL TANKS

E-1 
WHC-SD-WM-TI-711

Revision 0

This page intentionally left blank. 
WHC-SD-WM-TI-711

Revision 0

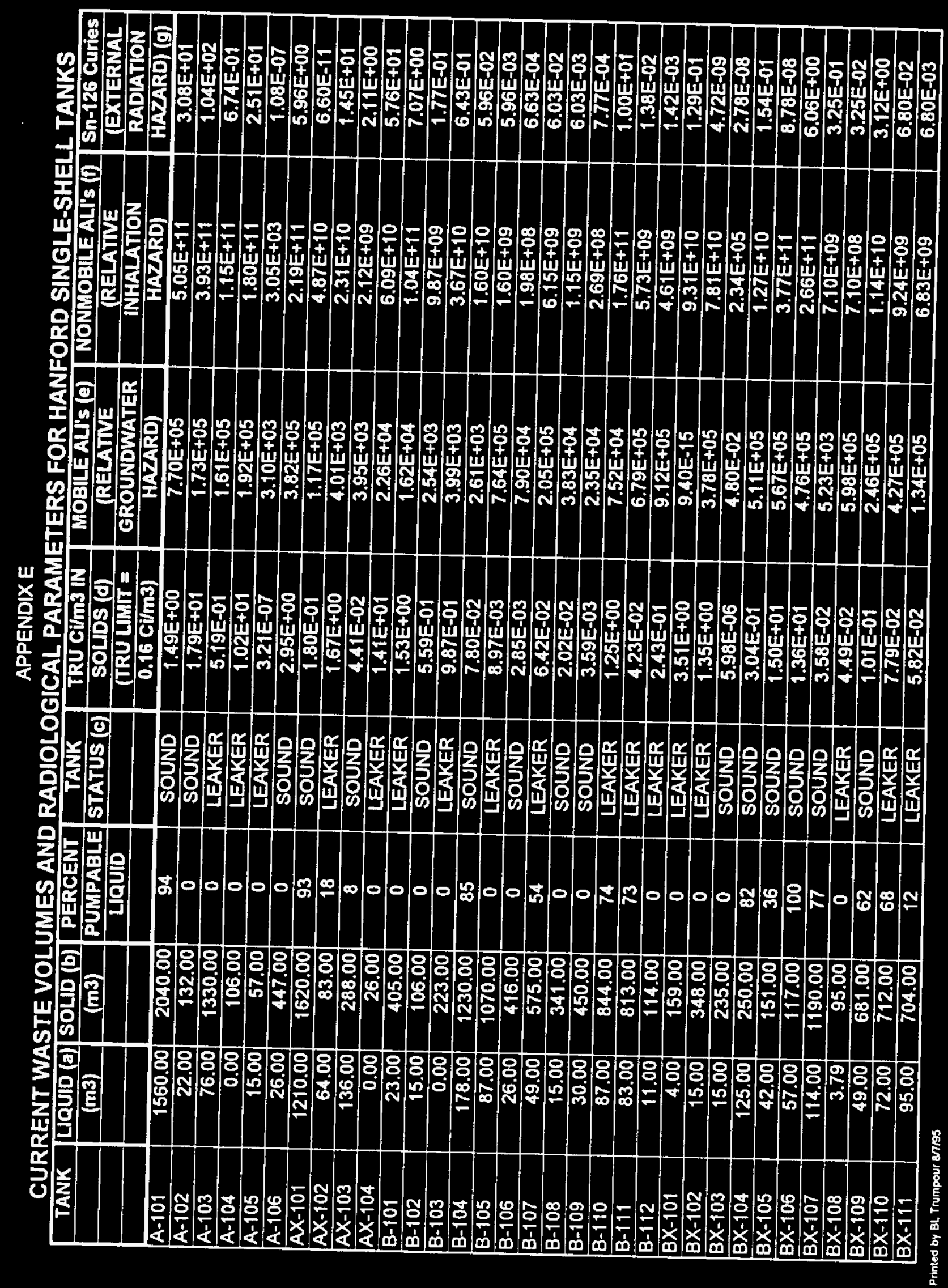




\section{APPENDIXE}

CURRENT WASTE VOLUMES AND RADIOLOGICAL PARAMETERS FOR HANFORD SINGLE-SHELL TANKS

\begin{tabular}{|c|c|c|c|c|c|c|c|c|}
\hline TANK & LIQUD (a) & SOLIO (b) & PERCENT & TANK & TRU Cilm3 IN & MOBLE ALPS $(\theta)$ & NONMOBILE AUPS (i) & Sn-126 Curies \\
\hline & $(\mathrm{m} 3)$ & $(\mathrm{m} 3)$ & PUMPABLE & STATUS (C) & SOLIDS (d) & (RELATIVE & (RELATVE & (EXTERNAL \\
\hline & & & LIQUID & & (TRU LLMIT $=$ & GROUNDWATER & TNHALATION & RADIATION \\
\hline & & & & & $0.16 \mathrm{Cl} / \mathrm{m} 3)$ & HAZARD) & HAZARD & HAZARD) (g) \\
\hline BX-112 & 30.00 & 594.00 & 25 & SOUND & $2.18 E-02$ & $1.48 E+04$ & $2.16 E+09$ & $5.73 E-02$ \\
\hline BY-101 & 19.00 & 1450.00 & 0 & SOUND & 3.47E-02 & $5.13 E+05$ & $8.39 E+09$ & 2.09E-03 \\
\hline$B Y-102$ & 110.00 & 1180.00 & 24 & SOUND & $1.23 E-02$ & $9.47 E+04$ & $2.43 E+09$ & 2.09E-04 \\
\hline BY-103 & 606.00 & 908.00 & 86 & LEAKER & $1.13 E+00$ & $6.51 E+04$ & $1.72 E+11$ & 5.265-01 \\
\hline BY-104 & 68.00 & 1470.00 & 0 & SOUND & $1.89 E-01$ & $4.14 E+06$ & $4.63 E+10$ & $6.00 E+00$ \\
\hline BY-105 & 727.00 & 1180.00 & 88 & LEAKER & $1.51 \mathrm{E}-01$ & 1.25E+05 & $2.97 E+10$ & $4.32 E+00$ \\
\hline BY-106 & 890.00 & 1450.00 & 91 & LEAKER & $7.32 \xi-02$ & $1.31 E+05$ & $1.77 E+10$ & $1.38 E+00$ \\
\hline BY-107 & 95.00 & 912.00 & 0 & LEAKER & 7.65E-02 & $5.20 E+05$ & $1.16 E+10$ & $1.16 E+00$ \\
\hline BY-108 & 34.00 & 839.00 & $\overline{0}$ & LEAKER & $1.06 E-01$ & $5.12 E+06$ & $1.48 E+10$ & $1.41 E+00$ \\
\hline BY-109 & 269.00 & 1330.00 & 61 & SOUND & $1.23 E-02$ & $1.98 E+06$ & $2.72 E+09$ & $1.655-08$ \\
\hline BY-110 & 34.00 & 1470.00 & 0 & SOUND & 8.67E-02 & $1.52 E+05$ & $2.12 \mathrm{E}+10$ & $1.96 E+00$ \\
\hline BY-111 & 0.00 & 1740.00 & 0 & SOUND & $2.98 E-02$ & $6.23 E+05$ & $8.64 E+09$ & $1.23 E-02$ \\
\hline BY-112 & 30.00 & 1070.00 & $\mathbf{0}$ & SOUND & $8.825-03$ & $1.36 E+05$ & 1.57E+09 & 1.05E-08 \\
\hline C.101 & 11.00 & 320.00 & $\mathbf{0}$ & LEAKER & 4.75E-01 & $6.32 \mathrm{E}+04$ & $2.53 E+10$ & $9.11 E+00$ \\
\hline C-102 & 113.00 & 1480.00 & 80 & SOUND & $1.84 E+00$ & $6.64 E+04$ & $4.53 \mathrm{E}+11$ & $1.11 E+01$ \\
\hline $\mathrm{C}-103$ & 503.00 & 235.00 & 100 & SOUND & $1.65 E+00$ & $1.85 E+05$ & $6.45 \mathrm{E}+10$ & $1.74 E+00$ \\
\hline C-104 & 42.00 & 1070.00 & 45 & SOUND & $1.14 E+00$ & $1.79 E+04$ & $2.04 E+11$ & $3.17 E+00$ \\
\hline $\mathrm{C}-105$ & 53.00 & 458.00 & 57 & SOUND & $1.70 E+01$ & $3.87 E+05$ & $1.29 E+12$ & $6.03 E+01$ \\
\hline $\mathrm{C}-106$ & 182.00 & 685.00 & 88 & SOUND & 7.97E-01 & $1.59 E+06$ & $9.10 E+10$ & $1.06 E+01$ \\
\hline C-107 & 95.00 & 945.00 & 76 & SOUND & $3.42 E-01$ & $7.53 E+05$ & $5.38 E+10$ & $2.25 E+00$ \\
\hline C-108 & 0.00 & 250.00 & 0 & SOUND & 4.40E-01 & $9.71 E+05$ & $1.83 E+10$ & 8.71E-01 \\
\hline C-109 & 15.00 & 235.00 & 0 & SOUND & 4.04E-03 & $1.65 E+06$ & $1.58 E+08$ & 3.45E-02 \\
\hline C-110 & 15.00 & 692.00 & 50 & LEAKER & 1.86E-01 & $2.78 E+05$ & $2.15 E+10$ & 1.14E-01 \\
\hline C-111 & 0.00 & 216.00 & 0 & LEAKER & 3.55E-01 & $3.73 E+05$ & $1.28 E+10$ & $5.80 E-01$ \\
\hline C.112 & 121.00 & 272.00 & 81 & SOUND & $2.77 E-01$ & 1.55E+05 & $1.26 E+10$ & $6.065-01$ \\
\hline S-101 & 363.00 & 1250.00 & 94 & SOUND & $3.48 E-01$ & $3.13 E+04$ & $7.25 E+10$ & $4.66 E+00$ \\
\hline S-102 & 871.00 & 1210.00 & 90 & SOUND & 2.11E-02 & $2.37 E+04$ & $4.25 E+09$ & 4.42E-01 \\
\hline$S-103$ & 386.00 & 553.00 & 77 & SOUND & 5.14E-03 & $2.37 E+03$ & 4.74E+08 & $4.93 E-02$ \\
\hline S-104 & 110.00 & 1000.00 & 79 & LEAKER & $2.40 E-01$ & $1.61 E+03$ & $3.99 E+10$ & $4.09 E+00$ \\
\hline S-105 & 132.00 & 1590.00 & 37 & SOUND & $1.18 E-02$ & $2.74 E+05$ & $3.13 E+09$ & 3.99E-01 \\
\hline S-106 & 719.00 & 1090.00 & 88 & SOUND & $2.20 E-03$ & $4.40 E+04$ & $3.99 E+08$ & $5.03 E-02$ \\
\hline S-107 & 223.00 & 1200.00 & 88 & SOUND & 1.11E+00 & $2.66 E+03$ & $2.22 E+11$ & $6.70 E+00$ \\
\hline S-108 & 481.00 & 1810.00 & 98 & SOUND & 6.90E-02 & $2.34 E+05$ & $2.08 E+10$ & 7.14E-01 \\
\hline
\end{tabular}


APPENDIX E

CURRENT WASTE VOLUMES AND RADIOLOGICAL PARAMETERS FOR HANFORD SINGLE-SHELL TANKS

\begin{tabular}{|c|c|c|c|c|c|c|c|c|}
\hline TANK & LIQUD (a) & SOLD (b) & PERCENT & TANK & TRU CIIm3 IN & MOBILE ALI's (e) & NONMOBILE AL's (0) & Sn-126 Curies \\
\hline & (m3) & (m3) & PUMPABLE & STATUS (c) & SOLIDS (d) & (RELATIVE & (RELATIVE & EXTERNAL \\
\hline & & & LQUDD & & (TRU LIMIT = & GROUNDWATER & INHALATION & RADIATION \\
\hline & & & & & $0.16 \mathrm{c}(\mathrm{m} 3)$ & HAZARD) & HAZARD) & HAZARD) (g) \\
\hline S-109 & 534.00 & 1620.00 & 84 & SOUND & $8.05 E-02$ & $1.08 E+05$ & $2.17 E+10$ & $2.25 E+00$ \\
\hline$S=110$ & 416.00 & 1060.00 & 94 & SOUND & 1.21E-01 & $6.98 \mathrm{E}+04$ & $2.15 E+10$ & $2.71 E+00$ \\
\hline S-111 & 776.00 & 1480.00 & 65 & SOUND & $1.2225-02$ & $1.33 E+06$ & $3.00 E+09$ & 4.09E-01 \\
\hline $5-112$ & 416.00 & 1560.00 & 97 & SOUND & 4.24E-01 & $4.39 E+05$ & $1.10 E+11$ & $1.24 E+00$ \\
\hline SX-101 & 552.00 & 1170.00 & 85 & SOUND & $2.38 \mathrm{E}-01$ & $9.20 \mathrm{E}+04$ & $4.65 E+10$ & $5.66 \mathrm{E}+00$ \\
\hline $5 x-102$ & 693.00 & 1360.00 & 97 & SOUND & $2.12 E-02$ & $1.48 \mathrm{E}+05$ & $4.81 E+09$ & $5.63 E-01$ \\
\hline $5 X-103$ & 882.00 & 1590.00 & 91 & SOUND & $1.12 E+00$ & $4.04 E+05$ & $2.96 E+11$ & $4.93 E+00$ \\
\hline SX-104 & 761.00 & 1560.00 & 97 & LEAKER & $3.48 E-01$ & $4.35 E+05$ & $9.04 E+10$ & $5.23 E+00$ \\
\hline SX-105 & 988.00 & 1600.00 & 91 & SOUND & 4.03E-01 & $2.53 E+05$ & $1.07 E+11$ & 7.37E-01 \\
\hline SX-106 & 965.00 & 1070.00 & 91 & SOUND & $2.53 E-01$ & $5.86 E+04$ & $4.51 E+10$ & $8.88 E+00$ \\
\hline SX-107 & 19.00 & 375.00 & 0 & LEAKER & $1.50 E+00$ & $3.42 \mathrm{E}+05$ & $9.35 E+10$ & $1.25 E+01$ \\
\hline SX-108 & 19.00 & 310.00 & 0 & LEAKER & $1.95 E+00$ & $1.68 E+05$ & $1.01 \mathrm{E}+11$ & $1.37 E+01$ \\
\hline$S X-109$ & 38.00 & 908.00 & 0 & LEAKER & $3.33 \mathrm{E}-01$ & $1.16 E+05$ & $5.04 E+10$ & $7.27 E+\infty$ \\
\hline SX-110 & 0.00 & 235.00 & 0 & LEAKER & $3.11 E+00$ & $6.21 \mathrm{E}+04$ & $1.22 E+11$ & $1.63 E+01$ \\
\hline $5 x-111$ & 26.00 & 447.00 & $\overline{0}$ & LEAKER & $2.10 E+00$ & $1.73 E+05$ & $1.56 E+11$ & $1.69 E+01$ \\
\hline$S X-112$ & 11.00 & 337.00 & 0 & LEAKER & $1.13 E+00$ & $1.86 E+05$ & $6.36 E+10$ & $8.85 E+00$ \\
\hline $5 x-113$ & 0.00 & 98.00 & 0 & LEAKER & 8.81E-01 & $1.33 \mathrm{E}+05$ & $1.44 E+10$ & $2.26 E+00$ \\
\hline$s x-114$ & 53.00 & 632.00 & 0 & LEAKER & $1.47 \mathrm{E}+00$ & $1.77 \mathrm{E}+05$ & $1.55 E+11$ & $2.17 E+01$ \\
\hline $5 X-115$ & 0.00 & 45.00 & 0 & LEAKER & $4.75 E+00$ & $2.63 E+05$ & $3.56 E+10$ & $5.53 E+00$ \\
\hline$T-101$ & 64.00 & 322.00 & 0 & LEAKER & $1.83 \mathrm{E}-01$ & $3.61 E+04$ & $9.80 E+09$ & $3.75 E-08$ \\
\hline$T-102$ & 49.00 & 72.00 & 100 & SOUND & $1.39 \mathrm{~g}-02$ & $6.43 E+04$ & $1.67 E+08$ & $3.12=-09$ \\
\hline$T-103$ & 15.00 & 87.00 & 0 & LEAKER & $6.58 E-02$ & $2.20 E+05$ & $9.54 E+08$ & $1.75 E-03$ \\
\hline T-104 & 189.00 & 1490.00 & 88 & SOUND & $9.33 E-02$ & $5.41 E+02$ & $2.32 E+10$ & 3.59E-01 \\
\hline $1-105$ & 87.00 & 284.00 & 74 & SOUND & 6.16E-01 & $2.06 \mathrm{E}-02$ & $2.92 E+10$ & $1.73 E-01$ \\
\hline$[-106$ & 7.57 & 71.90 & 0 & LEAKER & 2.71E-01 & $2.83 E+01$ & $3.24 E+09$ & $1.92 E-02$ \\
\hline-107 & 83.00 & 598.00 & 73 & LEAKER & $6.87 E-02$ & $2.635-14$ & $6.84 E+09$ & $2.94 E-01$ \\
\hline-108 & 0.00 & 167.00 & 0 & LEAKER & $2.46 E-02$ & $5.12 E+01$ & $6.84 E+08$ & 2.94E-02 \\
\hline T-109 & 0.00 & 220.00 & 0 & LEAKER & 2.07E-03 & $1.97 E+03$ & $7.59 E+07$ & $3.27 E-03$ \\
\hline$[-110$ & 159.00 & 1280.00 & 86 & SOUND & $1.25 E-01$ & $2.36 E+02$ & $2.67 E+10$ & $4.12 E-02$ \\
\hline$[-111$ & 189.00 & 1530.00 & 88 & LEAKER & $8.00 \mathrm{E}-02$ & $1.63 \mathrm{E}+01$ & $2.04 E+10$ & $3.92 E-02$ \\
\hline$[-112$ & 26.00 & 227.00 & 100 & SOUND & $9.20 \mathrm{E}-01$ & $1.52 \mathrm{E}+04$ & $3.48 E+10$ & $5.39 E-02$ \\
\hline$x-101$ & 19.00 & 310.00 & 0 & SOUND & 3.52E-06 & $9.69 E+04$ & $1.82 E+05$ & $6.43 E-09$ \\
\hline$x-102$ & 83.00 & 738.00 & 0 & SOUND & $5.29 E-07$ & $2.81 E+04$ & $6.51 E+04$ & $7.81 \mathrm{E}-10$ \\
\hline
\end{tabular}




\section{APPENDIXE}

CURRENT WASTE VOLUMES AND RADIOLOGICAL PARAMETERS FOR HANFORD SINGLE-SHELL TANKS

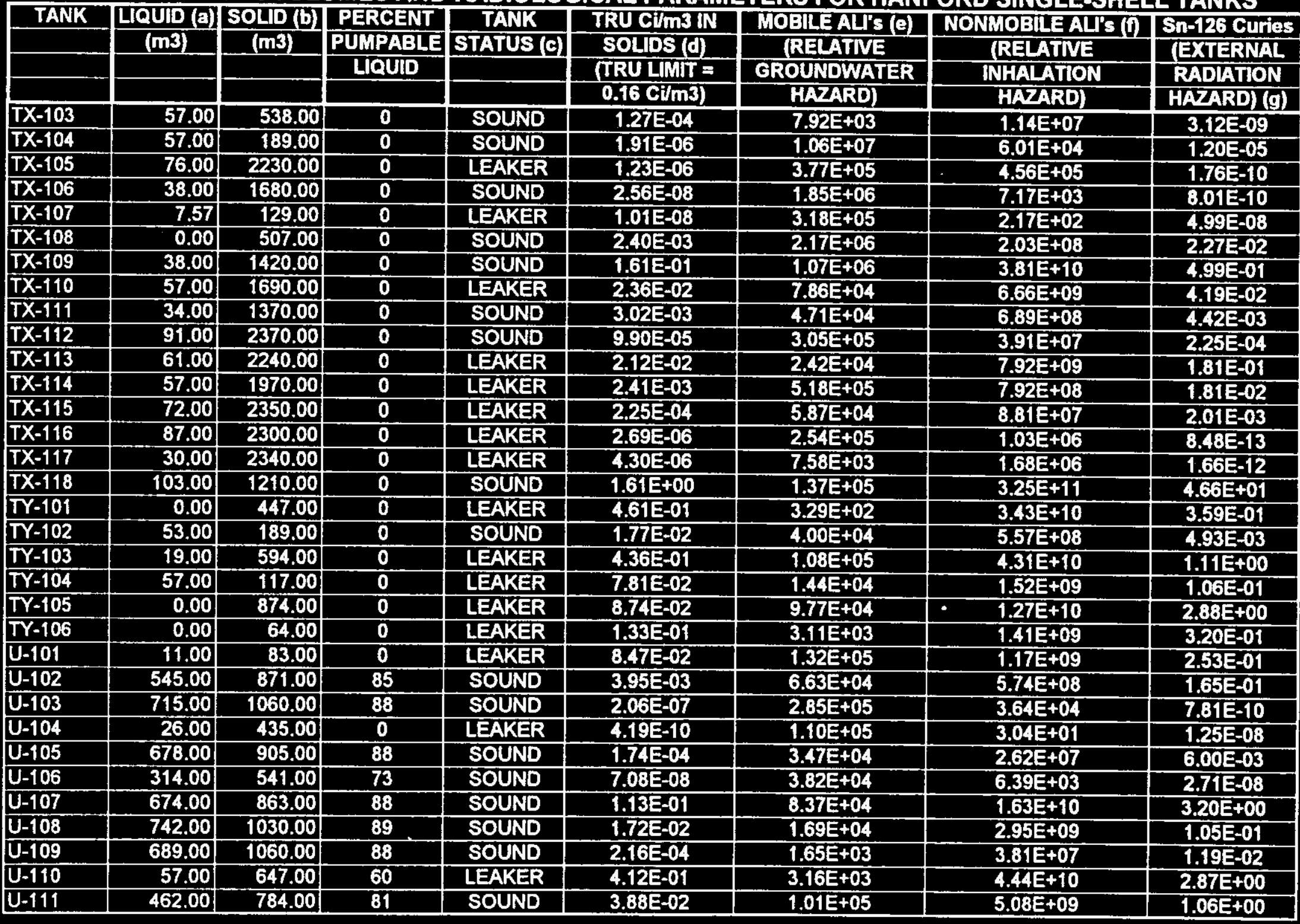


APPENDIXE

CURRENT WASTE VOLUMES AND RADIOLOGICAL PARAMETERS FOR HANFORD SINGLE-SHELL TANKS

\begin{tabular}{|c|c|c|c|c|c|c|c|c|}
\hline TANK & LIQUD (a) & SOLID (b) & PERCENT & TANK & TRU Ci/m3 IN & MOBILE ALIS' (e) & NONWOBILE ALPS (b) & Sn-126 Curies \\
\hline & (m3) & $(\mathrm{m} 3)$ & PUMPABLE & STATUS (c) & SOLIDS (d) & (RELATIVE & (RELATIVE & (EXTERNAL \\
\hline & & & LQQUID & & (TRU LIMIT = & GROUNDWATER & INHALATION & RADIATION \\
\hline & & & & & $0.16 \mathrm{C} / \mathrm{m} 3 \mathrm{~s}$ & HAZARD) & HAZARDI & HAZARD) (g) \\
\hline U-112 & 15.00 & 170.00 & $\mathbf{0}$ & LEAKER & $3.21 E-03$ & $2.54 E+05$ & $9.11 E+07$ & 2.26E-02 \\
\hline B-201 & 15.00 & 95.00 & 0 & LEAKER & $0.00 E+00$ & $2.23 E+05$ & $0.00 E+00$ & $0.00 E+00$ \\
\hline B-202 & 11.00 & 91.00 & $\mathbf{0}$ & SOUND & $2.43 E+00$ & $8.02 E+05$ & $3.69 E+10$ & $0.00 E+00$ \\
\hline B-203 & 23.00 & 170.00 & o & LEAKER & $4.21 E-03$ & $5.15 E+05$ & $1.19 E+08$ & $0.00 E+00$ \\
\hline$B-204$ & 23.00 & 167.00 & 0 & LEAKER & $4.29 \mathrm{E}-02$ & $9.25 E+04$ & $1.19 E+09$ & $0.00 E+00$ \\
\hline$C-201$ & 0.00 & 7.57 & 0 & LEAKER & $3.23 E-03$ & $2.49 E+04$ & $4.07 E+06$ & $2.70 E-03$ \\
\hline $\mathrm{C}-202$ & 0.00 & 3.77 & 0 & LEAKER & $1.78 E-02$ & $1.33 E+04$ & $1.12 E+07$ & $7.44 \mathrm{E}-03$ \\
\hline $\mathrm{C}-203$ & 0.00 & 19.00 & 0 & LEAKER & $3.54 E-04$ & $1.09 E+05$ & 1.12E+06 & 7.44E-04 \\
\hline C-204 & 0.00 & 11.00 & 0 & LEAKER & $2.15 E-06$ & $1.63 E+05$ & $3.95 E+03$ & $2.82 \mathrm{E}-06$ \\
\hline$T-201$ & 15.00 & 95.00 & $\mathbf{0}$ & SOUND & $0.00 E+00$ & $1.48 E+03$ & $0.00 E+00$ & $0.00 E+00$ \\
\hline$T-202$ & 7.57 & 719.00 & 0 & SOUND & $4.24 E-04$ & $1.72 E-02$ & $5.08 E+07$ & $0.00 E+00$ \\
\hline$T-203$ & 15.00 & 117.00 & 0 & SOUND & 2.61E-02 & $2.20 E+04$ & $5.08 E+08$ & $0.00 E+00$ \\
\hline$T-204$ & 15.00 & 129.00 & 0 & SOUND & $0.00 E+00$ & $2.76 E+05$ & $0.00 E+00$ & $0.00 E+00$ \\
\hline $\mathrm{U}-201$ & 3.79 & 189.00 & 0 & SOUND & $4.69 \mathrm{E}-07$ & $1.32 E+05$ & $1.48 E+04$ & $9.92 \mathrm{E}-11$ \\
\hline $\mathrm{U}-202$ & 3.79 & 189.00 & 0 & SOUND & 4.37E-07 & $3.33 E+04$ & $1.38 E+04$ & $1.07 E-14$ \\
\hline U-203 & 3.79 & 114.00 & $\overline{0}$ & SOUND & $6.69 E-07$ & $1.40 E+04$ & $1.27 E+04$ & $4.96 \mathrm{E}-11$ \\
\hline U-204 & 3.79 & 114.00 & $\overline{0}$ & SOUND & 2.09E-07 & $4.63 E+03$ & $3.97 E+03$ & $3.13 E-11$ \\
\hline TOTALS: & 25833.66 & 111863.24 & $78 \%$ & & & $5.57 E+07$ & $8.00 E+12$ & $5.94 E+02$ \\
\hline \multirow{2}{*}{\multicolumn{9}{|c|}{ SUBTOTALS BY TANK FARM: }} \\
\hline & & & & & & & & \\
\hline$\frac{\text { A FARM }}{\text { AXFARM }}$ & 1699.00 & 4112.00 & $87 \%$ & & & $1.68 E+06$ & $1.41 E+12$ & $1.66 E+02$ \\
\hline $\begin{array}{l}\text { AXFARM } \\
\text { B FARM }\end{array}$ & 1410.00 & 2017.00 & $82 \%$ & & & $1.47 \mathrm{E}+05$ & $1.35 E+11$ & $7.43 E+01$ \\
\hline $\begin{array}{l}\text { BFARM } \\
\text { BXFARM }\end{array}$ & 676.00 & 7110.00 & $45 \%$ & & & $4.43 E+06$ & $4.00 E+11$ & $1.81 \mathrm{E}+01$ \\
\hline $\begin{array}{l}\text { BXFARM } \\
\text { BY FARM }\end{array}$ & 621.79 & 5236.00 & $58 \%$ & & & $3.36 E+06$ & $8.64 E+11$ & $9.95 E+00$ \\
\hline $\begin{array}{l}\text { BY FARM } \\
\text { CFARM }\end{array}$ & 2882.00 & 14999.00 & $75 \%$ & & & 1.36E+07 & $3.37 E+11$ & $1.68 E+01$ \\
\hline$\frac{C \text { FARM }}{\text { SFARM }}$ & 1150.00 & 6899.34 & $85 \%$ & & & $6.81 E+06$ & 2.25E+12 & 9.25E+01 \\
\hline$\frac{\text { SFARM }}{\text { SXFARM }}$ & 5427.00 & 15423.00 & $84 \%$ & & & $2.56 E+06$ & $5.20 E+11$ & $2.37 E+01$ \\
\hline$\frac{\text { SXFARM }}{\text { T FARM }}$ & 5007.00 & 11737.00 & $89 \%$ & & & $3.01 E+06$ & $1.38 E+12$ & $1.31 E+02$ \\
\hline$\frac{\text { FARM }}{\text { XFARM }}$ & 921.14 & 7408.90 & $73 \%$ & & & $6.38 E+05$ & $1.57 \mathrm{E}+11$ & $1.01 E+00$ \\
\hline$\frac{\text { IX FARM }}{\text { IYFARM }}$ & 967.57 & 25581.00 & $0 \%$ & & & $1.79 \mathrm{E}+07$ & $3.79 E+11$ & $4.73 E+01$ \\
\hline JFARM & $\begin{aligned} 129.00 \\
494316\end{aligned}$ & 2285.00 & $0 \%$ & & & 2.63E+05 & $9.37 E+10$ & $4.78 E+00$ \\
\hline & & & $85 \%$ & & & 1.31E+06 & $7.06 E+10$ & $7.69 E+00$ \\
\hline
\end{tabular}




\section{APPENDIXE}

CURRENT WASTE VOLUMES AND RADIOLOGICAL PARAMETERS FOR HANFORD SINGLE-SHELL TANKS

\begin{tabular}{|c|c|c|c|c|c|c|c|c|}
\hline TANK & LIQUID a & SOLD (b) & PERCENT & TANK & TRU CI/m3IN & MOBILE AL'S (e) & NONMOBILE ALIS (0) & Sn-126 Curies \\
\hline & $(m 3)$ & (m3) & PUMPAELE & STATÚS (c) & SOLDS (d) & (RELATIVE & (RALATIVE & (EXTERNAL \\
\hline & & & LQUंD & & (TRU LIMTI = & GROUNDWATER & NAALATION & RADATION \\
\hline & & & & & $0.16 \mathrm{CI} / \mathrm{m} 3$ & HAZARD & HAZARD & HAZARD (a) \\
\hline
\end{tabular}

NOTES:

(a): The numbers in this column give the total volume of supernate and interstitial liquid contained in each tank. The numbers were taken from Waste Tank Summary for Month Ending December 31, 1994 (WHC 1994).

(b): The numbers in this column give the total volume of salt cake and/or sludge contained in each tank. The numbers were taken from Waste Tank Summary for Month Ending December 31, 1994 (WHC 1994).

(c): The designation LEAKER includes assumed leakers and confirmed leakers.

(d): The regulatory TRU level is $100 \mathrm{nCi} / \mathrm{g}$, which converts to $0.16 \mathrm{Ci} / \mathrm{m} 3$ assuming a density of $1.6 \mathrm{~g} / \mathrm{cc}$ (Hanford Soil). The $0.16 \mathrm{Ci} / \mathrm{m} 3$ is also the TRU limit for simple, shallow land burial, in accordance with WHC-EP-0063-3.

(e): The mobile radionuclide species include Se-79, Tc-99, l-129 and Uranium in the liquid fraction of the waste, which could migrate freely through the vadose zone. The number in this column indicates the relative hazard to the groundwater presented by the tank.

(i): The number in this column actually represents the total relative hazard with respect to all pathways other than the groundwater pathway. It is labeled "relative inhalation hazard" because most of the dose is through inhalation. The number also represents most of the hazard presented by the tank after pumping has been accomplished. Pumping may reduce the solid ALl's to some extent, depending on the resuspension during the pumping process.

(g) Sn-126 is the bounding radionuclide for long-term extemal radiation. 
WHC-SD-WM-TI-711

Revision 0

\author{
APPENDIX F \\ RANKING OF SINGLE-SHELL TANKS BY \\ NONMOBILE ALIs; CUMULATIVE PERCENT \\ OF NONMOBILE ALIs
}


WHC-SD-WM-TI-711

Revision 0

This page intentionally left blank. 
WHC-SD-WM-TI-711

Revision 0

APPENDIX F

RANKING OF SINGLE-SHELL TANKS BY NONMOBILE ALI'S;

CUMULATIVE PERCENT OF NONMOBILE ALII'S

\begin{tabular}{|c|c|c|}
\hline TANK & NONMOBILE ALI'S & \% SOLID \\
\hline & (RELATIVE INHALATION HAZARD) & ALI's CUM. \\
\hline C-105 & $1.29 E+12$ & $16.17 \%$ \\
\hline A-101 & $5.05 E+11$ & $22.49 \%$ \\
\hline C.102 & 4.53E+11 & $28.15 \%$ \\
\hline A-102 & $3.93 E+11$ & $33.06 \%$ \\
\hline BX-105 & $3.77 E+11$ & $37.78 \%$ \\
\hline $\bar{T}-118$ & $3.25 E+11$ & $41.84 \%$ \\
\hline SX-103 & $2.96 E+11$ & $45.54 \%$ \\
\hline $\mathrm{BX}-106$ & $2.66 E+11$ & $48.86 \%$ \\
\hline S-107 & $2.22 E+11$ & $51.64 \%$ \\
\hline A-106 & $2.19 E+11$ & $54.38 \%$ \\
\hline C-104 & $2.04 E+11$ & $56.92 \%$ \\
\hline A-104 & $1.80 E+11$ & $59.17 \%$ \\
\hline$B-110$ & $1.76 E+11$ & $61.37 \%$ \\
\hline BY-103 & $1.72 E+11$ & $63.52 \%$ \\
\hline$S X-111$ & $1.56 E+11$ & $65.47 \%$ \\
\hline $5 x-114$ & $1.55 E+11$ & $67.41 \%$ \\
\hline SX-110 & $1.22 E+11$ & $68.93 \%$ \\
\hline A-103 & $1.15 E+11$ & $70.37 \%$ \\
\hline S-112 & $1.10 E+11$ & $71.74 \%$ \\
\hline SX-105 & $1.07 E+11$ & $73.09 \%$ \\
\hline B-101 & $1.04 E+11$ & $74.38 \%$ \\
\hline SX-108 & $1.01 E+11$ & $75.64 \%$ \\
\hline SX-107 & $9.35 E+10$ & $76.81 \%$ \\
\hline BX-101 & $9.31 E+10$ & $77.97 \%$ \\
\hline $\mathrm{C}-106$ & $9.10 E+10$ & $79.11 \%$ \\
\hline SX-104 & $9.04 E+10$ & $80.24 \%$ \\
\hline$\overline{B X}-102$ & $7.81 E+10$ & $81.22 \%$ \\
\hline S-101 & $7.25 E+10$ & $82.12 \%$ \\
\hline C-103 & $6.45 E+10$ & $82.93 \%$ \\
\hline$s x-112$ & $6.36 E+10$ & $83.72 \%$ \\
\hline$\overline{A x-104}$ & $6.09 E+10$ & $84.48 \%$ \\
\hline C-107 & $5.38 E+10$ & $85.16 \%$ \\
\hline SX-109 & $5.04 E+10$ & $85.79 \%$ \\
\hline$A x-101$ & 4.87E+10 & $86.40 \%$ \\
\hline SX-101 & 4.65E+10 & $86.98 \%$ \\
\hline BY-104 & $4.63 \mathrm{E}+10$ & $87.56 \%$ \\
\hline $5 X-106$ & $4.51 E+10$ & $88.12 \%$ \\
\hline $\mathrm{U}-110$ & $4.44 E+10$ & $88.67 \%$ \\
\hline TY-103 & $4.31 E+10$ & $89.21 \%$ \\
\hline S-104 & $3.99 E+10$ & $89.71 \%$ \\
\hline$T X-109$ & $3.81 E+10$ & $90.19 \%$ \\
\hline $8-202$ & $3.69 E+10$ & $90.65 \%$ \\
\hline B-103 & $3.67 E+10$ & $91.11 \%$ \\
\hline $5 x-115$ & $3.56 E+10$ & $91.55 \%$ \\
\hline$T-112$ & $3.48 E+10$ & $91.99 \%$ \\
\hline$T Y=101$ & $3.43 E+10$ & $92.42 \%$ \\
\hline
\end{tabular}


WHC-SD-WM-TI-711

Revision 0

APPENDIX F

RANKING OF SINGLE-SHELL TANKS BY NONMOBILE ALI'S; CUMULATIVE PERCENT OF NONMOBILE ALI'S

\begin{tabular}{|c|c|c|}
\hline TANK & NONMOBILE ALIS & $\%$ SOLID \\
\hline & (RELATIVE INHALATION HAZARD) & ALI's CUM. \\
\hline BY-105 & $2.975+10$ & $92.79 \%$ \\
\hline$T-105$ & $2.92 E+10$ & $93.15 \%$ \\
\hline$T-110$ & $2.67 E+10$ & $93.49 \%$ \\
\hline C-101 & $2.53 E+10$ & $93.80 \%$ \\
\hline$T=104$ & $2.32 E+10$ & $94.09 \%$ \\
\hline$\overline{A x}-102$ & $2.311+10$ & $94.38 \%$ \\
\hline S-109 & $2.176+10$ & $94.65 \%$ \\
\hline C.110 & $2.15 E+10$ & $94.92 \%$ \\
\hline $5-110$ & $2.15 E+10$ & $95.19 \%$ \\
\hline BY-110 & $2.12 E+10$ & $95.46 \%$ \\
\hline S-108 & $2.08 \mathrm{E}+10$ & $95.72 \%$ \\
\hline$T-111$ & $2.04 E+10$ & $95.97 \%$ \\
\hline C-108 & $1.83 E+10$ & $96.20 \%$ \\
\hline BY-106 & $1.77 E+10$ & $96.42 \%$ \\
\hline U-107 & $1.63 E+10$ & $96.62 \%$ \\
\hline B-104 & $1.60 E+10$ & $96.82 \%$ \\
\hline BY-108 & $1.48 E+10$ & $97.01 \%$ \\
\hline SX-113 & $1.44 E+10$ & $97.19 \%$ \\
\hline $\mathrm{C}-111$ & $1.28 \mathrm{E}+10$ & $97.35 \%$ \\
\hline$T Y-105$ & $1.27 E+10$ & $97.51 \%$ \\
\hline$B \times-104$ & $1.27 E+10$ & $97.67 \%$ \\
\hline C-112 & $1.265+10$ & $97.82 \%$ \\
\hline BY-107 & $1.16 E+10$ & $97.97 \%$ \\
\hline BX-109 & $1.14 E+10$ & $98.11 \%$ \\
\hline B-102 & $9.87 E+09$ & $98.23 \%$ \\
\hline T-101 & $9.80 E+09$ & $98.36 \%$ \\
\hline$B x-110$ & $9.24 \mathrm{E}+09$ & $98.47 \%$ \\
\hline BY-111 & $8.64 E+09$ & $98.58 \%$ \\
\hline BY-101 & $8.39 E+09$ & $98.68 \%$ \\
\hline$T x-113$ & $7.921+09$ & $98.78 \%$ \\
\hline$B X-107$ & $7.10 E+09$ & $98.87 \%$ \\
\hline T-107 & $6.84 E+09$ & $98.96 \%$ \\
\hline$B X-111$ & $6.83 E+09$ & $99.04 \%$ \\
\hline$T x-110$ & $6.66 \mathrm{E}+09$ & $99.13 \%$ \\
\hline B-107 & $6.15 E+09$ & $99.20 \%$ \\
\hline$B-111$ & $5.73 E+09$ & $99.27 \%$ \\
\hline$U-111$ & $5.08 \mathrm{E}+09$ & $99.34 \%$ \\
\hline SX-102 & $4.81 E+09$ & $99.40 \%$ \\
\hline$B-112$ & $4.61 E+09$ & $99.46 \%$ \\
\hline S-102 & $4.25 E+09$ & $99.51 \%$ \\
\hline$T-106$ & $3.24 \mathrm{E}+09$ & $99.55 \%$ \\
\hline S-105 & $3.13 \mathrm{E}+09$ & $99.59 \%$ \\
\hline S-111 & $3.00 E+09$ & $99.63 \%$ \\
\hline U-108 & $2.95 E+09$ & $99.66 \%$ \\
\hline BY-109 & $2.72 \mathrm{E}+09$ & $99.70 \%$ \\
\hline BY-102 & $2.43 E+09$ & $99.73 \%$ \\
\hline
\end{tabular}


WHC-SD-WM-TI-711

Revision 0

APPENDIX F

RANKING OF SINGLESHELL TANKS BY NONMOEILE AL'S; CUMULATIVE PERCENT OF NONMOBILE ALI'S

\begin{tabular}{|c|c|c|}
\hline TANR & NONMOBILE ALI'S & $\%$ SOLID \\
\hline & (RELATIVE INHALATION HAZARD) & ALI's CUM. \\
\hline $8 X-112$ & $2.16 E+09$ & $99.75 \%$ \\
\hline$\overline{A X-103}$ & $2.12 E+09$ & $99.78 \%$ \\
\hline B-105 & $1.60 E+09$ & $99.80 \%$ \\
\hline BY-112 & 1.57E+09 & $99.82 \%$ \\
\hline$T Y \cdot 104$ & $1.52 E+09-$ & $99.84 \%$ \\
\hline$\overline{T Y}-106$ & 1.41E+09 & $99.86 \%$ \\
\hline $8-204$ & $1.19 E+09$ & $99.87 \%$ \\
\hline U-101 & 1.17E+09 & $99.89 \%$ \\
\hline 8-108 & $1.15 E+09$ & $99.90 \%$ \\
\hline$T-103$ & $9.54 E+08$ & $99.91 \%$ \\
\hline $\mathrm{T}-114$ & $7.92 E+08$ & $99.92 \%$ \\
\hline BX-108 & $7.10 E+08$ & $99.93 \%$ \\
\hline$\overline{T X}-111$ & $6.89 E+08$ & $99.94 \%$ \\
\hline$T-108$ & $6.84 E+08$ & $99.95 \%$ \\
\hline U-102 & $5.74 E+08$ & $99.96 \%$ \\
\hline TY-102 & $5.57 E+08$ & $99.96 \%$ \\
\hline$T-203$ & $5.08 E+08$ & $99.97 \%$ \\
\hline S-103 & 4.74E+08 & $99.98 \%$ \\
\hline S-106 & $3.99 E+08$ & $99.98 \%$ \\
\hline B-109 & $2.69 E+08$ & $99.98 \%$ \\
\hline$T X-108$ & $2.03 E+08$ & $99.99 \%$ \\
\hline B-106 & $1.98 E+08$ & $99.99 \%$ \\
\hline$T-102$ & 1.67E+08 & $99.99 \%$ \\
\hline C-109 & $1.58 E+08$ & $99.99 \%$ \\
\hline B-203 & $1.19 E+08$ & $99.99 \%$ \\
\hline $\mathrm{U}-112$ & $9.11 E+07$ & $100.00 \%$ \\
\hline$T X-115$ & $8.81 E+07$ & $100.00 \%$ \\
\hline$T-109$ & $7.59 E+07$ & $100.00 \%$ \\
\hline$T-202$ & $5.08 E+07$ & $100.00 \%$ \\
\hline$T X-112$ & 3.91E+07 & $100.00 \%$ \\
\hline U-109 & $3.81 E+07$ & $100.00 \%$ \\
\hline U-105 & $2.62 E+07$ & $100.00 \%$ \\
\hline$T x-103$ & $1.14 E+07$ & $100.00 \%$ \\
\hline $\mathrm{C}-202$ & $1.12 E+07$ & $100.00 \%$ \\
\hline C-201 & 4.07E+06 & $100.00 \%$ \\
\hline$T X-117$ & $1.68 E+06$ & $100.00 \%$ \\
\hline C-203 & $1.12 E+06$ & $100.00 \%$ \\
\hline$T X-116$ & $1.03 E+06$ & $100.00 \%$ \\
\hline $\mathrm{TX}-105$ & $4.56 E+05$ & $100.00 \%$ \\
\hline$B X-103$ & 2.34E+05 & $100.00 \%$ \\
\hline$T X-101$ & $1.82 E+05$ & $100.00 \%$ \\
\hline$T X-102$ & $6.51 E+04$ & $100.00 \%$ \\
\hline$T X-104$ & $6.01 E+04$ & $100.00 \%$ \\
\hline U-103 & $3.64 E+04$ & $100.00 \%$ \\
\hline U-201 & $1.48 E+04$ & $100.00 \%$ \\
\hline U-202 & $1.38 E+04$ & $100.00 \%$ \\
\hline
\end{tabular}


WHC-SD-WM-TI-711

Revision 0

\section{APPENDIX $F$}

RANKING OF SINGLE-SHELL TANKS BY NONMOBILE ALI'S; CUMULATIVE PERCENT OF NONMOBILE ALI'S

\begin{tabular}{|l|c|c|}
\hline TANK & NONMOBILE ALI' & \% SOLID \\
\hline & (RELATIVE TNAALATION HAZARD) & ALPS CUM \\
\hline U-203 & $1.27 E+04$ & $100.00 \%$ \\
\hline TX-106 & $7.17 E+03$ & $100.00 \%$ \\
\hline$U-106$ & $6.39 E+03$ & $100.00 \%$ \\
\hline$U-204$ & $3.97 E+03$ & $100.00 \%$ \\
\hline$C-204$ & $3.95 E+03$ & $100.00 \%$ \\
\hline$A-105$ & $3.05 E+03$ & $100.00 \%$ \\
\hline$T X-107$ & $2.17 E+02$ & $100.00 \%$ \\
\hline$U-104$ & $3.04 E+01$ & $100.00 \%$ \\
\hline B-201 & $0.00 E+00$ & $100.00 \%$ \\
\hline T-201 & $0.00 E+00$ & $100.00 \%$ \\
\hline T-204 & $0.00 E+00$ & $100.00 \%$ \\
\hline TOTALS: & $8.00 E+12$ & \\
\hline
\end{tabular}


WHC-SD-WM-TI-711

Revision 0

APPENDIX F.1

RANKING OF SINGLE-SHELL TANKS BY INSOLUBLE CHEMICAL HAZARD

\begin{tabular}{|c|c|c|c|c|}
\hline TANK & LIQUDD & SOLID & INSOLUELE & CUMULATIVE \\
\hline & $(\mathrm{m} 3)$ & (m3) & HAZ. INDEX & $\%$ \\
\hline & & & $H($ insol) & \\
\hline S-104 & 110.00 & 1000.00 & $1.14 E+11$ & $8.46 \%$ \\
\hline $5 X-114$ & 53.00 & 632.00 & $1.09 E+11$ & $16.55 \%$ \\
\hline$S x-111$ & 26.00 & 447.00 & $1.07 E+11$ & $24.49 \%$ \\
\hline SX-101 & 552.00 & 1170.00 & $8.80 E+10$ & $31.02 \%$ \\
\hline C-109 & 15.00 & 235.00 & $8.76 E+10$ & $37.52 \%$ \\
\hline SX-109 & 38.00 & 908.00 & $8.59 E+10$ & $43.89 \%$ \\
\hline $5 x-108$ & 19.00 & 310.00 & $8.01 E+10$ & $49.83 \%$ \\
\hline SX-107 & 19.00 & 375.00 & $7.72 E+10$ & $55.56 \%$ \\
\hline $5 X-110$ & 0.00 & 235.00 & $7.41 E+10$ & $61.06 \%$ \\
\hline$S X-112$ & 11.00 & 337.00 & $6.97 E+10$ & $66.23 \%$ \\
\hline S-101 & 363.00 & 1250.00 & $4.92 E+10$ & $69.88 \%$ \\
\hline S-107 & 223.00 & 1200.00 & $4.83 E+10$ & $73.47 \%$ \\
\hline SX-102 & 693.00 & 1360.00 & $4.59 E+10$ & $76.88 \%$ \\
\hline SX-104 & 761.00 & 1560.00 & $4.49 E+10$ & $80.21 \%$ \\
\hline C-112 & 121.00 & 272.00 & $3.76 E+10$ & $83.00 \%$ \\
\hline Sx-105 & 988.00 & 1600.00 & $3.70 E+10$ & $85.75 \%$ \\
\hline$S-110$ & 416.00 & 1060.00 & $3.00 E+10$ & $87.98 \%$ \\
\hline $5 x-103$ & 882.00 & 1590.00 & $2.99 E+10$ & $90.20 \%$ \\
\hline S-111 & 776.00 & 1480.00 & $1.99 E+10$ & $91.68 \%$ \\
\hline$T X-101$ & 19.00 & 310.00 & $1.85 E+10$ & $93.05 \%$ \\
\hline$S x-115$ & 0.00 & 45.00 & $1.15 E+10$ & $93.90 \%$ \\
\hline S-108 & 481.00 & 1810.00 & $7.67 E+09$ & $94.47 \%$ \\
\hline S-102 & 871.00 & 1210.00 & $5.99 E+09$ & $94.92 \%$ \\
\hline S-112 & 416.00 & 1560.00 & $5.34 E+09$ & $95.31 \%$ \\
\hline U-111 & 462.00 & 784.00 & $3.63 E+09$ & $95.58 \%$ \\
\hline$T-111$ & 189.00 & 1530.00 & $3.33 E+09$ & $95.83 \%$ \\
\hline$B X-109$ & 49.00 & 681.00 & $3.24 E+09$ & $96.07 \%$ \\
\hline$T-104$ & 189.00 & 1490.00 & 2.25E+09 & $96.24 \%$ \\
\hline$U-112$ & 15.00 & 170.00 & $2.03 E+09$ & $96.39 \%$ \\
\hline $5 x-106$ & 965.00 & 1070.00 & $2.00 E+09$ & $96.54 \%$ \\
\hline$T-110$ & 159.00 & 1280.00 & $1.99 E+09$ & $96.68 \%$ \\
\hline C-102 & 113.00 & 1480.00 & $1.95 E+09$ & $96.83 \%$ \\
\hline$T X-109$ & 38.00 & 1420.00 & $1.83 E+09$ & $96.96 \%$ \\
\hline C-104 & 42.00 & 1070.00 & $1.69 E+09$ & $97.09 \%$ \\
\hline$B X-107$ & 114.00 & 1190.00 & $1.63 E+09$ & $97.21 \%$ \\
\hline$T X-113$ & 61.00 & 2240.00 & $1.23 E+09$ & $97.30 \%$ \\
\hline $8-110$ & 87.00 & 844.00 & $1.19 E+09$ & $97.39 \%$ \\
\hline$T X-106$ & 38.00 & 1680.00 & $1.19 E+09$ & $97.48 \%$ \\
\hline C-107 & 95.00 & 945.00 & $1.16 E+09$ & $97.56 \%$ \\
\hline B-111 & 83.00 & 813.00 & $1.10 E+09$ & $97.65 \%$ \\
\hline B-104 & 178.00 & 1230.00 & $1.09 E+09$ & $97.73 \%$ \\
\hline U-110 & 57.00 & 647.00 & $9.84 \mathrm{E}+08$ & $97.80 \%$ \\
\hline C- 110 & 15.00 & 692.00 & $8.86 E+08$ & $97.87 \%$ \\
\hline BY-110 & 34.00 & 1470.00 & $8.20 E+08$ & $97.93 \%$ \\
\hline B-107 & 49.00 & 575.00 & $7.78 E+08$ & $97.98 \%$ \\
\hline
\end{tabular}


WHC-SD-WM-TI-711

Revision 0

APPENDIX F.1

RANKING OF SINGLE-SHELL TANKS BY INSOLUBLE CHEMICAL HAZARD

\begin{tabular}{|c|c|c|c|c|}
\hline TANK & LIQUDD & SOLID & INSOLUBLE & CUMULATIVE \\
\hline & $(\mathrm{m} 3)$ & $(\mathrm{m} 3)$ & HAZ, INDEX & $\%$ \\
\hline & & & $H($ insol $)$ & \\
\hline$B X-110$ & 72.00 & 712.00 & $7.62 E+08$ & $98.04 \%$ \\
\hline S-105 & 132.00 & 1590.00 & $7.47 E+08$ & $98.10 \%$ \\
\hline BY-105 & 727.00 & 1180.00 & $6.97 E+08$ & $98.15 \%$ \\
\hline U-102 & 545.00 & 871.00 & $6.66 E+08$ & $98.20 \%$ \\
\hline BY-106 & 890.00 & 1450.00 & $6.59 E+08$ & $98.25 \%$ \\
\hline$\overline{B X}-112$ & 30.00 & 594.00 & $6.40 E+08$ & $98.29 \%$ \\
\hline BY-104 & 68.00 & 1470.00 & $6.33 E+08$ & $98.34 \%$ \\
\hline$T-107$ & 83.00 & 598.00 & $6.21 E+08$ & $98.39 \%$ \\
\hline $\mathrm{B}-203$ & 23.00 & 170.00 & $6.00 E+08$ & $98.43 \%$ \\
\hline BY-108 & 34.00 & 839.00 & $5.94 E+08$ & $98.48 \%$ \\
\hline C-106 & 182.00 & 685.00 & $5.91 E+08$ & $98.52 \%$ \\
\hline B-204 & 23.00 & 167.00 & $5.88 E+08$ & $98.56 \%$ \\
\hline$T X-115$ & 72.00 & 2350.00 & $5.76 E+08$ & $98.61 \%$ \\
\hline$T X-110$ & 57.00 & 1690.00 & $5.65 E+08$ & $98.65 \%$ \\
\hline C-105 & 53.00 & 458.00 & $5.62 E+08$ & $98.69 \%$ \\
\hline$T x-112$ & 91.00 & 2370.00 & $5.54 E+08$ & $98.73 \%$ \\
\hline$\overline{T X-105}$ & 76.00 & 2230.00 & $5.36 E+08$ & $98.77 \%$ \\
\hline $5 x-113$ & 0.00 & 98.00 & 5.31E+08 & $98.81 \%$ \\
\hline TY.105 & 0.00 & 874.00 & $5.25 E+08$ & $98.85 \%$ \\
\hline$T x-111$ & 34.00 & 1370.00 & 5.17E+08 & $98.89 \%$ \\
\hline$T-105$ & 87.00 & 284.00 & $4.95 E+08$ & $98.92 \%$ \\
\hline BY-107 & 95.00 & 912.00 & $4.925+08$ & $98.96 \%$ \\
\hline$T-112$ & 26.00 & 227.00 & $4.73 E+08$ & $98.99 \%$ \\
\hline$T-204$ & 15.00 & 129.00 & $4.56 E+08$ & $99.03 \%$ \\
\hline$T X-117$ & 30.00 & 2340.00 & $4.55 E+08$ & $99.06 \%$ \\
\hline$T X-118$ & 103.00 & 1210.00 & $4.30 E+08$ & $99.09 \%$ \\
\hline$T-203$ & 15.00 & 117.00 & $4.19 E+08$ & $99.13 \%$ \\
\hline$\overline{T x-116}$ & 87.00 & 2300.00 & $3.96 E+08$ & $99.15 \%$ \\
\hline$T X-114$ & 57.00 & 1970.00 & $3.88 E+08$ & $99.18 \%$ \\
\hline S-106 & 719.00 & 1090.00 & $3.66 E+08$ & $99.21 \%$ \\
\hline U-107 & 674.00 & 863.00 & $3.44 E+08$ & $99.24 \%$ \\
\hline B-201 & 15.00 & 95.00 & $3.36 E+08$ & $99.26 \%$ \\
\hline$T-201$ & 15.00 & 95.00 & $3.36 E+08$ & $99.29 \%$ \\
\hline$T Y-103$ & 19.00 & 594.00 & $3.30 E+08$ & $99.31 \%$ \\
\hline$\overline{B Y}-111$ & 0.00 & 1740.00 & $3.29 \mathrm{E}+08$ & $99.33 \%$ \\
\hline B-202 & 11.00 & 91.00 & $3.25 E+08$ & $99.36 \%$ \\
\hline BY-109 & 269.00 & 1330.00 & $3.25 E+08$ & $99.38 \%$ \\
\hline S-109 & 534.00 & 1620.00 & $3.14 E+08$ & $99.41 \%$ \\
\hline U.109 & 689.00 & 1060.00 & $3.12 E+08$ & $99.43 \%$ \\
\hline BY-101 & 19.00 & 1450.00 & $3.03 E+08$ & $99.45 \%$ \\
\hline A-101 & 1560.00 & 2040.00 & $3.02 E+08$ & $99.47 \%$ \\
\hline $\mathrm{C}-101$ & 11.00 & 320.00 & $3.01 E+08$ & $99.50 \%$ \\
\hline U-105 & 678.00 & 905.00 & $2.91 E+08$ & $99.52 \%$ \\
\hline U-108 & 742.00 & 1030.00 & $2.78 E+08$ & $99.54 \%$ \\
\hline BY.103 & 606.00 & 908.00 & $2.73 E+08$ & $99.56 \%$ \\
\hline
\end{tabular}

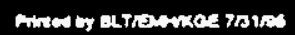


WHC-SD-WM-TI-711

Revision 0

APPENDIX F.1

RANKING OF SINGLE-SHELL TANKS BY INSOLUBLE CHEMICAL HAZARD

\begin{tabular}{|c|c|c|c|c|}
\hline TANK & LIQUID & SOLID & INSOLUBLE & CUMULATIVE \\
\hline & $(\mathrm{m} 3)$ & $(\mathrm{m} 3)$ & HAZ. INDEX & $\%$ \\
\hline & & & $H($ insol $)$ & \\
\hline U.103 & 715.00 & 1060.00 & $2.65 E+08$ & $99.58 \%$ \\
\hline $8 X-111$ & 95.00 & 704.00 & $2.62 E+08$ & $99.60 \%$ \\
\hline B-105 & 87.00 & 1070.00 & $2.59 E+08$ & $99.62 \%$ \\
\hline$T-202$ & 7.57 & 719.00 & $2.53 E+08$ & $99.64 \%$ \\
\hline BY-102 & 110.00 & 1180.00 & $2.35 E+08$ & $99.65 \%$ \\
\hline C.103 & 503.00 & 235.00 & $2.35 E+08$ & $99.67 \%$ \\
\hline$C-108$ & 0.00 & 250.00 & $2.35 E+08$ & $99.69 \%$ \\
\hline C.111 & 0.00 & 216.00 & $2.34 E+08$ & $99.71 \%$ \\
\hline BY-112 & 30.00 & 1070.00 & $2.18 E+08$ & $99.72 \%$ \\
\hline$\overline{A X-101}$ & 1210.00 & 1620.00 & $2.17 E+08$ & $99.74 \%$ \\
\hline$\overline{T X-108}$ & 0.00 & 507.00 & $1.93 E+08$ & $99.75 \%$ \\
\hline $8-108$ & 15.00 & 341.00 & $1.87 E+08$ & $99.77 \%$ \\
\hline $8 x-103$ & 15.00 & 235.00 & $1.58 E+08$ & $99.78 \%$ \\
\hline U-106 & 314.00 & 541.00 & 1.51E+08 & $99.79 \%$ \\
\hline TY-104 & 57.00 & 117.00 & $1.43 E+08$ & $99.80 \%$ \\
\hline TY.101 & 0.00 & 447.00 & $1.42 E+08$ & $99.81 \%$ \\
\hline$T X-103$ & 57.00 & 538.00 & $1.41 E+08$ & $99.82 \%$ \\
\hline$T-101$ & 64.00 & 322.00 & $1.31 E+08$ & $99.83 \%$ \\
\hline $8 X-108$ & 3.79 & 95.00 & $1.24 E+08$ & $99.84 \%$ \\
\hline A-104 & 0.00 & 106.00 & $1.14 E+08$ & $99.85 \%$ \\
\hline BX-105 & 42.00 & 151.00 & $1.10 E+08$ & $99.86 \%$ \\
\hline$T-108$ & 0.00 & 167.00 & $1.10 E+08$ & $99.86 \%$ \\
\hline A-106 & 26.00 & 447.00 & $1.09 E+08$ & $99.87 \%$ \\
\hline A-103 & 76.00 & 1330.00 & $1.03 E+08$ & $99.88 \%$ \\
\hline$\overline{B X-102}$ & 15.00 & 348.00 & $1.02 E+08$ & $99.89 \%$ \\
\hline$T X-102$ & 83.00 & 738.00 & 1.01E+08 & $99.90 \%$ \\
\hline$\overline{B X}-104$ & 125.00 & 250.00 & $9.84 E+07$ & $99.90 \%$ \\
\hline S-103 & 386.00 & 553.00 & $9.82 E+07$ & $99.91 \%$ \\
\hline U-104 & 26.00 & 435.00 & $9.59 E+07$ & $99.92 \%$ \\
\hline $\mathrm{T}-106$ & 7.57 & 71.90 & $8.84 E+07$ & $99.92 \%$ \\
\hline B-109 & 30.00 & 450.00 & $8.38 E+07$ & $99.93 \%$ \\
\hline$\overline{T x-104}$ & 57.00 & 189.00 & 8.31E+07 & $99.94 \%$ \\
\hline $\mathrm{B}-112$ & 11.00 & 114.00 & $7.87 E+07$ & $99.94 \%$ \\
\hline$\overline{B X-106}$ & 57.00 & 117.00 & $7.44 E+07$ & $99.95 \%$ \\
\hline$B X-101$ & 4.00 & 159.00 & $6.95 E+07$ & $99.95 \%$ \\
\hline$T-103$ & 15.00 & 87.00 & $6.82 E+07$ & $99.96 \%$ \\
\hline$T-102$ & 49.00 & 72.00 & $6.55 E+07$ & $99.96 \%$ \\
\hline$T Y \cdot 106$ & 0.00 & 64.00 & $5.32 \mathrm{E}+07$ & $99.97 \%$ \\
\hline $\mathrm{U}-101$ & 11.00 & 83.00 & $5.26 E+07$ & $99.97 \%$ \\
\hline B-106 & 26.00 & 416.00 & $5.14 E+07$ & $99.97 \%$ \\
\hline B-101 & 23.00 & 405.00 & $4.45 E+07$ & $99.98 \%$ \\
\hline$T Y \cdot 102$ & 53.00 & 189.00 & 4.35E+07 & $99.98 \%$ \\
\hline$T X-107$ & 7.57 & 129.00 & $3.69 E+07$ & $99.98 \%$ \\
\hline B-103 & 0.00 & 223.00 & $3.20 E+07$ & $99.99 \%$ \\
\hline$A X-103$ & 136.00 & 288.00 & $2.96 E+07$ & $99.99 \%$ \\
\hline
\end{tabular}


WHC-SD-WM-TI-711

Revision 0

APPENDIX F.1

RANKING OF SINGLE-SHELL. TANKS BY INSOLUBLE CHEMICAL HAZARD

\begin{tabular}{|l|c|c|c|c|}
\hline TANK & LIQUID & SOLID & INSOLUELE & CUMULATIVE \\
\hline & $(\mathrm{m} 3)$ & $(\mathrm{m} 3)$ & HAZ. INDEX & $\%$ \\
\hline & & & H(insol) & \\
\hline T-109 & 0.00 & 220.00 & $2.61 E+07$ & $99.99 \%$ \\
\hline B-102 & 15.00 & 106.00 & $2.14 E+07$ & $99.99 \%$ \\
\hline AX-102 & 64.00 & 83.00 & $1.65 E+07$ & $99.99 \%$ \\
\hline$U-202$ & 3.79 & 189.00 & $1.53 E+07$ & $99.99 \%$ \\
\hline$U-201$ & 3.79 & 189.00 & $1.53 E+07$ & $100.00 \%$ \\
\hline C-203 & 0.00 & 19.00 & $1.20 E+07$ & $100.00 \%$ \\
\hline A-102 & 22.00 & 132.00 & $1.05 E+07$ & $100.00 \%$ \\
\hline$U-203$ & 3.79 & 114.00 & $7.64 E+06$ & $100.00 \%$ \\
\hline$U-204$ & 3.79 & 114.00 & $7.64 E+06$ & $100.00 \%$ \\
\hline C-204 & 0.00 & 11.00 & $7.19 E+06$ & $100.00 \%$ \\
\hline$A-105$ & 15.00 & 57.00 & $7.07 E+06$ & $100.00 \%$ \\
\hline C-201 & 0.00 & 7.57 & $4.79 E+06$ & $100.00 \%$ \\
\hline AX-104 & 0.00 & 26.00 & $2.61 E+06$ & $100.00 \%$ \\
\hline C-202 & 0.00 & 3.77 & $2.40 E+06$ & $100.00 \%$ \\
\hline TOTAL: & & & $1.35 E+121$ & \\
\hline
\end{tabular}


WHC-SD-WM-TI-711

Revision 0

APPENDIX F.2

RANKING OF SINGLE-SHELL TANKS BY SOLUBLE CHEMICAL HAZARDS

\begin{tabular}{|c|c|c|c|c|}
\hline TANK & LIQUID & SOLID & SOLUELE & CUMULATIVE \\
\hline & $(\mathrm{m} 3)$ & $(m 3)$ & HAZ. INDEX & $\%$ \\
\hline & & & $H(s o l)$ & \\
\hline $5 x-102$ & 693.00 & 1360.00 & $2.84 E+11$ & $3.57 \%$ \\
\hline$T x-112$ & 91.00 & 2370.00 & $2.63 E+11$ & $6.88 \%$ \\
\hline$T x-115$ & 72.00 & 2350.00 & $2.63 E+11$ & $10.18 \%$ \\
\hline$T X-105$ & 76.00 & 2230.00 & 2.51E+11 & $13.34 \%$ \\
\hline$T x-114$ & 57.00 & 1970.00 & $2.02 E+11$ & $15.88 \%$ \\
\hline Sx-105 & 988.00 & 1600.00 & $1.95 E+11$ & $18.33 \%$ \\
\hline$T X-117$ & 30.00 & 2340.00 & $1.93 E+11$ & $20.76 \%$ \\
\hline$T X-106$ & 38.00 & 1680.00 & $1.88 E+11$ & $23.13 \%$ \\
\hline$T x-113$ & 61.00 & 2240.00 & $1.805+11$ & $25.39 \%$ \\
\hline$\overline{T X-110}$ & 57.00 & 1690.00 & $1.78 E+11$ & $27.63 \%$ \\
\hline $5 x-103$ & 882.00 & 1590.00 & $1.66 E+11$ & $29.71 \%$ \\
\hline BY-106 & 890.00 & 1450.00 & $1.64 E+11$ & $31.77 \%$ \\
\hline$\overline{S x-114}$ & 53.00 & 632.00 & $1.61 E+11$ & $33.79 \%$ \\
\hline sx-109 & 38.00 & 908.00 & $1.61 E+11$ & $35.81 \%$ \\
\hline$\overline{5 x-104}$ & 761.00 & 1560.00 & $1.53 E+11$ & $37.74 \%$ \\
\hline S-112 & 416.00 & 1560.00 & $1.51 E+11$ & $39.64 \%$ \\
\hline A-101 & 1560.00 & 2040.00 & $1.50 E+11$ & $41.52 \%$ \\
\hline$T X-116$ & 87.00 & 2300.00 & $1.49 E+11$ & $43.39 \%$ \\
\hline S-109 & 534.00 & 1620.00 & 1.45E+11 & $45.22 \%$ \\
\hline S-108 & 481.00 & 1810.00 & $1.38 E+11$ & $46.95 \%$ \\
\hline$\overline{T X-111}$ & 34.00 & 1370.00 & $1.37 \mathrm{E}+11$ & $48.67 \%$ \\
\hline S-106 & 719.00 & 1090.00 & $1.34 E+11$ & $50.35 \%$ \\
\hline$\overline{T X-118}$ & 103.00 & 1210.00 & $1.30 E+11$ & $51.99 \%$ \\
\hline BY-111 & 0.00 & 1740.00 & $1.28 E+11$ & $53.60 \%$ \\
\hline S-111 & 776.00 & 1480.00 & $1.24 E+11$ & $55.16 \%$ \\
\hline S-105 & 132.00 & 1590.00 & $1.19 E+11$ & $56.66 \%$ \\
\hline$\overline{B Y-103}$ & 606.00 & 908.00 & $1.16 E+11$ & $58.12 \%$ \\
\hline BY-109 & 269.00 & 1330.00 & $1.15 E+11$ & $59.56 \%$ \\
\hline AX-101 & 1210.00 & 1620.00 & $1.13 E+11$ & $60.98 \%$ \\
\hline $\mathrm{U}-102$ & 545.00 & 871.00 & $1.08 E+11$ & $62.34 \%$ \\
\hline S-102 & 871.00 & 1210.00 & $1.06 E+11$ & $63.68 \%$ \\
\hline BY-105 & 727.00 & 1180.00 & $1.04 E+11$ & $64.98 \%$ \\
\hline BY-101 & 19.00 & 1450.00 & $1.04 E+11$ & $66.29 \%$ \\
\hline U-103 & 715.00 & 1060.00 & $1.03 E+11$ & $67.58 \%$ \\
\hline $5 x-111$ & 26.00 & 447.00 & $1.02 E+11$ & $68.86 \%$ \\
\hline $5 x-101$ & 552.00 & 1170.00 & $1.02 E+11$ & $70.14 \%$ \\
\hline S-107 & 223.00 & 1200.00 & $9.97 E+10$ & $71.39 \%$ \\
\hline $\mathrm{U}-108$ & 742.00 & 1030.00 & $9.72 E+10$ & $72.62 \%$ \\
\hline$S-110$ & 416.00 & 1060.00 & $9.70 E+10$ & $73.83 \%$ \\
\hline 5X-106 & 965.00 & 1070.00 & $9.50 \mathrm{E}+10$ & $75.03 \%$ \\
\hline U.109 & 689.00 & 1060.00 & $9.25 \mathrm{E}+10$ & $76.19 \%$ \\
\hline BY-102 & 110.00 & 1180.00 & $9.24 \mathrm{E}+10 \mathrm{I}$ & $77.35 \%$ \\
\hline S-104 & 110.00 & 1000.00 & $8.93 E+10$ & $78.48 \%$ \\
\hline S-101 & 363.00 & 1250.00 & $8.92 E+101$ & $79.60 \%$ \\
\hline $\mathrm{U}-105$ & 678.00 & 905.00 & $8.53 \mathrm{E}+10 \mathrm{I}$ & $80.67 \%$ \\
\hline
\end{tabular}

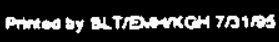


WHC-SD-WM-TI-711

Revision 0

APPENDIX F.2

RANKING OF SINGLE-SHELL TANKS BY SOLUBLE CHEMICAL HAZARDS

\begin{tabular}{|c|c|c|c|c|}
\hline TANK & LIOUID & SOLID & SOLUELE & CUMULATIVE \\
\hline & $(\mathrm{m} 3)$ & (m) & HAZ. INDEX & $\%$ \\
\hline & & & $\mathrm{H}(\mathrm{sol})$ & \\
\hline BY-112 & 30.00 & 1070.00 & 8.17E+10! & $81.70 \%$ \\
\hline EY-104 & 68.00 & 1470.00 & $8.01 E+10 i$ & $82.70 \%$ \\
\hline $5 x-110$ & 0.00 & 235.00 & $7.11 E+10$ & $83.60 \%$ \\
\hline $\mathrm{U}-111$ & 462.00 & 784.00 & $7.00 E+101$ & $84.48 \%$ \\
\hline BY-110 & 34.00 & 1470.00 & $6.72 E+10 \mid$ & $85.32 \%$ \\
\hline$T X-103$ & 57.00 & 538.00 & $6.45 E+10$ & $86.13 \%$ \\
\hline U-107 & 674.00 & 863.00 & $6.33 E+10$ & $86.93 \%$ \\
\hline $5 x-112$ & 11.00 & 337.00 & $6.25 E+101$ & $87.72 \%$ \\
\hline $5 X-108$ & 19.00 & 310.00 & $6.09 E+10 i$ & $88.48 \%$ \\
\hline $5 x-107$ & 19.00 & 375.00 & $5.87 E+10$ & $89.22 \%$ \\
\hline$B X-111$ & 95.00 & 704.00 & $5.38 E+101$ & $89.90 \%$ \\
\hline S-103 & 386.00 & 553.00 & $5.35 E+10$ & $90.57 \%$ \\
\hline$T x-108$ & 0.00 & 507.00 & $5.33 E+101$ & $91.24 \%$ \\
\hline A-103 & 76.00 & 1330.00 & $5.29 E+101$ & $91.90 \%$ \\
\hline $0-106$ & 314.00 & 541.00 & $4.85 E+101$ & $92.51 \%$ \\
\hline BY-107 & 95.00 & 912.00 & $4.77 E+10 \mid$ & $93.11 \%$ \\
\hline$T x-102$ & 83.00 & 738.00 & $4.58 E+101$ & $93.69 \%$ \\
\hline B-105 & 87.00 & 1070.00 & $2.53 E+10$ & $94.01 \%$ \\
\hline$\overline{T Y}-103$ & 19.00 & 594.00 & $2.51 E+101$ & $94.32 \%$ \\
\hline BX-109 & 49.00 & 681.00 & $2.42 E+101$ & $94.63 \%$ \\
\hline C-109 & 15.00 & 235.00 & $2.40 E+101$ & $94.93 \%$ \\
\hline BY-108 & 34.00 & 839.00 & $2.38 E+101$ & $95.23 \%$ \\
\hline $5 x-115$ & 0.00 & 45.00 & $2.20 E+101$ & $95.50 \%$ \\
\hline$T x-104$ & 57.00 & 189.00 & $1.92 E+101$ & $95.75 \%$ \\
\hline$T X-101$ & 19.00 & 310.00 & $1.84 E+101$ & $95.98 \%$ \\
\hline$T Y=102$ & 53.00 & 189.00 & $1.72 E+10 !$ & $96.19 \%$ \\
\hline$B X-110$ & 72.00 & 712.00 & $1.54 \mathrm{E}+101$ & $96.39 \%$ \\
\hline$\overline{A x-103}$ & 136.00 & 288.00 & $1.42 E+10 !$ & $96.57 \%$ \\
\hline C-104 & 42.00 & 1070.00 & $1.37 E+101$ & $96.74 \%$ \\
\hline$T-111$ & 189.00 & 1530.00 & $1.31 E+101$ & $96.90 \%$ \\
\hline $\mathrm{C}-112$ & 121.00 & 272.00 & $1.21 E+101$ & $97.05 \%$ \\
\hline A-106 & 26.00 & 447.00 & $1.205+101$ & $97.21 \%$ \\
\hline$T x-107$ & 7.57 & 129.00 & $1.13 E+101$ & $97.35 \%$ \\
\hline$T-110$ & 159.00 & 1280.00 & $1.09 E+10$ & $97.48 \%$ \\
\hline$c-102$ & 113.00 & 1480.00 & $1.08 E+101$ & $97.62 \%$ \\
\hline B-104 & 178.00 & 1230.00 & $1.03 E+101$ & $97.75 \%$ \\
\hline $3-106$ & 26.00 & 416.00 & $1.03 E+101$ & $97.88 \%$ \\
\hline$T-104$ & 189.00 & 1490.00 & $8.34 E+091$ & $97.98 \%$ \\
\hline B-109 & 30.00 & 450.00 & $7.60 E+091$ & $98.08 \%$ \\
\hline$\overline{T X-109}$ & 38.00 & 1420.00 & $7.28 E+09 !$ & $98.17 \%$ \\
\hline B-101 & 23.00 & 405.00 & $7.08 E+091$ & $98.26 \%$ \\
\hline $8-110$ & 87.00 & 844.00 & $6.68 E+091$ & $98.34 \%$ \\
\hline$B X-107$ & 114.00 & 1190.00 & $6.51 E+091$ & $98.43 \%$ \\
\hline $\mathrm{B}-111$ & 83.00 & 813.00 & 6.15E+091 & $98.50 \%$ \\
\hline B-108 & 15.00 & 341.00 & $5.96 E+09 !$ & $98.58 \%$ \\
\hline
\end{tabular}

$\mathrm{F}-12$ 
WHC-SD-WM-TI-711

Revision 0

APPENDIX $F .2$

RANKING OF SINGLE-SHELL TANKS BY SOLUBLE CHEMICAL HAZARDS

\begin{tabular}{|c|c|c|c|c|}
\hline TANK & LIQUID & SOLID & SOLUBLE & CUMULATIVE \\
\hline & $(\mathrm{m} 3)$ & $(m 3)$ & HAZ. INDEX & $\%$ \\
\hline & & & $\mathrm{H}(\mathrm{sol})$ & \\
\hline TY-101 & 0.00 & 447.00 & $5.45 E+09 i$ & $98.65 \%$ \\
\hline A-102 & 22.00 & 132.00 & $5.37 E+09 !$ & $98.71 \%$ \\
\hline$B X-112$ & 30.00 & 594.00 & $5.33 E+091$ & $98.78 \%$ \\
\hline$T-109$ & 0.00 & 220.00 & $5.18 E+09$ & $98.85 \%$ \\
\hline$B-112$ & 11.00 & 114.00 & $5.12 \xi+091$ & $98.91 \%$ \\
\hline B-103 & 0.00 & 223.00 & 4.97E+09! & $98.97 \%$ \\
\hline $\mathrm{B}-203$ & 23.00 & 170.00 & $4.943+091$ & $99.04 \%$ \\
\hline B-204 & 23.00 & 167.00 & $4.84 E+09 !$ & $99.10 \%$ \\
\hline C-107 & 95.00 & 945.00 & $4.74 \mathrm{E}+091$ & $99.16 \%$ \\
\hline$A x-102$ & 64.00 & 83.00 & $4.50 E+091$ & $99.21 \%$ \\
\hline$T Y-105$ & 0.00 & 874.00 & $4.48 E+091$ & $99.27 \%$ \\
\hline$T-204$ & 15.00 & 129.00 & $3.74 E+09 !$ & $99.32 \%$ \\
\hline C.110 & 15.00 & 692.00 & $3.54 E+09$ & $99.36 \%$ \\
\hline$T-203$ & 15.00 & 117.00 & $3.45 E+09 !$ & $99.40 \%$ \\
\hline U-110 & 57.00 & 647.00 & $3.37 E+09$ & $99.45 \%$ \\
\hline B-107 & 49.00 & 575.00 & $3.11 E+09 !$ & $99.49 \%$ \\
\hline B-201 & 15.00 & 95.00 & $2.76 E+09 i$ & $99.52 \%$ \\
\hline$T-201$ & 15.00 & 95.00 & $2.76 E+091$ & $99.55 \%$ \\
\hline B-202 & 11.00 & 91.00 & $2.67 E+091$ & $99.59 \%$ \\
\hline T-107 & 83.00 & 598.00 & $2.48 E+09 \mid$ & $99.62 \%$ \\
\hline$T-108$ & 0.00 & 167.00 & $2.44 E+09 !$ & $99.65 \%$ \\
\hline$T-105$ & 87.00 & 284.00 & $2.42 E+091$ & $99.68 \%$ \\
\hline $\mathrm{C}-106$ & 182.00 & 685.00 & $2.36 E+091$ & $99.71 \%$ \\
\hline$T-103$ & 15.00 & 87.00 & $2.28 E+091$ & $99.74 \%$ \\
\hline $\mathrm{U}-112$ & 15.00 & 170.00 & $2.25 E+091$ & $99.77 \%$ \\
\hline$c-105$ & 53.00 & 458.00 & $2.24 E+091$ & $99.80 \%$ \\
\hline 8-102 & 15.00 & 106.00 & $2.15 E+09$ & $99.82 \%$ \\
\hline$T-202$ & 7.57 & 719.00 & $2.08 E+09$ & $99.85 \%$ \\
\hline C-101 & 11.00 & 320.00 & $1.89 E+091$ & $99.87 \%$ \\
\hline C-108 & 0.00 & 250.00 & $1.70 E+09$ & $99.89 \%$ \\
\hline TY-104 & 57.00 & 117.00 & $1.22 E+091$ & $99.91 \%$ \\
\hline$T-112$ & 26.00 & 227.00 & $1.22 E+091$ & $99.92 \%$ \\
\hline C-111 & 0.00 & 216.00 & $1.065+09 \mid$ & $99.94 \%$ \\
\hline C-103 & 503.00 & 235.00 & $5.57 E+08 i$ & $99.94 \%$ \\
\hline$B X-108$ & 3.79 & 95.00 & $4.94 E+081$ & $99.95 \%$ \\
\hline$T-101$ & 64.00 & 322.00 & $4.70 E+08$ & $99.96 \%$ \\
\hline$T Y-106$ & 0.00 & 64.00 & 4.53E+08 & $99.96 \%$ \\
\hline $5 x-113$ & 0.00 & 98.00 & $4.26 E+08 !$ & $99.97 \%$ \\
\hline$T-106$ & 7.57 & 71.90 & $3.50 E+08$ & $99.97 \%$ \\
\hline A-104 & 0.00 & 106.00 & $2.84 E+081$ & $99.98 \%$ \\
\hline BX-103 & 15.00 & 235.00 & $2.75 E+08 !$ & $99.98 \%$ \\
\hline BX-101 & 4.00 & 159.00 & $2.73 E+081$ & $99.98 \%$ \\
\hline$T-102$ & 49.00 & 72.00 & $1.98 E+081$ & $99.98 \%$ \\
\hline$B X-102$ & 15.00 & 348.00 & $1.75 E+081$ & $99.99 \%$ \\
\hline$B X-105$ & 42.00 & 151.00 & $1.57 E+081$ & $99.99 \%$ \\
\hline
\end{tabular}


WHC-SD-WM-TI-711

Revision 0

APPENDIX F.2

RANKING OF SINGLE-SHELL TANKS BY SOLUBLE CHEMICAL HAZARDS

\begin{tabular}{|l|c|c|c|c|}
\hline TANK & LIQUDD & SOLID & SOLUELE & CUMULATIVE \\
\hline & $(\mathrm{m} 3)$ & $(\mathrm{m} 3)$ & HAZ. INDEX & $\%$ \\
\hline & & & H(sol $)$ & \\
\hline BX-104 & 125.00 & 250.00 & $1.40 E+08$ & $99.99 \%$ \\
\hline$U-104$ & 26.00 & 435.00 & $1.36 E+08$ & $99.99 \%$ \\
\hline$U-201$ & 3.79 & 189.00 & $1.14 E+08$ & $99.99 \%$ \\
\hline$U-202$ & 3.79 & 189.00 & $1.14 E+08$ & $100.00 \%$ \\
\hline$B X-106$ & 57.00 & 117.00 & $1.06 E+08$ & $100.00 \%$ \\
\hline$U-101$ & 11.00 & 83.00 & $7.46 E+07$ & $100.00 \%$ \\
\hline$U-203$ & 3.79 & 114.00 & $7.08 E+07$ & $100.00 \%$ \\
\hline$U-204$ & 3.79 & 114.00 & $4.58 E+07$ & $100.00 \%$ \\
\hline$A-105$ & 15.00 & 57.00 & $1.87 E+07$ & $100.00 \%$ \\
\hline$C-203$ & 0.00 & 19.00 & $1.71 E+07$ & $100.00 \%$ \\
\hline$C-204$ & 0.00 & 11.00 & $1.02 E+07$ & $100.00 \%$ \\
\hline$A X-104$ & 0.00 & 26.00 & $6.93 E+06$ & $100.00 \%$ \\
\hline C-201 & 0.00 & 7.57 & $6.81 E+06$ & $100.00 \%$ \\
\hline C-202 & 0.00 & 3.77 & $3.42 E+06$ & $100.00 \%$ \\
\hline TOTALS: & & & $7.95 E+12$ & \\
\hline
\end{tabular}


WHC-SD-WM-TI-711

Revision 0

\author{
APPENDIX G \\ RANKING OF SINGLE-SHELL TANKS \\ BY MOBILE ALIs; \\ CUMULATIVE PERCENT OF MOBILE ALIs
}

G-1 
WHC-SD-WM-TI-711

Revision 0

This page intentionally left blank. 
WHC-SD-WM-TI-711

Revision 0

APPENDIX G

RANKING OF SINGLE-SHELL TANKS BY MOBILE ALI'S ; CUMULATIVE PERCENT OF MOBILE ALI'S

\begin{tabular}{|c|c|c|}
\hline TANK & MOBILE ALI's & \% MOBILE \\
\hline & (RELATIVE GROUNDWATER HAZARD) & \\
\hline $\mathrm{TX}-104$ & $1.06 E+07$ & $19.00 \%$ \\
\hline BY-108 & $5.12 E+06$ & $28.18 \%$ \\
\hline BY-104 & $4.14 E+06$ & $35.61 \%$ \\
\hline$T X-108$ & $2.17 E+06$ & $39.49 \%$ \\
\hline BY-109 & $1.98 E+06$ & $43.04 \%$ \\
\hline$\overline{T X-106}$ & $1.85 E+06$ & $46.35 \%$ \\
\hline C-109 & $1.65 E+06$ & $49.32 \%$ \\
\hline $\mathrm{C}-106$ & $1.59 \xi+06$ & $52.18 \%$ \\
\hline S-111 & $1.33 E+06$ & $54.57 \%$ \\
\hline$T X-109$ & $1.07 E+06$ & $56.49 \%$ \\
\hline C-108 & $9.71 E+05$ & $58.23 \%$ \\
\hline B-112 & $9.122+05$ & $59.87 \%$ \\
\hline B-202 & $8.02 E+05$ & $61.31 \%$ \\
\hline A-101 & $7.70 E+05$ & $62.69 \%$ \\
\hline B-105 & $7.64 E+05$ & $64.06 \%$ \\
\hline C-107 & $7.53 E+05$ & $65.41 \%$ \\
\hline $\mathrm{B}-111$ & $6.79 E+05$ & $66.63 \%$ \\
\hline BY-111 & $6.23 E+05$ & $67.75 \%$ \\
\hline$B X-108$ & $5.98 E+05$ & $68.82 \%$ \\
\hline$B X-105$ & $5.67 E+05$ & $69.84 \%$ \\
\hline BY-107 & $5.20 \bar{E}+05$ & $70.77 \%$ \\
\hline$T X-114$ & $5.18 E+05$ & $71.70 \%$ \\
\hline B-203 & 5.15E+05 & $72.63 \%$ \\
\hline BY-101 & $5.13 E+05$ & $73.55 \%$ \\
\hline BX-104 & $5.11 E+05$ & $74.46 \%$ \\
\hline$B X-106$ & $4.76 E+05$ & $75.32 \%$ \\
\hline$S-112$ & $4.39 E+05$ & $76.10 \%$ \\
\hline SX-104 & $4.35 E+05$ & $76.89 \%$ \\
\hline$B X-110$ & $4.27 E+05$ & $77.65 \%$ \\
\hline SX-103 & $4.04 E+05$ & $78.38 \%$ \\
\hline C-105 & $3.87 E+05$ & $79.07 \%$ \\
\hline A-106 & $3.82 E+05$ & $79.76 \%$ \\
\hline BX-102 & $3.78 z+05$ & $80.44 \%$ \\
\hline$T X-105$ & $3.77 \mathrm{E}+05$ & $81.11 \%$ \\
\hline C-111 & 3.73E+05 & $81.78 \%$ \\
\hline SX-107 & $3.42 E+05$ & $82.39 \%$ \\
\hline$T X-107$ & $3.18 E+05$ & $82.96 \%$ \\
\hline$T X-112$ & $3.05 E+05$ & $83.51 \%$ \\
\hline$U-103$ & $2.85 E+05$ & $84.02 \%$ \\
\hline C-110 & $2.78 E+05$ & $84.52 \%$ \\
\hline$T-204$ & $2.76 E+05$ & $85.02 \%$ \\
\hline S-105 & $2.74 E+05$ & $85.51 \%$ \\
\hline$s x-115$ & $2.63 E+05$ & $85.98 \%$ \\
\hline $\mathrm{TX}-116$ & $2.54 E+05$ & $86.44 \%$ \\
\hline $\mathrm{U}-112$ & $2.54 E+05$ & $86.89 \%$ \\
\hline $5 \times-105$ & $2.53 E+05$ & $87.35 \%$ \\
\hline
\end{tabular}




\section{WHC-SD-WM-TI-711}

Revision 0

APPENDIX G

RANKING OF SINGLESHELL TANKS BY MOBILE ALI'S ; CUMULATIVE PERCENT OF MOBILE ALI'S

\begin{tabular}{|c|c|c|}
\hline TANK & MOBILE ALP'S & \% MOBILE \\
\hline & (RELATIVE GROUNDWATER HAZARD) & \\
\hline BX-109 & $2.46 E+05$ & $87.79 \%$ \\
\hline S-108 & $2.34 E+05$ & $88.21 \%$ \\
\hline B-201 & $2.23 E+05$ & $88.61 \%$ \\
\hline T-103 & $2.20 E+05$ & $89.00 \%$ \\
\hline B-107 & $2.05 E+05$ & $89.37 \%$ \\
\hline A-104 & $1.92 E+05$ & $89.71 \%$ \\
\hline$S X-112$ & $1.86 E+05$ & $90.05 \%$ \\
\hline C-103 & $1.85 E+05$ & $90.38 \%$ \\
\hline SX-114 & $1.77 E+05$ & $90.70 \%$ \\
\hline SX-111 & $1.73 E+05$ & $91.01 \%$ \\
\hline$A-102$ & $1.73 E+05$ & $91.32 \%$ \\
\hline SX-108 & $1.68 E+05$ & $91.62 \%$ \\
\hline C-204 & $1.63 E+05$ & $91.91 \%$ \\
\hline A-103 & $1.61 E+05$ & $92.20 \%$ \\
\hline $\mathrm{C}-112$ & $1.55 E+05$ & $92.48 \%$ \\
\hline BY-110 & $1.52 E+05$ & $92.75 \%$ \\
\hline Sx-102 & $1.48 E+05$ & $93.02 \%$ \\
\hline $\bar{T}-118$ & $1.37 E+05$ & $93.26 \%$ \\
\hline BY-112 & $1.36 E+05$ & $93.51 \%$ \\
\hline$B X-111$ & $1.34 E+05$ & $93.75 \%$ \\
\hline $5 x-113$ & $1.335+05$ & $93.99 \%$ \\
\hline $\mathrm{U}-201$ & $1.32 E+05$ & $94.22 \%$ \\
\hline U-101 & $1.32 \sum+05$ & $94.46 \%$ \\
\hline BY-106 & $1.31 E+05$ & $94.69 \%$ \\
\hline BY-105 & $1.25 E+05$ & $94.92 \%$ \\
\hline$A x-101$ & $1.17 E+05$ & $95.13 \%$ \\
\hline SX-109 & $1.16 E+05$ & $95.33 \%$ \\
\hline U-104 & $1.10 \mathrm{E}+05$ & $95.53 \%$ \\
\hline C-203 & $1.09 E+05$ & $95.73 \%$ \\
\hline S-109 & $1.08 E+05$ & $95.92 \%$ \\
\hline$T Y \cdot 103$ & $1.08 E+05$ & $96.11 \%$ \\
\hline$U-111$ & $1.01 E+05$ & $96.30 \%$ \\
\hline$T Y-105$ & $9.77 E+04$ & $96.47 \%$ \\
\hline$T x-101$ & $9.69 E+04$ & $96.64 \%$ \\
\hline BY-102 & 9.47E+04 & $96.81 \%$ \\
\hline B-204 & $9.25 E+04$ & $96.98 \%$ \\
\hline sX-101 & $9.20 E+04$ & $97.15 \%$ \\
\hline U-107 & $8.37 E+04$ & $97.30 \%$ \\
\hline B-106 & $7.90 E+04$ & $97.44 \%$ \\
\hline$T X-110$ & $7.86 E+04$ & $97.58 \%$ \\
\hline$B-110$ & $7.52 E+04$ & $97.71 \%$ \\
\hline S-110 & $6.98 E+04$ & $97.84 \%$ \\
\hline$C-102$ & $6.64 E+04$ & $97.96 \%$ \\
\hline U-102 & $6.63 E+04$ & $98.08 \%$ \\
\hline$B Y-103$ & $6.51 \mathrm{E}+04$ & $98.19 \%$ \\
\hline$T-102$ & $6.43 E+04$ & $98.31 \%$ \\
\hline
\end{tabular}


WHC-SD-WM-TI-711

Revision 0

APPENDIX G

RANKING OF SINGLESHELL TANKS BY MOBILE ALI'S ; CUMULATIVE PERCENT OF MOBILE ALI'S

\begin{tabular}{|c|c|c|}
\hline TANK & MOBILEALI'S & $\%$ MOBILE \\
\hline & (RELATIVE GROUNDWATER HAZARD) & ALT's CUM. \\
\hline C-101 & $6.32 E+04$ & $98.42 \%$ \\
\hline $\mathbf{S X - 1 1 0}$ & $6.21 E+04$ & $98.53 \%$ \\
\hline$T X-115$ & $5.87 E+04$ & $98.64 \%$ \\
\hline SX-106 & $5.86 E+04$ & $98.74 \%$ \\
\hline$\overline{T X-111}$ & $4.71 E+04$ & $98.83 \%$ \\
\hline S-106 & $4.40 E+04$ & $98.91 \%$ \\
\hline TY.102 & $4.00 E+04$ & $98.98 \%$ \\
\hline B-108 & $3.83 E+04$ & $99.05 \%$ \\
\hline U-106 & $3.82 E+04$ & $99.12 \%$ \\
\hline$T-101$ & $3.61 E+04$ & $99.18 \%$ \\
\hline $\mathrm{U}-105$ & $3.47 E+04$ & $99.24 \%$ \\
\hline $\mathrm{U}-202$ & $3.33 E+04$ & $99.30 \%$ \\
\hline S-101 & $3.13 E+04$ & $99.36 \%$ \\
\hline$T X-102$ & $2.81 \mathrm{E}+04$ & $99.41 \%$ \\
\hline C-201 & $2.49 E+04$ & $99.46 \%$ \\
\hline $\mathrm{TX}-113$ & $2.42 E+04$ & $99.50 \%$ \\
\hline S-102 & $2.37 E+04$ & $99.54 \%$ \\
\hline B-109 & $2.35 E+04$ & $99.58 \%$ \\
\hline$A X-104$ & $2.26 E+04$ & $99.62 \%$ \\
\hline$T-203$ & $2.20 E+04$ & $99.66 \%$ \\
\hline C-104 & $1.79 E+04$ & $99.70 \%$ \\
\hline U-108 & $1.693+04$ & $99.73 \%$ \\
\hline B-101 & $1.62 E+04$ & $99.75 \%$ \\
\hline$T-112$ & $1.52 E+04$ & $99.78 \%$ \\
\hline$B X-112$ & $1.48 E+04$ & $99.81 \%$ \\
\hline$T Y-104$ & $1.44 E+04$ & $99.83 \%$ \\
\hline U-203 & $1.40 E+04$ & $99.86 \%$ \\
\hline C-202 & $1.33 E+04$ & $99.88 \%$ \\
\hline$T X-103$ & $7.921+03$ & $99.90 \%$ \\
\hline$\overline{T x-117}$ & $7.58 E+03$ & $99.91 \%$ \\
\hline BX-107 & $5.23 E+03$ & $99.92 \%$ \\
\hline U-204 & $4.63 E+03$ & $99.93 \%$ \\
\hline$A x-102$ & $4.01 E+03$ & $99.94 \%$ \\
\hline $\mathrm{B}-103$ & $3.99 E+03$ & $99.94 \%$ \\
\hline$A x-103$ & $3.95 E+03$ & $99.95 \%$ \\
\hline U.110 & $3.16 E+03$ & $99.96 \%$ \\
\hline$T Y-106$ & $3.11 \mathrm{E}+03$ & $99.96 \%$ \\
\hline$A-105$ & $3.10 E+03$ & $99.97 \%$ \\
\hline S-107 & $2.66 E+03$ & $99.97 \%$ \\
\hline $\mathrm{B}-104$ & $2.61 E+03$ & $99.98 \%$ \\
\hline $\mathrm{B}-102$ & $2.54 E+03$ & $99.98 \%$ \\
\hline $5-103$ & $2.37 E+03$ & $99.99 \%$ \\
\hline$T-109$ & 1.97E+03 & $99.99 \%$ \\
\hline U-109 & $1.65 E+03$ & $99.99 \%$ \\
\hline S-104 & $1.61 E+03$ & $100.00 \%$ \\
\hline$T-201$ & $1.48 \mathrm{E}+03$ & $100.00 \%$ \\
\hline
\end{tabular}


WHC-SD-WM-TI-711

Revision 0

APPENDIX G

RANKING OF SINGLESHELL TANKS BY MOBILE ALI'S ; CUMULATIVE PERCENT OF MOBILE ALI'S

\begin{tabular}{|l|c|c|}
\hline TANK & MOEILE ALI'S & \% MOBILE \\
\hline & (RELATIVE GROUNDWATER HAZARD) & ALI's CUM. \\
\hline$T-104$ & $5.41 E+02$ & $100.00 \%$ \\
\hline$T Y-101$ & $3.29 E+02$ & $100.00 \%$ \\
\hline$T-110$ & $2.36 E+02$ & $100.00 \%$ \\
\hline$T-108$ & $5.12 E+01$ & $100.00 \%$ \\
\hline$T-106$ & $2.83 E+01$ & $100.00 \%$ \\
\hline$T-111$ & $1.63 E+01$ & $100.00 \%$ \\
\hline$B X-103$ & $4.80 E-02$ & $100.00 \%$ \\
\hline$T-105$ & $2.06 E-02$ & $100.00 \%$ \\
\hline$T-202$ & $1.72 E-02$ & $100.00 \%$ \\
\hline$T-107$ & $2.63 E-14$ & $100.00 \%$ \\
\hline BX-101 & $9.40 E-15$ & $100.00 \%$ \\
\hline$T O T A L S:$ & $5.57 E+07$ & \\
\hline
\end{tabular}


WHC-SD-WM-TI-711

Revision 0

APPENDIX H

RANKING OF SINGLE-SHELL TANKS BY ${ }^{126}$ Sn CURIES;

CUMULATIVE PERCENT OF ${ }^{126}$ Sn CURIES

$\mathrm{H}-1$ 
WHC-SD-WM-TI-711

Revision 0

This page intentionally left blank.

H-2 
WHC-SD-WM-TI-711

Revision 0

APPENDIXH

RANKING OF SINGLE-SHELL TANKS BY Sn-126 CURIES ; CUMULATIVE PERCENT OF Sn-126 CURIES

\begin{tabular}{|c|c|c|}
\hline TANK & $\begin{array}{c}\text { Sn-126 CURIES } \\
\text { (RELATVE CAMMA HAZARD) }\end{array}$ & $\frac{\% \operatorname{sn}-126}{\text { Ci CUM. }}$ \\
\hline & & \\
\hline A-102 & $1.04 E+02$ & $17.50 \%$ \\
\hline C-105 & $6.03 E+01$ & $27.66 \%$ \\
\hline$\overline{A X-104}$ & $5.76 E+01$ & $37.37 \%$ \\
\hline$T X-118$ & $4.66 E+01$ & $45.22 \%$ \\
\hline$\overline{A-101}$ & $3.08 E+01$ & $50.41 \%$ \\
\hline A-104 & $2.51 E+01$ & $54.63 \%$ \\
\hline$\overline{S X-114}$ & $2.17 E+01$ & $58.29 \%$ \\
\hline$S x-111$ & $1.69 E+01$ & $61.14 \%$ \\
\hline $5 x-110$ & $1.63 E+01$ & $63.89 \%$ \\
\hline$A X-102$ & $1.45 E+01$ & $66.34 \%$ \\
\hline $5 X-108$ & 1.37E+01 & $68.65 \%$ \\
\hline $5 x-107$ & $1.25 E+01$ & $70.76 \%$ \\
\hline C-102 & $1.11 E+01$ & $72.62 \%$ \\
\hline C-106 & $1.06 E+01$ & $74.41 \%$ \\
\hline B-110 & $1.00 E+01$ & $76.10 \%$ \\
\hline $5 x-106$ & $8.88 E+00$ & $77.60 \%$ \\
\hline$S x-112$ & $8.85 E+00$ & $79.09 \%$ \\
\hline SX-109 & $7.27 \mathrm{E}+00$ & $80.31 \%$ \\
\hline B-101 & 7.07E+00 & $81.50 \%$ \\
\hline S.107 & $6.70 E+00$ & $82.63 \%$ \\
\hline BX-106 & $6.06 E+00$ & $83.65 \%$ \\
\hline BY-104 & $6.00 E+00$ & $84.66 \%$ \\
\hline A-106 & $5.96 E+00$ & $85.67 \%$ \\
\hline$\overline{s x-101}$ & $5.66 E+00$ & $86.62 \%$ \\
\hline$S x-115$ & $5.53 E+00$ & $87.56 \%$ \\
\hline $5 x-104$ & $5.23 E+00$ & $88.44 \%$ \\
\hline SX-103 & $4.93 E+00$ & $89.27 \%$ \\
\hline S-101 & $4.66 \mathrm{E}+00$ & $90.05 \%$ \\
\hline BY-105 & $4.32 E+00$ & $90.78 \%$ \\
\hline S-104 & $4.09 E+00$ & $91.47 \%$ \\
\hline U-107 & $3.20 E+00$ & $92.01 \%$ \\
\hline C-104 & $3.17 E+00$ & $92.54 \%$ \\
\hline BX-109 & $3.12 E+00$ & $93.07 \%$ \\
\hline TY-105 & $2.88 E+00$ & $93.55 \%$ \\
\hline U-110 & $2.87 E+00$ & $94.03 \%$ \\
\hline$S-110$ & $2.71 E+00$ & $94.49 \%$ \\
\hline $5 X-113$ & $2.26 E+00$ & $94.87 \%$ \\
\hline C-107 & $2.25 E+00$ & $95.25 \%$ \\
\hline S-109 & $2.25 E+00$ & $95.63 \%$ \\
\hline$A X-103$ & $2.11 E+00$ & $95.98 \%$ \\
\hline$B Y-110$ & $1.96 E+00$ & $96.31 \%$ \\
\hline C-103 & $1.74 E+00$ & $96.61 \%$ \\
\hline BY-108 & $1.41 \mathrm{E}+00$ & $96.84 \%$ \\
\hline BY-106 & $1.38 \mathrm{E}+00$ & $97.08 \%$ \\
\hline S-112 & $1.24 E+00$ & $97.28 \%$ \\
\hline BY-107 & 1.16E+00 & $97.48 \%$ \\
\hline
\end{tabular}


WHC-SD-WM-TI-711

Revision 0

APPENDIX H

RANKING OF SINGLE-SHELL TANKS BY Sn-126 CURIES ;

CUMULATIVE PERCENT OF $\mathbf{S n - 1 2 6}$ CURIES

\begin{tabular}{|c|c|c|}
\hline TANK & $\begin{array}{l}\text { Sn-126 CURाES } \\
\text { (REI ATIV }\end{array}$ & $\%$ Sn-126 \\
\hline & (RELAIVE GAMUMA FAVARD) & \\
\hline TY.103 & 1.11E+00 & $97.67 \%$ \\
\hline C-101 & $1.11 \mathrm{E}+00$ & $97.85 \%$ \\
\hline $\mathrm{U}-111$ & $1.06 E+00$ & $98.03 \%$ \\
\hline C-108 & 8.71E-01 & $98.18 \%$ \\
\hline SX-105 & 7.37E-01 & $98.30 \%$ \\
\hline S-108 & 7.14E-01 & $98.42 \%$ \\
\hline A-103 & 6.74E-01 & $98.54 \%$ \\
\hline 3-103 & $6.43 E-01$ & $98.65 \%$ \\
\hline C-112 & $6.06 E-01$ & $98.75 \%$ \\
\hline C-111 & 5.80E-01 & $98.85 \%$ \\
\hline SX-102 & 5.63E-01 & $98.94 \%$ \\
\hline BY-103 & $5.26 \mathrm{E}-01$ & $99.03 \%$ \\
\hline TX-109 & 4.99E-01 & $99.11 \%$ \\
\hline $\mathbf{S - 1 0 2}$ & 4.42E-01 & $99.19 \%$ \\
\hline S-111 & 4.09E-01 & $99.26 \%$ \\
\hline S-105 & 3.99E-01 & $99.32 \%$ \\
\hline$T-104$ & 3.59E-01 & $99.39 \%$ \\
\hline TY-101 & $3.59 E-01$ & $99.45 \%$ \\
\hline BX-107 & 3.25E-01 & $99.50 \%$ \\
\hline TY-106 & $3.20 E-01$ & $99.55 \%$ \\
\hline T-107 & 2.94E-01 & $99.60 \%$ \\
\hline $\mathrm{U}-101$ & 2.53E-01 & $99.65 \%$ \\
\hline $\mathrm{TX}-113$ & 1.81E-01 & $99.68 \%$ \\
\hline $\mathrm{B}-102$ & 1.77E-01 & $99.71 \%$ \\
\hline$T-105$ & $1.73 E-01$ & $99.74 \%$ \\
\hline U.102 & 1.65E-01 & $99.76 \%$ \\
\hline BX-104 & 1.54E-01 & $99.79 \%$ \\
\hline BX-101 & 1.29E-01 & $99.81 \%$ \\
\hline $\mathrm{C}-110$ & $1.14 \mathrm{E}-01$ & $99.83 \%$ \\
\hline TY-104 & $1.06 E-01$ & $99.85 \%$ \\
\hline U-108 & 1.05E-01 & $99.87 \%$ \\
\hline BX-110 & 6.80E-02 & $99.88 \%$ \\
\hline B-107 & $6.03 E-02$ & $99.89 \%$ \\
\hline B-104 & $5.96 E-02$ & $99.90 \%$ \\
\hline$B X-112$ & $5.73 E-02$ & $99.91 \%$ \\
\hline$T-112$ & $5.39 E-02$ & $99.92 \%$ \\
\hline S-106 & 5.03E-02 & $99.92 \%$ \\
\hline 5-103 & $4.93 E-02$ & $99.93 \%$ \\
\hline$T X-110$ & 4.19E-02 & $99.94 \%$ \\
\hline$T-110$ & 4.12E-02 & $99.95 \%$ \\
\hline$T-111$ & $3.92 E-02$ & $99.95 \%$ \\
\hline C-109 & $3.45 \mathrm{E}-02$ & $99.96 \%$ \\
\hline$B X-108$ & 3.25E-02 & $99.97 \%$ \\
\hline$T-108$ & 2.94E-02 & $99.97 \%$ \\
\hline TX-108 & 2.27E-02 & $99.97 \%$ \\
\hline $\mathrm{U}-112$ & $2.26 E-02$ & $99.98 \%$ \\
\hline
\end{tabular}

Printed by BL Trumpour 8710s 
WHC-SD-WM-TI-711

Revision 0

APPENDIX H

RANKING OF SINGLESHELL TANKS BY Sn-126 CURIES ; CUMULATIVE PERCENT OF Sn-126 CURIES

\begin{tabular}{|c|c|c|}
\hline TANK & Sn-126 CURा5s & $\% \operatorname{sn}-126$ \\
\hline & (RELATIVE GAMMA HAZARD) & Ci CUM. \\
\hline T-106 & 1.92E-02 & $99.98 \%$ \\
\hline$T X-114$ & 1.81E-02 & $99.98 \%$ \\
\hline B-111 & $1.38 E-02$ & $99.99 \%$ \\
\hline BY-111 & 1.23E-02 & 99.99\% \\
\hline $\mathrm{U}-109$ & 1.19E-02 & $99.99 \%$ \\
\hline $\mathrm{C}-202$ & 7.44E-03 & $99.99 \%$ \\
\hline $8 x-111$ & 6.80E-03 & $99.99 \%$ \\
\hline B-108 & 6.03E-03 & $99.99 \%$ \\
\hline U-105 & 6.00E-03 & $99.99 \%$ \\
\hline B-105 & $5.96 \mathrm{E}-03$ & $100.00 \%$ \\
\hline$T Y \cdot 102$ & 4.93E-03 & $100.00 \%$ \\
\hline$T X-111$ & $4.42 E-03$ & $100.00 \%$ \\
\hline$T-109$ & $3.27 E-03$ & $100.00 \%$ \\
\hline $\mathrm{C}-201$ & 2.70E-03 & $100.00 \%$ \\
\hline BY-101 & $2.09 E-03$ & $100.00 \%$ \\
\hline $\mathrm{TX}-115$ & $2.01 E-03$ & $100.00 \%$ \\
\hline $\mathrm{T}-103$ & 1.75E-03 & $100.00 \%$ \\
\hline B-112 & $1.42 \mathrm{E}-03$ & $100.00 \%$ \\
\hline B-109 & 7.77E-04 & $100.00 \%$ \\
\hline C-203 & 7.44E-04 & $100.00 \%$ \\
\hline B-106 & $6.63 E-04$ & $100.00 \%$ \\
\hline$T X-112$ & 2.25E-04 & $100.00 \%$ \\
\hline BY.102 & $2.09 E-04$ & $100.00 \%$ \\
\hline TX-104 & $1.20 E-05$ & $100.00 \%$ \\
\hline C-204 & $2.82 E-06$ & $100.00 \%$ \\
\hline A-105 & 1.08E-07 & $100.00 \%$ \\
\hline BX-105 & 8.78E-08 & $100.00 \%$ \\
\hline TX-107 & 4.99E-08 & $100.00 \%$ \\
\hline$T-101$ & 3.75E-08 & $100.00 \%$ \\
\hline$B X-103$ & $2.78 E-08$ & $100.00 \%$ \\
\hline U-106 & 2.71E-08 & $100.00 \%$ \\
\hline BY-109 & $1.65 \mathrm{E}-08$ & $100.00 \%$ \\
\hline U-104 & 1.25E-08 & $100.00 \%$ \\
\hline BY-112 & 1.05E-08 & $100.00 \%$ \\
\hline TX-101 & $6.43 E-09$ & $100.00 \%$ \\
\hline BX-102 & 4.72E-09 & $100.00 \%$ \\
\hline$T-102$ & 3.12E-09 & $100.00 \%$ \\
\hline$T X-103$ & $3.12 \mathrm{E}-09$ & $100.00 \%$ \\
\hline $\mathrm{TX}-106$ & $8.01 E-10$ & $100.00 \%$ \\
\hline TX-102 & $7.81 \mathrm{E}-10$ & $100.00 \%$ \\
\hline $\mathrm{U}-103$ & $7.81 E-10$ & $100.00 \%$ \\
\hline$\overline{T X-105}$ & $1.76 E-10$ & $100.00 \%$ \\
\hline $\mathrm{U}-201$ & $9.92 E-11$ & $100.00 \%$ \\
\hline$A x-101$ & $6.60 \mathrm{E}-11$ & $100.00 \%$ \\
\hline $\mathrm{U}-203$ & $4.96 E-11$ & $100.00 \%$ \\
\hline U-204 & $3.13 E-11$ & $100.00 \%$ \\
\hline
\end{tabular}


WHC-SD-WM-TI-711

Revision 0

APPENDIX H

RANKING OF SINGLE-SHELL TANKS BY Sn-126 CURIES ; CUMULATIVE PERCENT OF Sn-126 CURIES

\begin{tabular}{|l|c|c|}
\hline TANK & Sn-126 CURIBS & $\%$ Sn-126 \\
\hline & (RELATIVE GAMMA HAZARD) & Ci CUM. \\
\hline TX-117 & $1.66 E-12$ & $100.00 \%$ \\
\hline TX-116 & $8.48 E-13$ & $100.00 \%$ \\
\hline$U-202$ & $1.07 E-14$ & $100.00 \%$ \\
\hline B-201 & $0.00 E+00$ & $100.00 \%$ \\
\hline B-202 & $0.00 E+00$ & $100.00 \%$ \\
\hline B-203 & $0.00 E+00$ & $100.00 \%$ \\
\hline B-204 & $0.00 E+00$ & $100.00 \%$ \\
\hline T-201 & $0.00 E+00$ & $100.00 \%$ \\
\hline T-202 & $0.00 E+00$ & $100.00 \%$ \\
\hline T-203 & $0.00 E+00$ & $100.00 \%$ \\
\hline T-204 & $0.00 E+00$ & $100.00 \%$ \\
\hline TOTALS: & 593.58 & \\
\hline
\end{tabular}


WHC-SD-WM-T1-711

Revision 0

\section{APPENDIX I}

CALCULATION OF BOUNDING CUMULATIVE PUBLIC DOSE (PERSON-REM) FOR SINGLE-SHELL TANKS 
WHC-SD-WM-TI-711

Revision 0

This page intentionally left blank. 
WHC-SD-WM-TI-711

Revision 0

\section{APPENDIX I}

\section{CALCULATION OF BOUNDING CUMULATIVE PUBLIC DOSE (PERSON-REM) FOR SINGLE-SHELL TANKS}

Internal Dose. Bounding cumulative public internal dose (person-rem) from current levels of SST waste is given as follows:

Person-rem/yr $=$ ALIs $x$ EF/year $\times$ DF $x$ UF $\times 5$ person-rem/ALI

Where: ALIs are the bounding number of ALIs currently stored in SSTs

EF is the bounding escape fraction of ALIs per year from the disposal site

DF is the bounding environmental dispersion factor of the ALIs that escape the disposal site

UF is the bounding human uptake fraction of the ALls that are dispersed in the environment.

The bounding number of mobile and nonmobile ALIs (Appendix E) are as follows:

Total mobile ALIs $=5.57 \mathrm{E} 7$

Total nonmobile ALIs $=8.0 \mathrm{E} 12$

The value of EF for both the mobile and nonmobile case can be assumed to be bounded by $1.0 \mathrm{E}-4 /$ year, which means that in 10,000 years all the radioactivity in SSTs has escaped to the environment. This is based on the 10,000-year period cited by EPA relative to the performance of radioactive waste disposal sites. A value of $1.0 \mathrm{E}-4 /$ year is admittedly overly conservative. It is realized that this rate would not necessarily be constant, but it is so conservative that a rate exceeding this, over any increment of time, would be very unlikely.

The equilibrium values of the dispersion factors are difficult to estimate. As radioactive materials leak from the disposal system and enter the dose pathway, radioactive materials also leave the dose pathway. For example, as ${ }^{239} \mathrm{Pu}$ is being resuspended and deposited on occupied areas, it is also being resuspended and blowing away from occupied areas. It will be conservatively assumed that the equilibrium conditions are such that the dispersion factors are simply equal to the volumetric or areal dispersion of the radioactive materials. Therefore, the values of DF are bounded by $1.7 \mathrm{E}-2$ in the groundwater case (mobile ALIs) and 2.3E-2 in the terrestrial case (nonmobile ALIs). These numbers are derived as follows. 
Groundwater DF: Assume that mobile ALIs leach out of the disposal site and reside in a lens of groundwater $1 \mathrm{~m}$ thick under the Hanford Site, which is assumed to be $1,500 \mathrm{~km}^{2}$. The dispersion factor, DF, can be conservatively taken as the ratio of the liquid waste volume in tanks and the volume of groundwater. The total tank liquid waste volume is given in Appendix $\mathrm{F}$ as $2.6 \mathrm{E} 4 \mathrm{~m}^{3}$. So:

Tank liquid volume/groundwater volume $=2.6 \mathrm{E} 4 \mathrm{~m}^{3} /\left(1 \mathrm{~m} \mathrm{x} 1.5 \mathrm{E} 6 \mathrm{~m}^{2}\right)=1.7 \mathrm{E}-2$

Terrestrial DF: The terrestrial value of the dispersion factor is bounded by the ratio of the areal extent of the tanks and the areal size of the land that the population resides on. That is, areal contamination brought to the surface of the disposal sites is diluted and dispersed, in accordance with Gaussian-type gradients. The areal extent of the single shell tank farms is estimated to be about $7.0 \mathrm{E} 4 \mathrm{~m}^{2}$ and the areal extent of the population is estimated to be about $3,000 \mathrm{~km}^{2}$ or $3.0 \mathrm{E} 6 \mathrm{~m}^{2}$.

$$
7.0 \mathrm{E} 4 \mathrm{~m}^{2} / 3.0 \mathrm{E} 6 \mathrm{~m}^{2}=2.3 \mathrm{E}-2
$$

The value of UF for the groundwater pathway is assumed to be bounded by 1.0E-3. That is, it is assumed that $1 / 1000$ of all the groundwater under the Hanford Site is actually consumed by humans each year via drinking water.

The value of UF for the terrestrial pathway is assumed to be bounded by 1.0E-8. This is based on the resuspension factor for radioactivity (Boothe 1979). It is assumed that the principal route of exposure is through inhalation of resuspended radioactivity. Assuming a resuspension factor as high as 1.0E-8 ensures that this is true.

The bounding cumulative public internal doses can now be calculated as follows:

Person-rem/year (groundwater) $=5.57 \mathrm{E} 7$ ALIs $\times 1.0 \mathrm{E}-4 /$ year $\times 1.7 \mathrm{E}-2 \times$ $1.0 \mathrm{E}-3 \times 5$ person-rem/ALI $=0.47$ person-rem/year

Person-rem/year (terrestrial) $=8.0 \mathrm{E} 12$ ALIs $\mathrm{x}$ 1.0E-4/year $\mathrm{x}$ 2.3E-2 $\mathrm{x}$ $1.0 \mathrm{E}-8 \times 5 \mathrm{man}-\mathrm{rem} / \mathrm{ALI}=0.92$ person-rem/year

External Dose. Using the dose factor in Appendix A and assuming that 1.0E-4 times the long-term gamma inventory $\left({ }^{126} \mathrm{Sn}\right)$ resides in the near-soil at any one time, the annual external radiation dose per person is given as follows:

$\left(5.0 \mathrm{E}-2 \mathrm{rem}-\mathrm{km}^{2} /\right.$ year-Ci $\left.\times 1.0 \mathrm{E}-4 \times 375 \mathrm{Ci}\right) / 3,000 \mathrm{~km}^{2}=6.25 \mathrm{E}-7 \mathrm{rem} /$ year

Assuming that 100 percent of the population is exposed as follows:

Person-rem/year $($ external $)=6.25 \mathrm{E}-7 \mathrm{rem} /$ year $\times 200,000$ persons $=0.1$ 


\section{Revision 0}

The total bounding internal and external public cumulative dose can now be calculated as follows:

Total Bounding Cumulative Dose $=0.47+0.92+0.1=1.49$ personrem/year

The above person-rem/year values are based on very conservative estimates of the number of ALIs in SSTs and on other assumptions that are considered bounding and conservative. The values can be compared with background radiation, which is 60,000 man-rem/year for the 200,000 people that currently reside near the Hanford Site. 
WHC-SD-WM-TI-711

Revision 0

This page intentionally left blank. 
WHC-SD-WM-TI-711

Revision 0

APPENDIX $\mathbf{J}$

SINGLE-SHELL TANK REMEDIATION

AND HAZARD REDUCTION 
WHC-SD-WM-TI-711

Revision 0

This page intentionally left blank. 
APPENDIX $J$

SINGLE-SHELL TANK REMEDIATION AND HAZARD REDUCTION

TANKS IN DESCENDING OROER OF HAZARD (NONMOBLLE ALI'S)

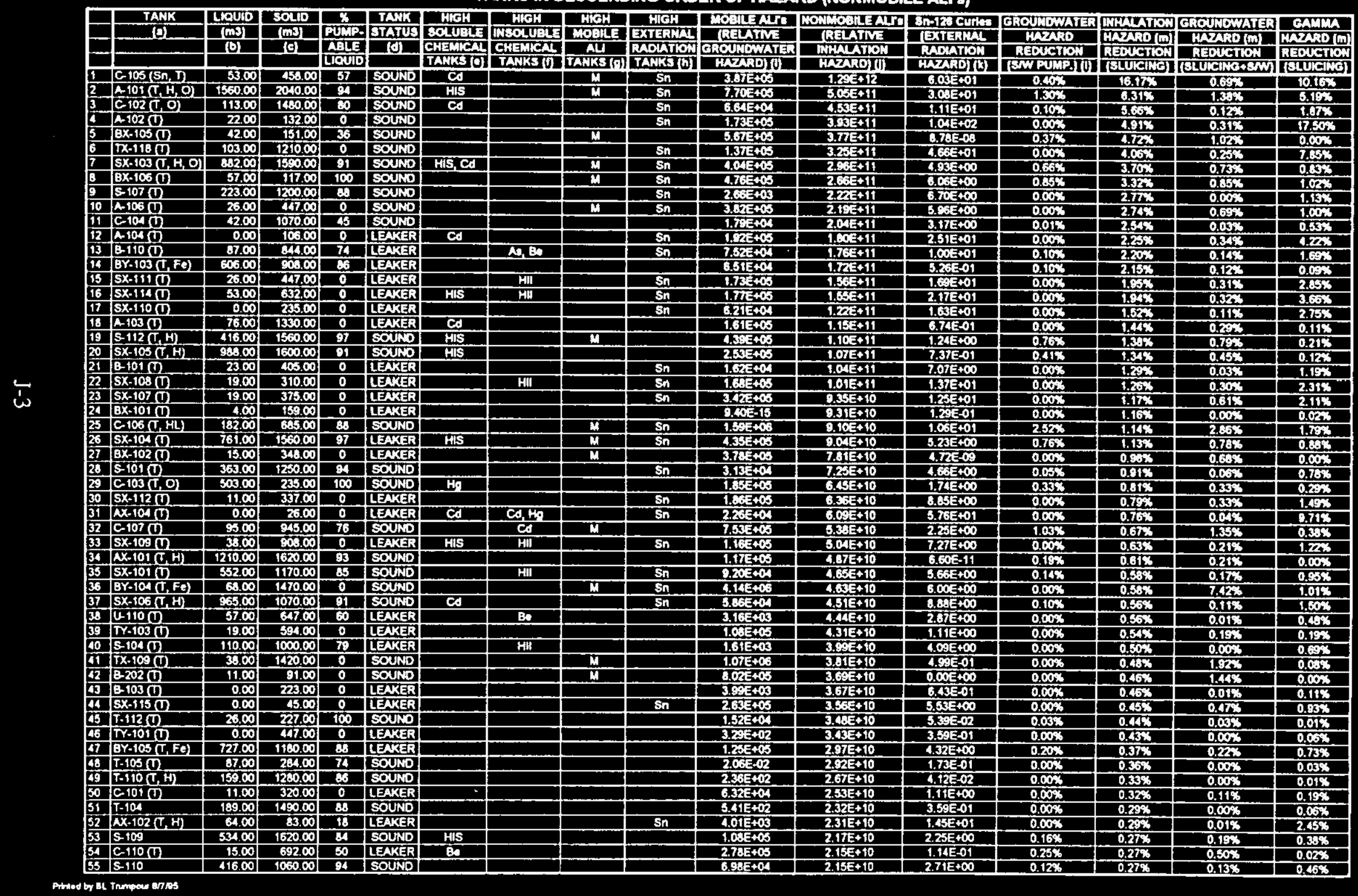




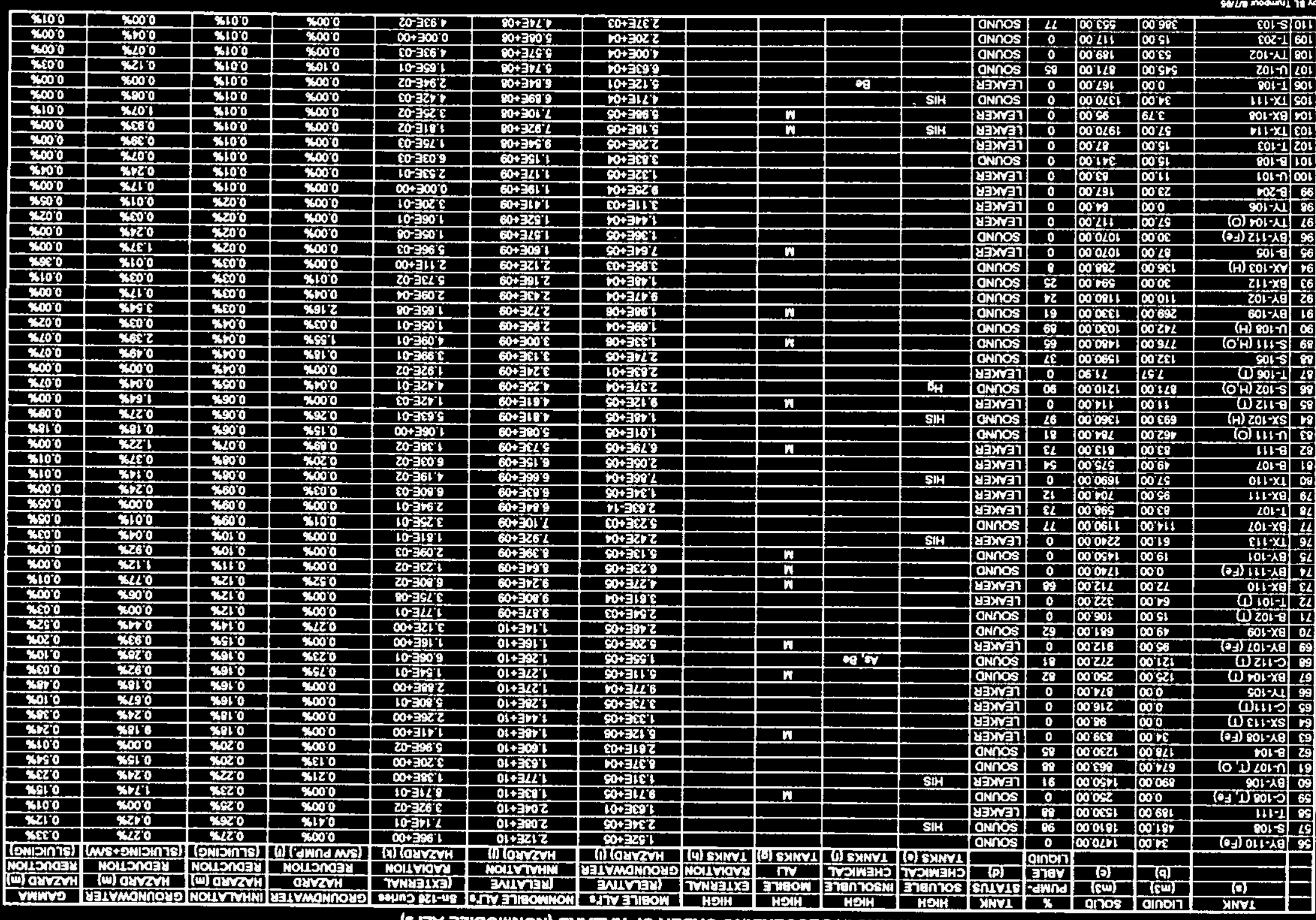




\section{SINGLE-SHELL TANK REMEDIATION AND HAZARD REDUCTION \\ TANKS IN DESCENDINC ORDER OF HAZARD (NONMOBILE ALP'S)}

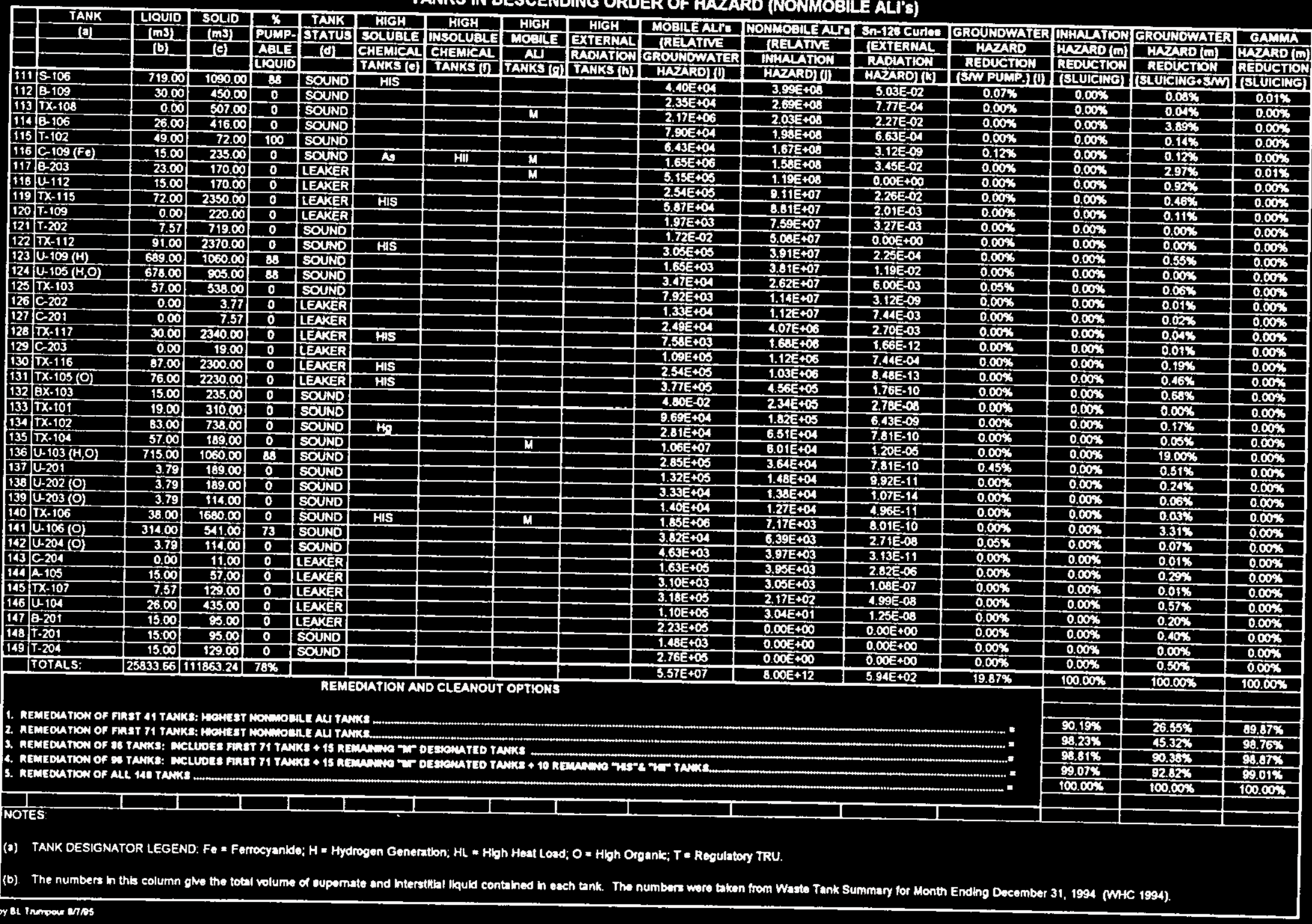




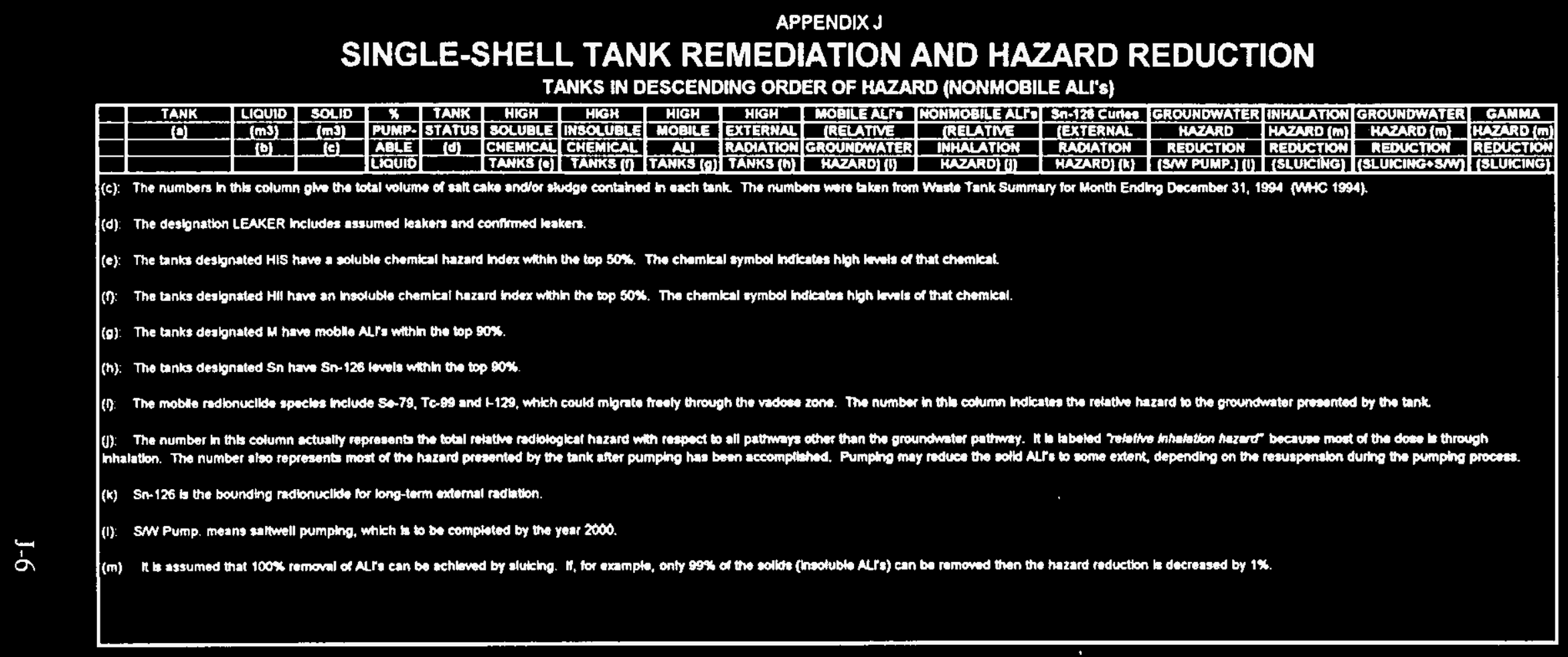

